\title{
Development and Documentation of Spatial Data Bases for the Lake Tahoe Basin, California and Nevada
}

UNITED STATES GEOLOGICAL SURVEY

Water-Resources Investigations Report 93-4182

Prepared in cooperation with the TAHOE REGIONAL PLANNING AGENCY
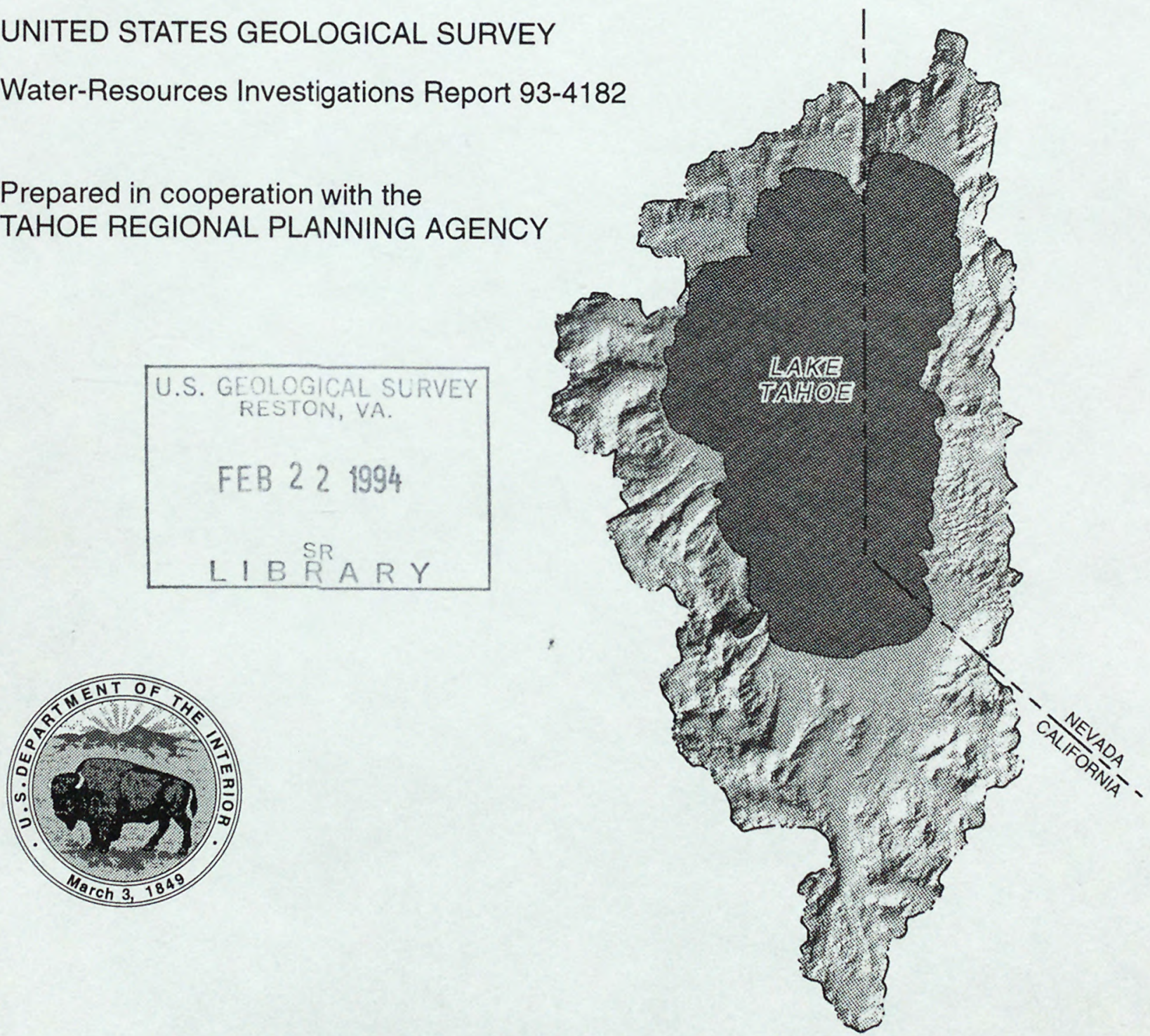


\section{Development and Documentation of Spatial Data Bases for the Lake Tahoe Basin, California and Nevada}

By Kenn D. Cartier, Lorri A. Peltz, and J. LaRue Smith

U.S. GEOLOGICAL SURVEY

Water-Resources Investigations Report 93-4182

Prepared in cooperation with the

TAHOE REGIONAL PLANNING AGENCY

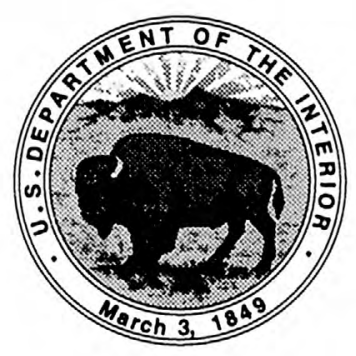

Carson City, Nevada 


\title{
U.S. DEPARTMENT OF THE INTERIOR BRUCE BABBITT, Secretary
}

\author{
U.S. GEOLOGICAL SURVEY \\ ROBERT M. HIRSCH, Acting Director
}

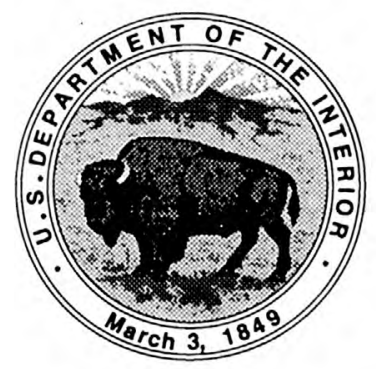

Any use of trade names in this publication is for descriptive purposes only and does not imply endorsement by the U.S. Government.

For additional information write to:

District Chief

U.S. Geological Survey 333 West Nye Lane, Room 203

Carson City, NV 89706-0866
Copies of this report can be purchased from:

\section{U.S. Geological Survey} Earth Science Information Center Open-File Reports Section Box 25286, MS 517 Denver Federal Center Denver, CO 80225-0046 


\section{CONTENTS}

Abstract

Introduction

Purpose and Scope.

4

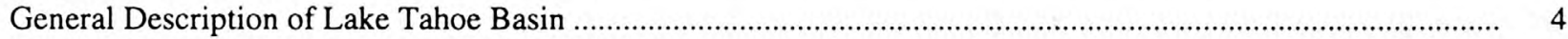

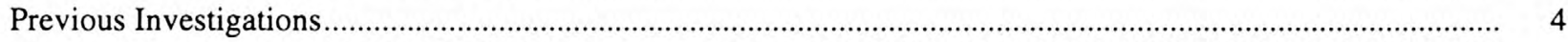

Description of Geographic Information Systems and Computer Equipment ......................................................

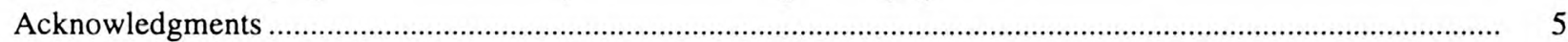

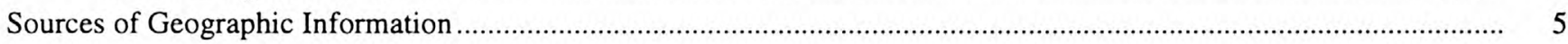

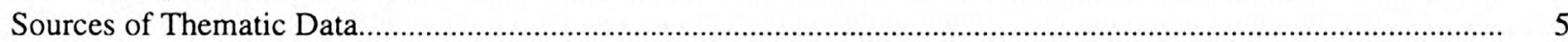

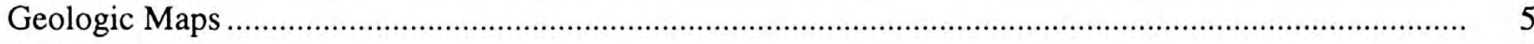

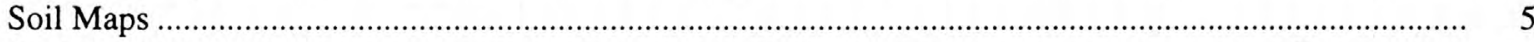

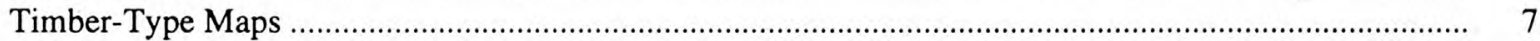

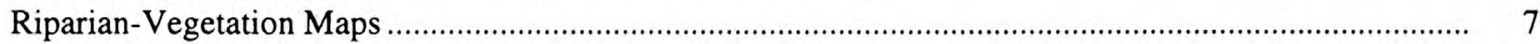

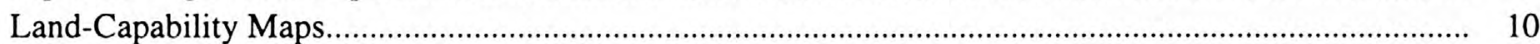

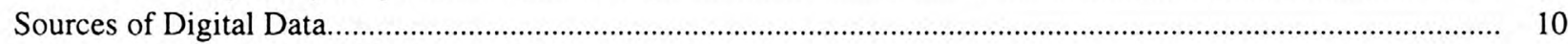

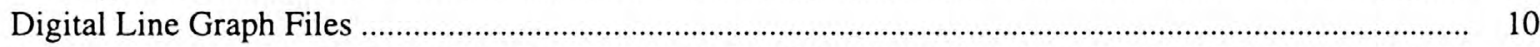

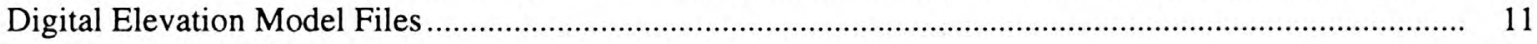

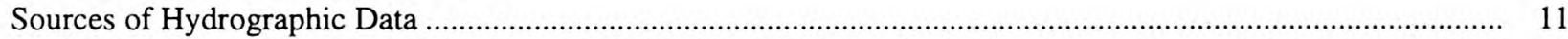

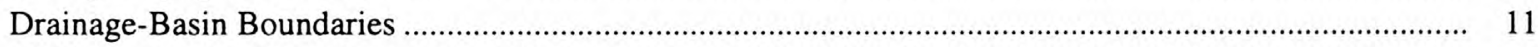

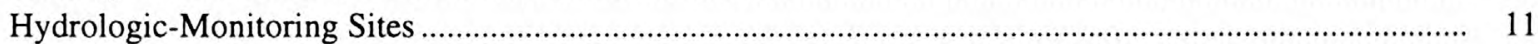

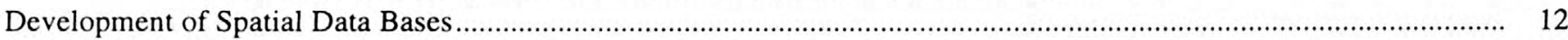

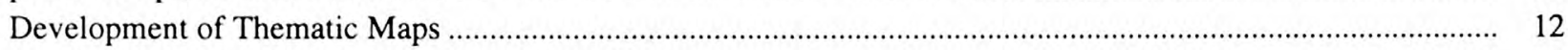

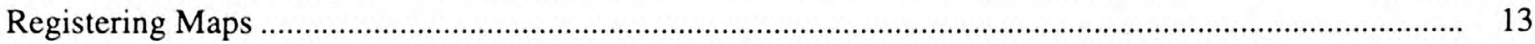

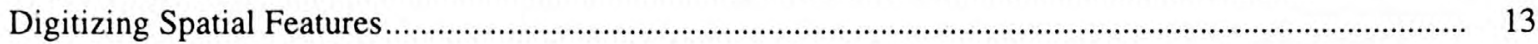

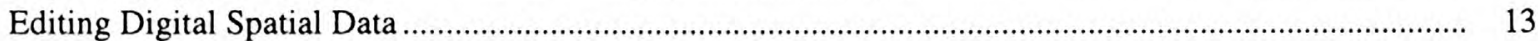

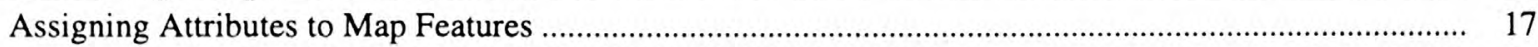

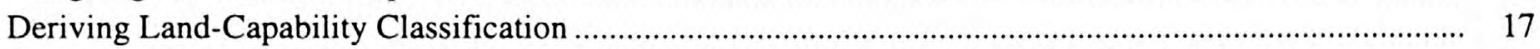

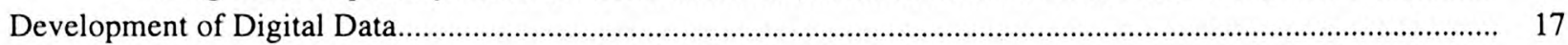

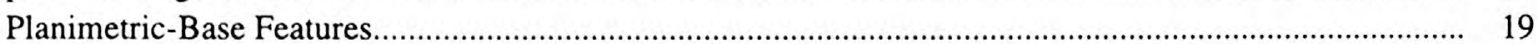

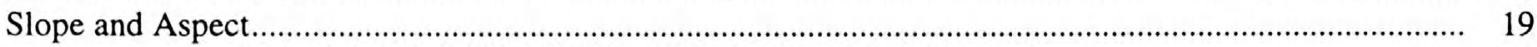

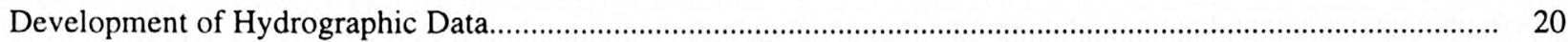

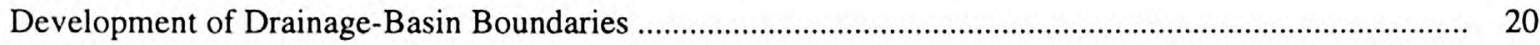

Development of Hydrologic-Monitoring Sites ........................................................................................... 20

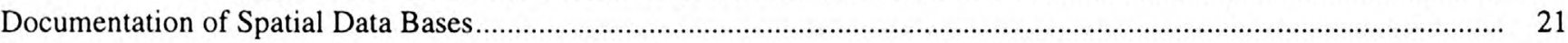

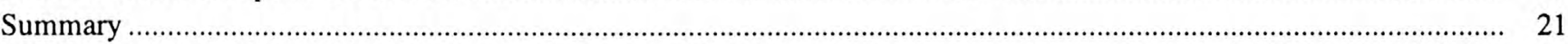

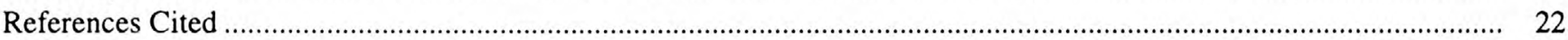

\section{FIGURES}

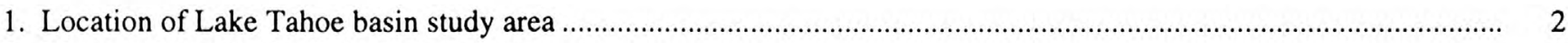

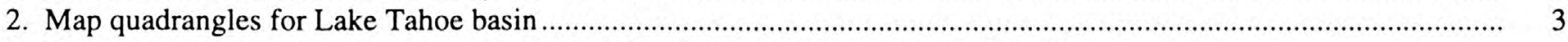

3. Examples of thematic source maps for part of South Lake Tahoe map quadrangle ............................................ 6

4. Index map indicating best available geologic and related maps for Lake Tahoe basin .............................................. 8

5. Example plots of digital maps developed from thematic source maps for part of South Lake Tahoe map quadrangle......

6. Example plots of spatial data bases derived from Digital Line Graph and Digital Elevation Model files 
TABLES

1. Geologic and related maps used as source material for compiling geology of Lake Tahoe basin...................... 7

2. Classification categories used by U.S. Forest Service on timber-type maps .................................................. 9

3. Classification categories used by U.S. Forest Service on riparian-vegetation maps........................................ 10

4. Categories used in land-capability classification ......................................................................................... 11

5. Map quadrangles used as source maps for Digital Line Graph and Digital Elevation Model computer files ...... 12

6. Spatial data bases developed from thematic maps, digital data, and hydrographic data................................. 14

7. Cross-reference for land-capability types and U.S. Soil Conservation Service soil units ............................... 17

8-19. Summary documentation for spatial data bases in Tahoe Environmental Geographic Information System:

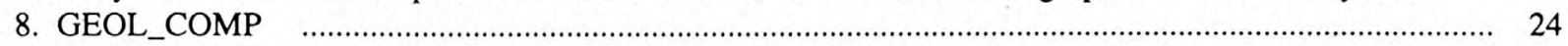

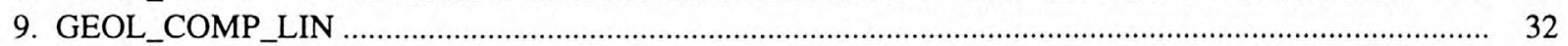

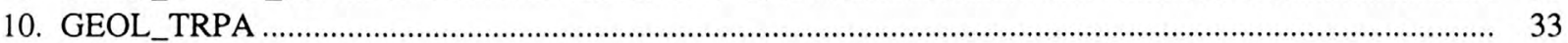

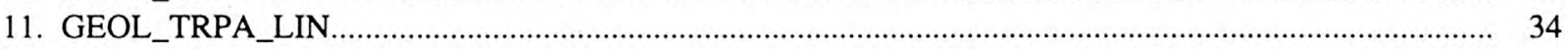

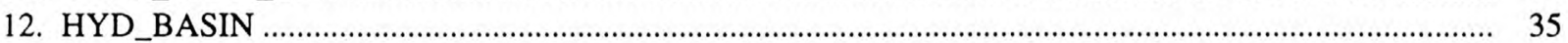

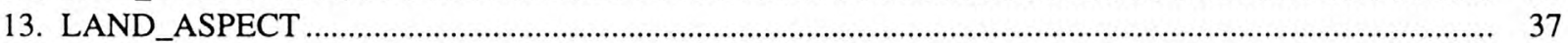

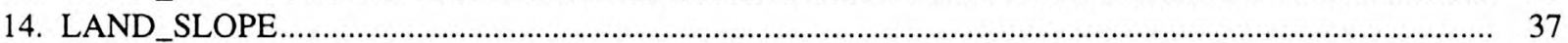

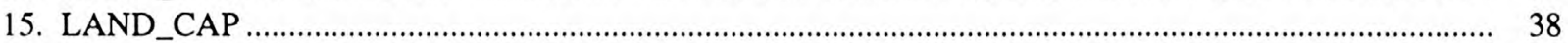

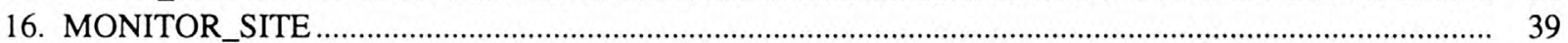

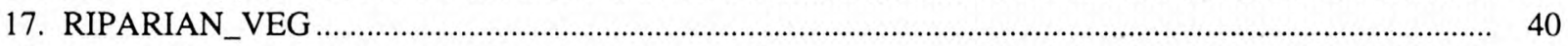

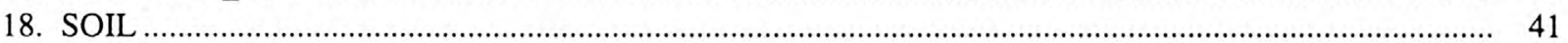

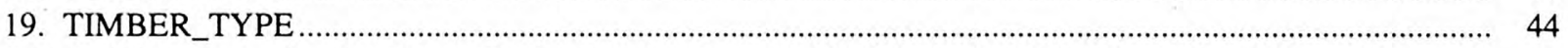

20. Detailed documentation for Tahoe Environmental Geographic Information System coverages....................... 50 
CONVERSION FACTORS, VERTICAL DATUM, AND ACRONYMS

\begin{tabular}{rll}
\hline Multiply & By & To obtain \\
\hline & & \\
meter & 3.281 & foot \\
square meter & 10.76 & square foot \\
kilometer & 0.6214 & mile \\
square kilometer & 0.3861 & square mile \\
hectare & 2.471 & acre \\
\hline
\end{tabular}

Sea Level: In this report, "sea level" refers to the National Geodetic Vertical Datum of 1929 (NGVD of 1929, formerly called Sea-Level Datum of 1929), which is derived from a general adjustment of the first-order leveling networks of the United States and Canada.
AML Arc Macro Language
CDMG California Division of Mining and Geology
DEM Digitial Elevation Model
DLG Digital Line Graph
ELAS Science and Technology Laboratory Applications Software, developed by National Aeronautics and Space Administration
ESRI Environmental Systems Research Institute
GIS Geographic information system
LWQCB Lahontan Water Quality Control Board
NASA National Aeronautics and Space Administration
NDEP Nevada Division of Environmental Protection
PLSS Public Land Survey System, often referred to as township, range, and section boundaries
RMS Root mean square, a statistical estimate of error
SCS U.S. Soil Conservation Service
SVF Single-variable file
TEGIS Tahoe Environmental Geographic Information System
TRPA Tahoe Regional Planning Agency
USFS U.S. Forest Service
USGS U.S. Geological Survey
UTM Universal Transverse Mercator map-projection and coordinate system 



\title{
Development and Documentation of Spatial Data Bases for the Lake Tahoe Basin, California and Nevada
}

\author{
By Kenn D. Cartier, Lorri A. Peltz, and J. LaRue Smith
}

\begin{abstract}
A set of spatial data bases consisting of natural-resources and planimetric-base layers has been developed and documented for the Lake Tahoe basin, California and Nevada. The data bases, in the form of geographic information system coverages, include surface geology, soils, timber type, riparian vegetation, land capability, stream channels, water bodies, roads, political boundaries, the Lake Tahoe basin boundary, slope, aspect, drainage-basin boundaries, and hydrologic-monitoring sites. The data bases were developed from existing thematic maps, digital data, and hydrographic records. Data were compiled from maps and records of Federal, State, and local agencies. The scale of source materials ranged from $1: 24,000$ to $1: 125,000$ and their release dates, from 1964 to 1989. Documentation and summary information are included for each spatial data base.
\end{abstract}

\section{INTRODUCTION}

The Lake Tahoe basin encompasses an area of 1,310 square kilometers of alpine and subalpine land within the Sierra Nevada of California and Nevada (fig. 1). The area is renowned for the natural beauty of its mountain ranges and lakes, particularly Lake Tahoe. As a result of public interest and concern for preservation of the natural resources of the basin, various Federal, State, and local agencies collect environmental data regarding the water and land resources of the basin. In the mid-1980's, many of these agencies recognized the need to develop a data-base management system for resources planning and for analysis of the land-use and environmental information collected in the basin.

In recent years, people have been increasingly concerned about the effects of development on the water clarity and quality of Lake Tahoe. Resources assessment, basic research, and land and resources management in the Lake Tahoe basin have been hampered by the lack of a consistent and common data base for the basin. In the past, the environmental data for the basin were stored in a large variety of formats by individual agencies in numerous locations with differing reporting conventions and standards. None of these agencies could efficiently compile, analyze, describe, and display geographically referenced environmental data.

In 1988 the U.S. Geological Survey (USGS) and the Tahoe Regional Planning Agency (TRPA) began a cooperative project to develop a geographic information system (GIS) to meet the data-base needs for the Lake Tahoe basin. TRPA is a joint California-Nevada agency that manages and analyzes much of the landuse and environmental data collected in the basin. The U.S. Forest Service (USFS) and the U.S. Soil Conservation Service (SCS) also informally participated in the cooperative efforts. The resulting product is referred to as the Tahoe Environmental Geographic Information System (TEGIS).

The goals of the TEGIS project were (1) to develop a set of spatial data bases of natural-resources information for the Lake Tahoe basin and (2) to develop efficient techniques for creating spatial data bases. (In this report, the term "data base" refers to a set of information stored in digital form on a computer. A data base consists of a single layer, or type of information, such as vegetation or soils. When stored in a 


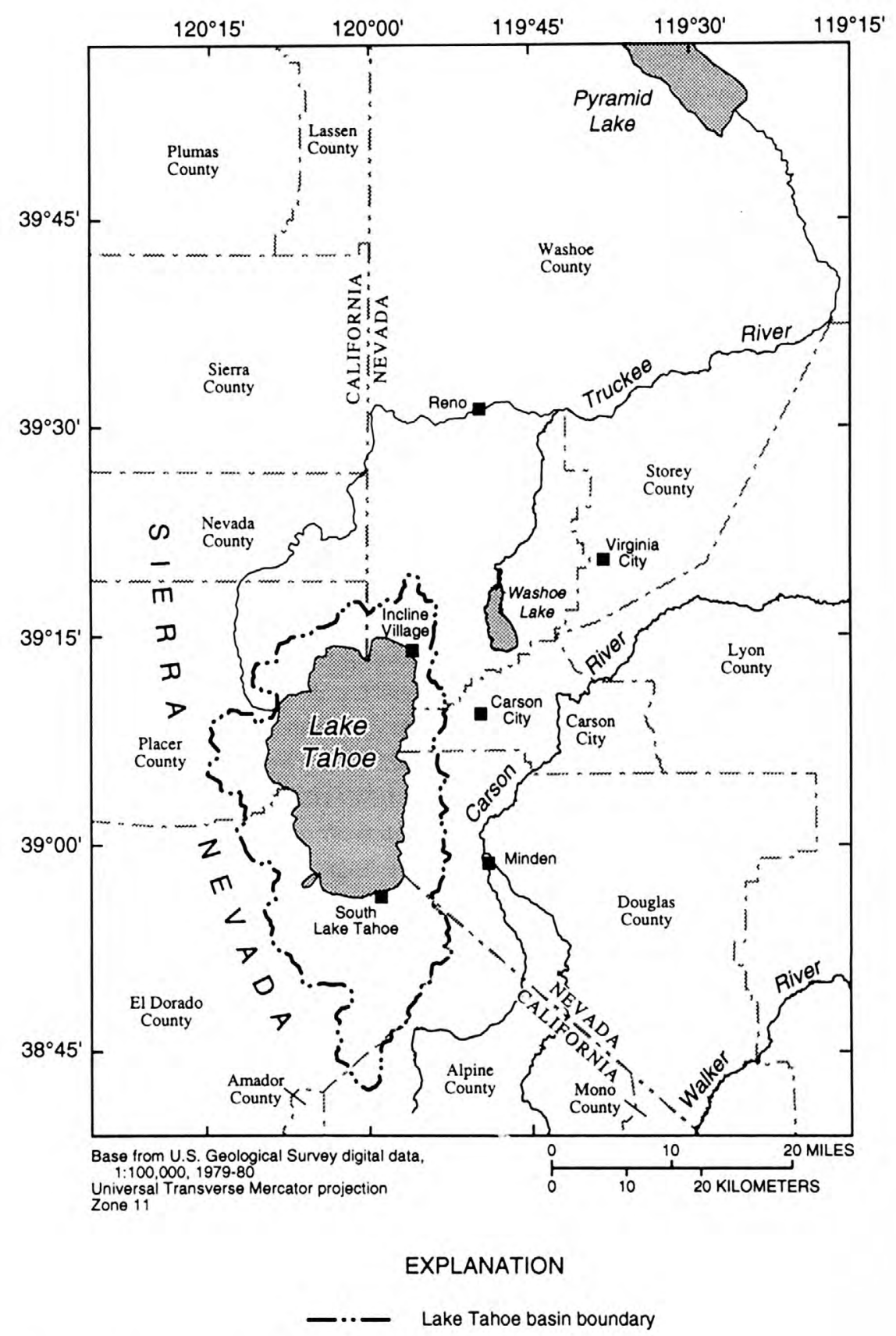

Figure 1. Location of Lake Tahoe basin study area.

GIS, each layer typically is referred to as a coverage. A coverage consists of attributes, or information, that relate to the Earth's surface by their spatial coordinates. In this report, the term "coverage" refers to a spatial data base that is organized into a specific group of files and directories.)
The TEGIS project was limited in area to the 16 USGS 7.5-minute-series quadrangles encompassing the Lake Tahoe basin (fig. 2). (Henceforth in this report, the term "map quadrangle" refers to the area covered by a USGS 1:24,000-scale, 7.5-minute-series topographic map.) 


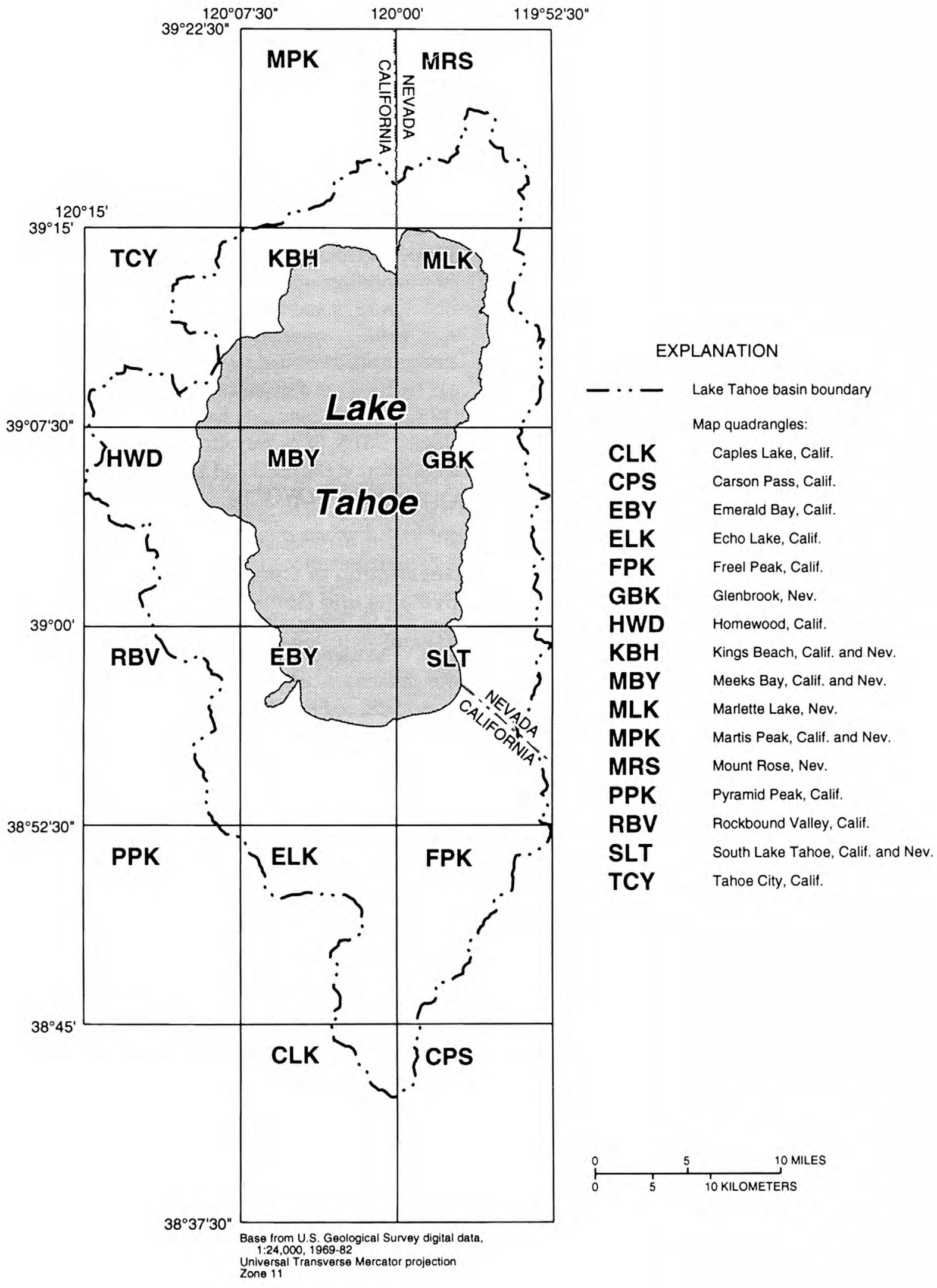

Figure 2. Index of 1:24,000-scale map quadrangles for Lake Tahoe basin. 


\section{Purpose and Scope}

This report documents (1) the sources of data in the spatial data bases, (2) the methods used to develop the TEGIS coverages, and (3) the contents of the coverages in the TEGIS data base. The report documents the 22 coverages representing the Lake Tahoe basin that were created for the TEGIS project. The report contains descriptions of the data sources, a discussion of data-base creation and editing, and statistical summaries of the spatial data bases.

The natural-resources layers include geology, soils, timber type, riparian vegetation, land use, stream channels, water bodies, the Lake Tahoe basin boundary, slope, aspect, drainage-basin boundaries, and hydrologic- monitoring sites.

The coverages were compiled from the largest scale and most recent maps and digital data files that were available for each data layer. Because the data were compiled from a variety of sources, it was not possible to create all coverages with a consistent map scale or resolution. Map scales ranged from 1:24,000 to $1: 125,000$. Release dates for the maps ranged from 1964 to 1989.

\section{General Description of Lake Tahoe Basin}

Lake Tahoe and the Lake Tahoe basin are drained by the Truckee River, which flows into Pyramid Lake in northwestern Nevada. Lake Tahoe has a surface area of 500 square kilometers and is renowned for its strikingly blue color and water clarity.

The geology of the Lake Tahoe basin is dominated by igneous rock, chiefly granodiorite, andesite, and granite. The basin was glaciated during the Pleistocene epoch and contains spectacular landforms produced by glacial erosion and deposition.

The Lake Tahoe basin encompasses parts of six counties: Alpine, El Dorado, and Placer Counties in California and Carson City, Douglas, and Washoe Counties in Nevada. Sixteen USGS 1:24,000-scale map quadrangles cover the basin: Caples Lake, Calif.; Carson Pass, Calif.; Echo Lake, Calif.; Emerald Bay, Calif.; Freel Peak, Calif.; Glenbrook, Nev.; Homewood, Calif.; Kings Beach, Calif. and Nev.; Marlette Lake, Nev.; Martis Peak, Calif. and Nev.; Meeks Bay, Calif. and Nev.; Mount Rose, Nev.; Pyramid Peak, Calif;; Rockbound Valley, Calif.; South Lake Tahoe, Calif. and Nev.; and Tahoe City, Calif. (fig. 2).
Previous Investigations

The natural resources of the Lake Tahoe basin have been extensively mapped and studied by numerous agencies and individuals. The geology of the basin was mapped mainly by Thompson and White (1964), Burnett (1971), Bonham and Burnett (1976), Loomis (1981), Armin and John (1983), Armin and others (1984), and Grose $(1985,1986)$. The soils were mapped by the SCS and USFS (Rogers, 1974). The forest and riparian vegetation were mapped by the USFS in 1979 and 1988, respectively (U.S. Forest Service, written communs., 1990, 1991). Land-capability classes were identified by TRPA (Bailey, 1974). Drainage basins were delineated by Jorgensen and others (1978). Hydrologic data have been collected by the USGS, USFS, SCS, Nevada Division of Environmental Protection (NDEP), and Lahontan Water Quality Control Board (LWQCB).

\section{Description of Geographic Information Systems and Computer Equipment}

The spatial data bases developed for this study were created by using ARC/INFO software, a vectorbased GIS, and ELAS software, a raster-based GIS. A GIS is an "organized collection of computer hardware, software, geographic data, and personnel designed to efficiently capture, store, update, manipulate, analyze, and display all forms of geographically referenced information" (Environmental Systems Research Institute, 1989). A vector-based GIS stores data or features as points, lines, or polygons that are defined by a set of Cartesian coordinates. Each feature in a vector layer may have many attributes. A raster-based GIS stores data as a regular array of cells. Each cell in a raster layer has a single value. All spatial data bases developed for this study were stored in final form as

ARC/INFO coverages.

The ARC/INFO software was installed on Prime minicomputers and Data General Aviion workstations in the USGS office in Carson City, Nev. ELAS software was installed on the Prime minicomputers. Some maps were digitized manually on a Calcomp 9100 digitizing table connected to the Prime minicomputers. Other maps were scanned and vectorized using a Tektronix 4991 electronic scanner and TekScan software on a Tektronix 4325 workstation at the USGS Regional GIS Laboratory in Menlo Park, Calif. 


\section{Acknowledgments}

The authors acknowledge Elizabeth A. Frick of the USGS for establishing the goals of the project and for doing the initial work. Data were provided by the TRPA, USFS, SCS, NDEP, and LWQCB. The authors thank H.K. Berger of the TRPA, Joseph Oden and Karen Hoffman of the USFS, and Michael Whiting of the SCS. The authors also acknowledge the Comprehensive Planning Department of Washoe County, Nev., for assistance in data collection during the early phases of the project.

\section{SOURCES OF GEOGRAPHIC INFORMATION}

Spatial data bases for the TEGIS project were created from three general sources of geographic information: thematic maps, digital maps, and hydrographic data records. Thematic maps were compiled from Federal and State agencies. Digital maps were obtained from the Earth Science Information Center of the USGS. Hydrographic data were compiled by Federal, State, and other agencies.

\section{Sources of Thematic Data}

Thematic maps were obtained for five naturalresources layers: geology, soils, timber type, riparian vegetation, and land capability. The largest scale maps available for each thematic layer were used. When available, mylar maps were used in preference to paper maps to minimize media distortion. When available, thematic separate maps were used to simplify the digitizing process.

Examples from thematic source maps that were obtained from the USFS and SCS are shown in figure 3. The examples depict part of the South Lake Tahoe map quadrangle. Each of these maps contains hundreds of individual map polygons, or discrete areal features, and is representative of the complexity of natural-resources maps for the basin. Thematic composite maps (fig. $3 B$ ) contain many extraneous features, such as place names and political boundaries. This extraneous material was removed when the coverages were edited (fig. 5).

\section{Geologic Maps}

Geologic and related maps were available for the Lake Tahoe basin at map scales ranging from 1:24,000 to $1: 125,000$. Some areas of the basin were mapped at different scales. Information about these source maps, including map name, mapped area, author, scale, and form, is summarized in table 1.

The geology of the Lake Tahoe basin was mapped at a scale of 1:125,000 in 1968 in northern and southern halves, by R.A. Matthews and J.L. Burnett, respectively. This work was published in a report by Burnett (1971). In 1974, the TRPA compiled a naturalhazards map of the basin from the 1:125,000-scale geologic mapping and other sources. This thematic information was recompiled at a scale of 1:24,000. For this study, mylar copies of these unpublished map sheets were obtained from the TRPA (H.K. Berger, written commun., 1990).

Geologic maps at 1:24,000 scale were available for only 3 of the 16 map quadrangles for the Lake Tahoe basin (Bonham and Burnett, 1976; Grose, 1985, 1986). Geologic maps at 1:62,500 scale were used for seven other map quadrangles (Thompson and White, 1964; Loomis, 1981; Armin and John, 1983; Armin and others, 1984). For the remaining six map quadrangles, the geologic data from the natural-hazards map were used. A map of the distribution of these largest scale source maps is shown in figure 4 . With one exception, these source maps were available on mylar; the mapped linear geologic features for the Freel Peak quadrangle were available only on paper. Due to the variety of map scales and authors, it was beyond the scope of this study to resolve all the differences in mapped geology. The location or classification of geologic features does not match across many of the borders between adjacent maps. These discrepancies, inherited from the source maps, remain in the composite coverages of geology.

\section{Soil Maps}

Thematic maps of soil units were obtained from the published soil survey of the Lake Tahoe basin area (Rogers, 1974). The 1:24,000-scale maps were developed cooperatively by the SCS and USFS and include 49 separate mapping units. 


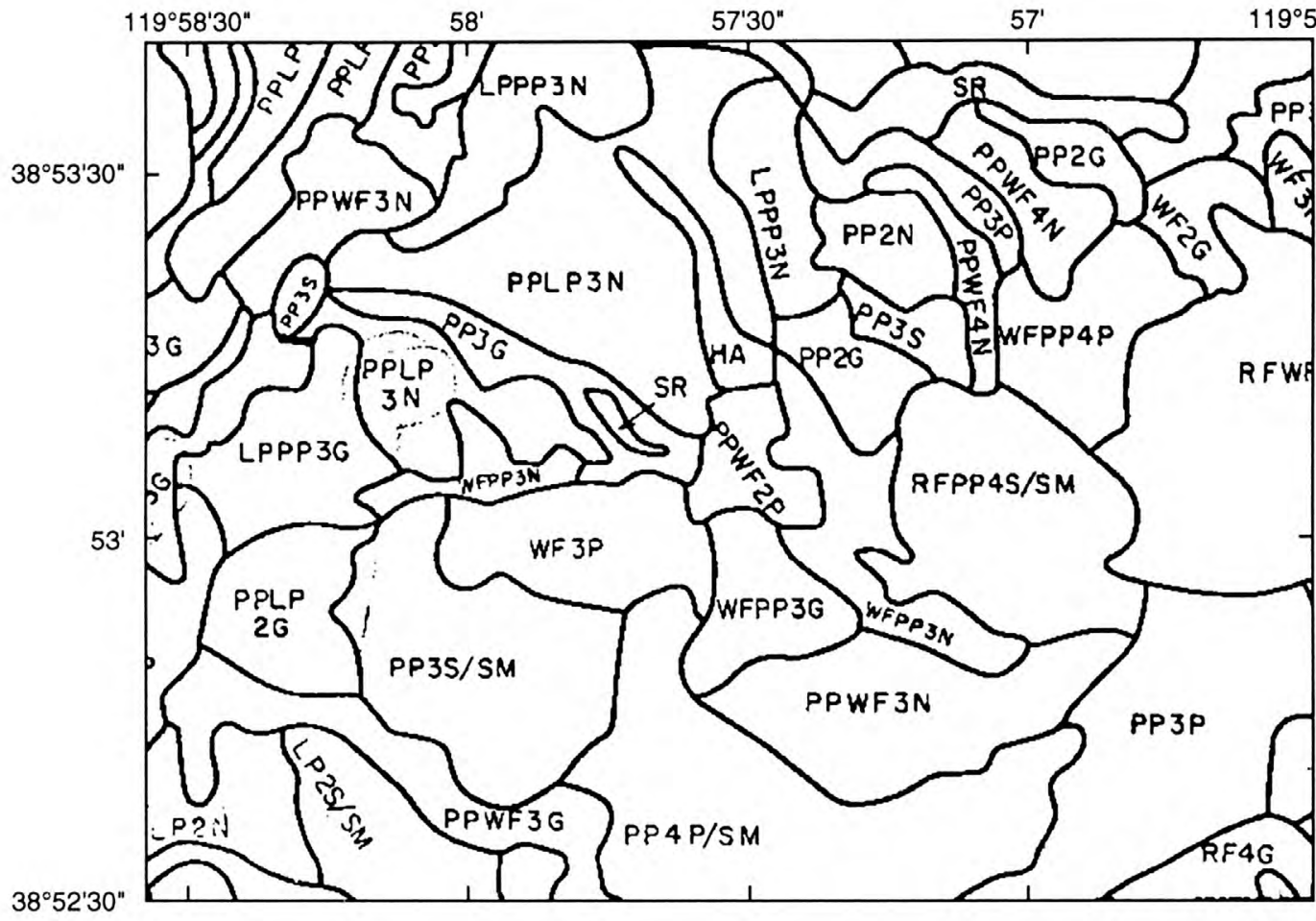

$\boldsymbol{A}$

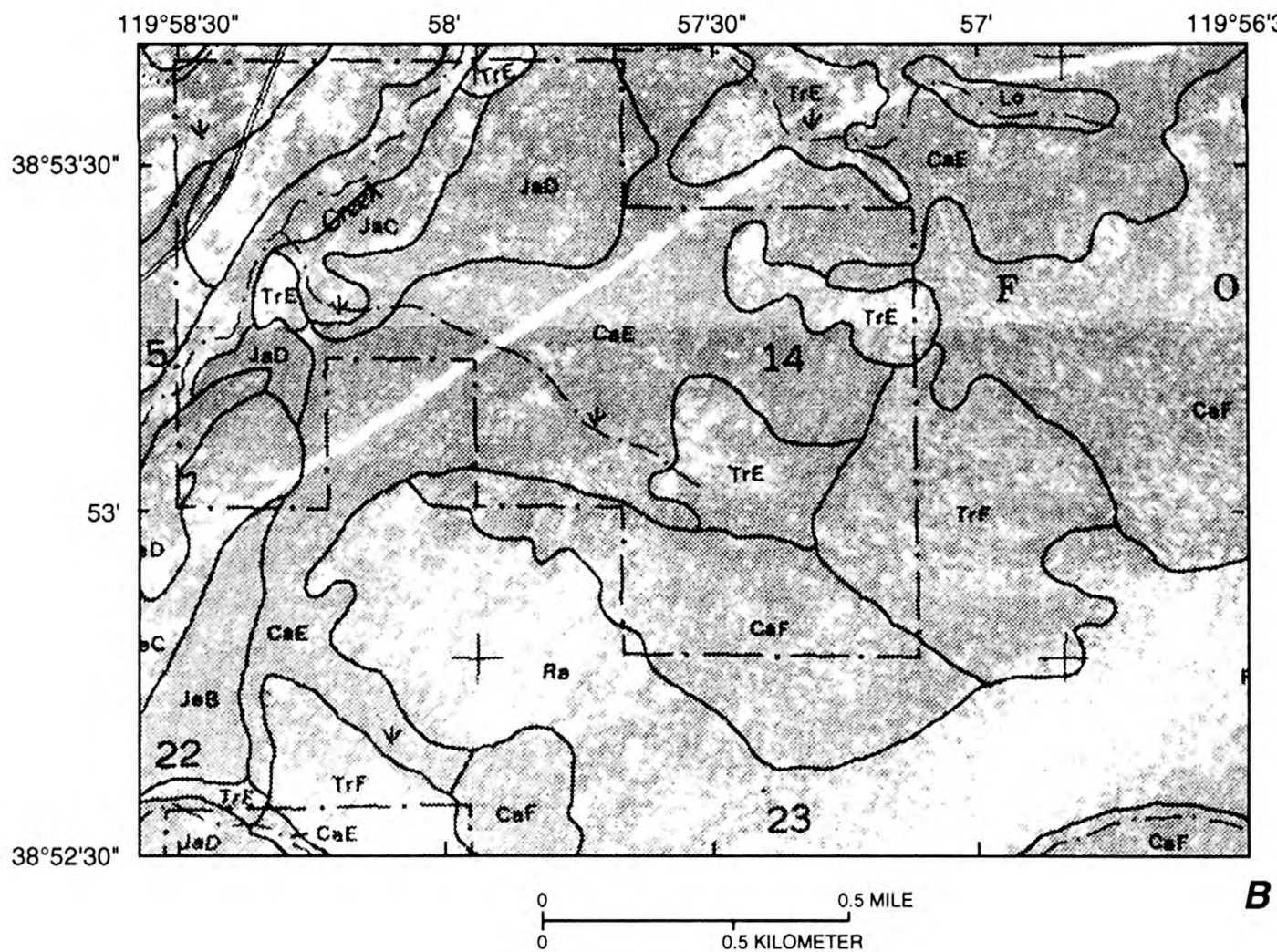

Figure 3. Examples of thematic source maps for part of South Lake Tahoe map quadrangle, showing original linework and extraneous features such as boundaries, labeling, and other notations to be excluded from the digital products. A, U.S. Forest Service timber-type map. B, U.S. Soil Conservation Service soil-survey map. 
Table 1. Geologic and related maps used as source material for compiling geology of Lake Tahoe basin (Map identifier: Code used in figure 4 to show area for which map was main or only source of information used in compiling geology. Corresponding USGS quadrangles: U.S. Geological Survey $7.5-$ or 15-minute-series topographic quadrangles that cover area of source map. do., ditto]

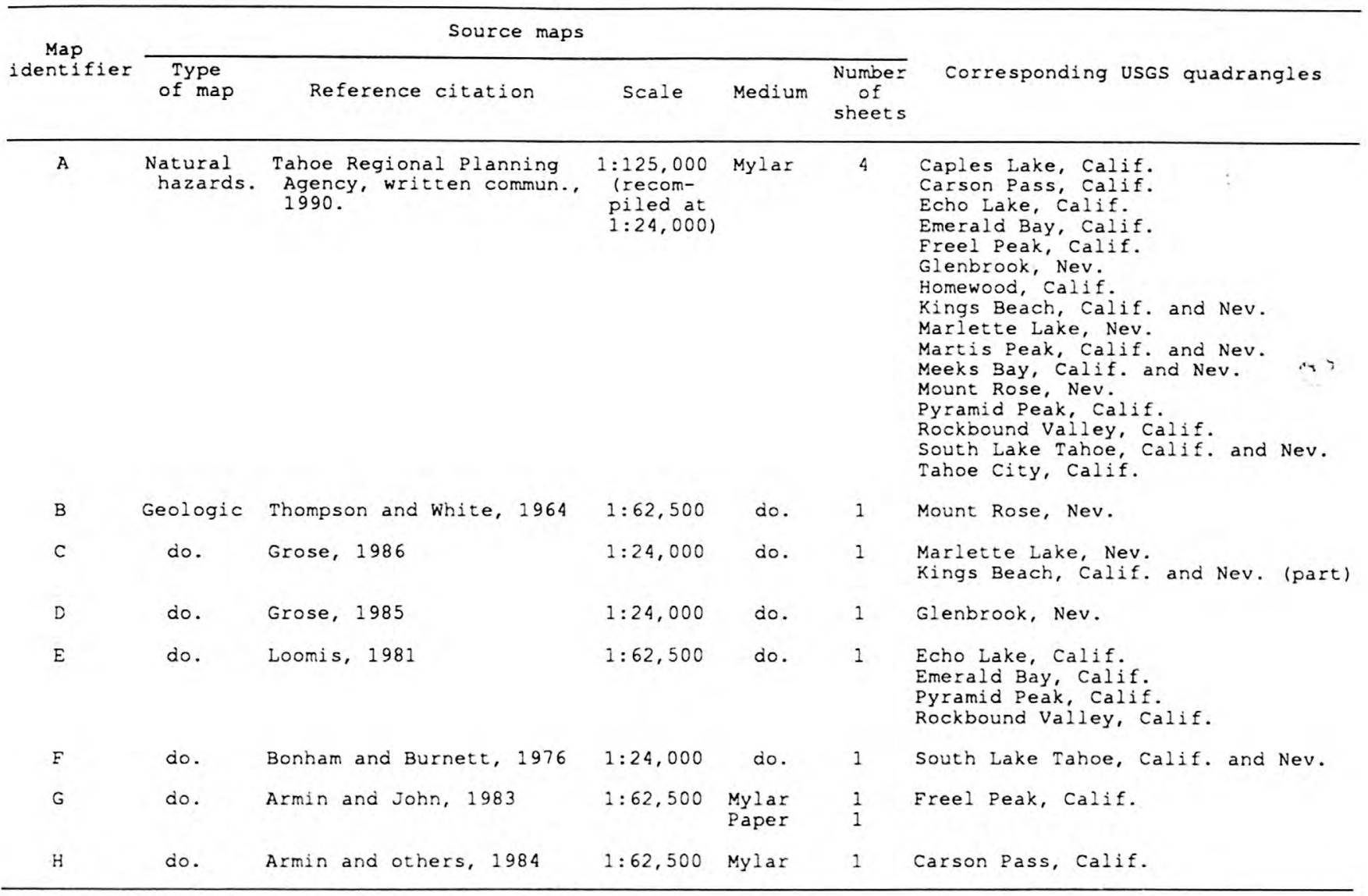

The SCS maps were available only as folded paper maps. The maps are composed of a black separate layer printed over a pale-green orthophotoquad background. The black separate layer contains thematic linework and labels as well as political borders, stream channels, and transportation and other features.

\section{Timber-Type Maps}

Timber-type units of the Lake Tahoe basin were mapped by the USFS on low-altitude aerial photographs taken in the summer of 1978 . The linework was transferred to 1:24,000-scale mylar maps (Joseph Oden, U.S. Forest Service, oral commun., 1991). These maps group timber-type units by major species, crown size, crown density, and understory vegetation. Categories and examples of timber-type unit symbols used by the USFS for the Lake Tahoe basin are shown in table 2. The timber-type units have a complex alpha- numeric symbol that groups mapped areas into three principal categories: (1) areas with woody vegetation, (2) areas with nonwoody and shrub vegetation, and

(3) nonvegetated areas.

Of the 16 timber-type maps, 13 were available from the USFS as thematic map separates. Composite maps with a pale-gray topographic background layer were obtained for the other three map quadrangles (Emerald Bay, Calif.; Homewood, Calif.; and Meeks Bay, Calif. and Nev.).

\section{Riparian-Vegetation Maps}

Riparian-vegetation units of the Lake Tahoe basin were mapped by the USFS on infrared, low-altitude aerial photographs taken in 1987. The linework was transferred to 1:24,000-scale mylar maps. By using categories shown in table 3 , the riparian vegetation was classified into plant communities of at least 


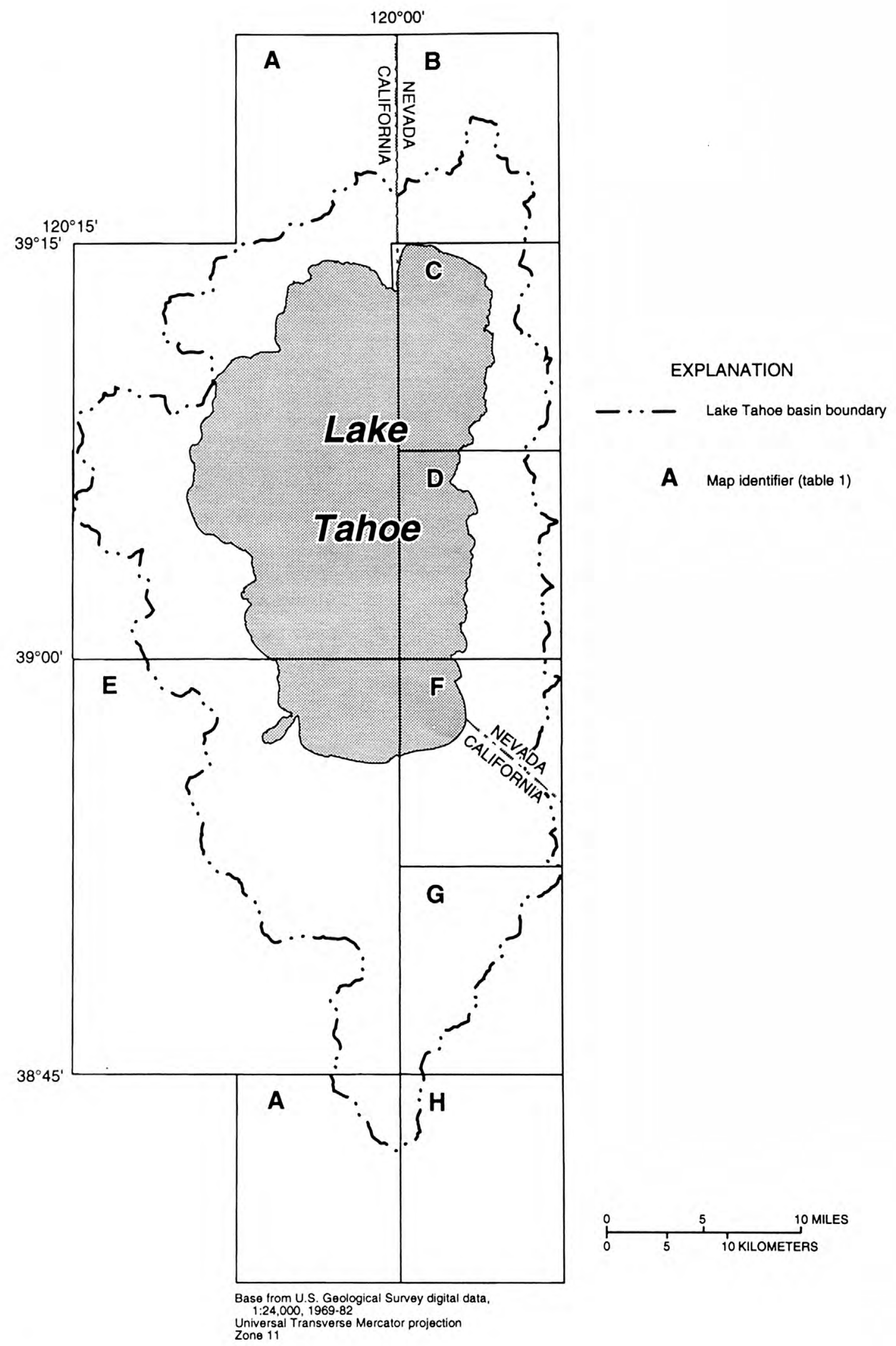

Figure 4. Index map indicating largest scale geologic and related maps for compiling geology of Lake Tahoe basin. Individual maps are listed in table 1 by map identifier. 
Table 2. Classification categories used by U.S. Forest Service on timber-type maps

[Information from Joseph Oden, U.S. Forest Service (written commun., 1992). Alphanumeric symbols used for timber-classification categories consist of as many as five components: First two letters designate primary species or nonvegetated area; next two letters denote secondary species; next number indicates crown size; next letter indicates crown density; and final two letters (preceded by "/") denote type of understory vegetation. For example, symbol PPWF 3 S/SM indicates primary species is ponderosa or Jeffrey pine, secondary species is white fir, crown diameter (primary species) is 13 to 24 feet, crown density (primary species) is 10 to 19 percent of area, and understory type is montane shrub]

\begin{tabular}{|c|c|c|}
\hline Classification basis & $\begin{array}{l}\text { Class } \\
\text { symbol }\end{array}$ & Class definition \\
\hline \multicolumn{3}{|c|}{ Woody-vegetation areas } \\
\hline $\begin{array}{l}\text { Primary and secondary } \\
\text { commercial conifers. }\end{array}$ & $\begin{array}{l}\text { LP } \\
\text { MH } \\
\text { PP } \\
\text { RF } \\
\text { SP } \\
\text { WE } \\
\text { WP }\end{array}$ & $\begin{array}{l}\text { Lodgepole pine. } \\
\text { Mountain hemlock. } \\
\text { Ponderosa or Jeffrey pine. } \\
\text { Red fir. } \\
\text { Sugar pine. } \\
\text { White fir. } \\
\text { Western white pine. }\end{array}$ \\
\hline $\begin{array}{l}\text { Primary and secondary } \\
\text { noncommercial conifers. }\end{array}$ & WB & Whitebark pine. \\
\hline $\begin{array}{l}\text { Primary and secondary } \\
\text { noncommercial hardwoods. }\end{array}$ & $\begin{array}{l}\mathrm{HA} \\
\mathrm{HX}\end{array}$ & $\begin{array}{l}\text { Aspen. } \\
\text { Miscellaneous hardwoods. }\end{array}$ \\
\hline $\begin{array}{l}\text { Crown size of primary } \\
\text { conifers or hardwoods. }\end{array}$ & $\begin{array}{l}1 \\
2 \\
3 \\
4 \\
5 \\
6\end{array}$ & $\begin{array}{l}\text { 0- to } 5 \text {-feet diameter. } \\
6 \text { - to } 12-\text { feet diameter. } \\
\text { 13- to } 24 \text {-feet diameter. } \\
25-\text { to } 40 \text {-feet diameter. } \\
\text { Greater than } 40 \text {-feet diameter. } \\
\text { Two storied (overstory two size classes } \\
\quad \text { larger than understory). }\end{array}$ \\
\hline $\begin{array}{l}\text { Crown density of primary } \\
\text { conifers or hardwoods. }\end{array}$ & $\begin{array}{l}S \\
P \\
N \\
G\end{array}$ & $\begin{array}{l}\text { 10- to } 19 \text {-percent crown cover. } \\
20 \text { - to } 39 \text {-percent crown cover. } \\
40 \text { - to } 69 \text {-percent crown cover. } \\
\text { Greater than or equal to } 70 \text {-percent crown } \\
\text { cover. }\end{array}$ \\
\hline Understory vegetation....... & $\begin{array}{l}/ \mathrm{NC} \\
/ \mathrm{NG} \\
/ \mathrm{SA} \\
/ \mathrm{SB} \\
/ \mathrm{SC} \\
/ \mathrm{SM} \\
/ \mathrm{SR} \\
/ \mathrm{SX}\end{array}$ & $\begin{array}{l}\text { Noncommercial conifers. } \\
\text { Herbs and grasses. } \\
\text { Chaparral (manzanita and associated shrubs). } \\
\text { Sagebrush. } \\
\text { Bush (chinquapin). } \\
\text { Montane (buckbrush, chokecherry, whitethorn). } \\
\text { Streamside (wet-meadow or bog shrubs). } \\
\text { Miscellaneous shrubs (bitterbrush, mountain } \\
\text { mahogany). }\end{array}$ \\
\hline
\end{tabular}

Nonwoody- and shrub-vegetation areas

\begin{tabular}{rll}
\hline Dominant vegetative cover.... & GH & Herbaceous cover. \\
& GL & Grasses. \\
& NG & Herbs and grasses. \\
& SA & Chaparral (manzanita and associated shrubs. \\
SB & Sagebrush. \\
SC & Shrub (chinquapin). \\
SM & Montane (buckbrush, chokecherry, whitethorn). \\
SR & Riparian vegetation (wet-meadow or bog shrubs). \\
SX & Miscellaneous shrubs (bitterbrush, mountain \\
& mahogany).
\end{tabular}

\section{Nonvegetated areas}

\begin{tabular}{|c|c|c|}
\hline $\begin{array}{l}\text { Dominant characteristic or } \\
\text { feature. }\end{array}$ & NB & $\begin{array}{l}\text { Barren, rocky. } \\
\text { Urban development (settlements, quarries, } \\
\text { roads) }\end{array}$ \\
\hline
\end{tabular}


Table 3. Classification categories used by U.S. Forest Service on riparian-vegetation maps [Modified from Joseph Oden (U.S. Forest Service, written commun., 1990)]

\begin{tabular}{|c|c|}
\hline $\begin{array}{l}\text { Class- } \\
\text { unit } \\
\text { symbol }\end{array}$ & Class description \\
\hline 1 & $\begin{array}{r}\text { Coniferous riparian............ Fir, hemlock, pine; usually occupies narrow zones } \\
\text { bordering perennial or intermittent streams. }\end{array}$ \\
\hline 2 & $\begin{aligned} \text { Deciduous riparian.............. Aspen, alder, cottonwood, willow; commonly occurs } \\
\text { in linear distributions along streams but also } \\
\text { occupies some broad open areas. }\end{aligned}$ \\
\hline 3 & $\begin{array}{c}\text { Deciduous/coniferous riparian.... Mix of classes } 1 \text { and } 2 \text { (deciduous trees in under- } \\
\text { story, conifers in overstory). }\end{array}$ \\
\hline 4 & $\begin{array}{c}\text { Wet meadow........................ Sedges, rushes, aquatic plants, wet-site grasses; } \\
\text { usually occurs in broad extensive areas but also } \\
\text { occupies some smaller sites along streams or near } \\
\text { lakes. }\end{array}$ \\
\hline 5 & Moist meadow................ Forbs, grasses, some sedges or rushes. \\
\hline $\mathrm{X}$ & $\begin{array}{c}\text { Nonriparian................ Nonriparian plant communities enclosed by areas of } \\
\text { riparian vegetation. }\end{array}$ \\
\hline$W$ & $\begin{array}{c}\text { Water................. Bodies of water surrounded by areas of riparian } \\
\text { vegetation. }\end{array}$ \\
\hline
\end{tabular}

0.4 hectare in size (Joseph Oden, U.S. Forest Service, oral commun., 1991). The riparian-vegetation maps are composed of black thematic linework, labels, and numerous leaders or connecting lines. Mylar copies of these maps were obtained from the USFS.

\section{Land-Capability Maps}

As part of a regional planning framework for the Lake Tahoe basin, the TRPA uses a land-classification system based on land capability, "the level of use an area can tolerate without sustaining permanent damage through erosion and other causes" (Bailey, 1974). Using SCS soil-survey maps, Bailey evaluated the major factors affecting land capability and grouped soil units into seven classes of land capability (table 4). Class 1, consisting of the land least tolerant of use, contains three subclasses, making a total of nine distinct types of land in the basin.

\section{Sources of Digital Data}

Two sets of USGS digital data bases, derived from 1:24,000-scale maps, were available for the Lake Tahoe basin: Digital Line Graph (DLG) and Digital
Elevation Model (DEM). The relevant map quadrangles are listed in table 5.

\section{Digital Line Graph Files}

The DLG data files are grouped into planimetricbase categories: boundaries, hydrography, Public Land Survey System (PLSS), and transportation (U.S. Geological Survey, 1986). These four data categories, which do not necessarily correspond to the separate plates used to print the published USGS topographic maps, are described briefly as follows:

Boundaries. - Political boundaries of States, counties, and cities or other municipalities, and administrative boundaries of areas such as national and State forests.

Hydrography.-Hydrographic features of flowing water, intermittent water, standing water, and wetlands.

PLSS.-Rectangular system of land surveys that is administered by the U.S. Bureau of Land Management for the Western United States.

Transportation.-Major transportation systems in three classes: (1) roads and trails, (2) railroads, and (3) pipelines, transmission lines, and miscellaneous transportation features. 
Table 4. Categories used in land-capability classification

[Modified from table 4 of Bailey (1974, p. 20). do., ditto; --, not applicable or not determined]

\begin{tabular}{|c|c|c|c|c|c|c|c|}
\hline \multicolumn{2}{|c|}{$\begin{array}{c}\text { Land } \\
\text { capability }\end{array}$} & \multirow[b]{2}{*}{$\begin{array}{l}\text { Relative } \\
\text { tolerance } \\
\text { for use }\end{array}$} & \multirow[b]{2}{*}{$\begin{array}{c}\text { Slope } \\
\text { (percent) }\end{array}$} & \multicolumn{2}{|c|}{ Classification basis } & \multirow[b]{2}{*}{$\begin{array}{l}\text { Disturbance } \\
\text { hazard }\end{array}$} & \multirow[b]{2}{*}{ Other } \\
\hline Class & Subclass & & & $\begin{array}{l}\text { Relative } \\
\text { erosion } \\
\text { potential }\end{array}$ & $\begin{array}{c}\text { Relative } \\
\text { runoff potential }\end{array}$ & & \\
\hline \multirow[t]{3}{*}{1} & $1 \mathrm{a}$ & Least & $30+$ & High & $\begin{array}{l}\text { Moderately high } \\
\text { to high. }\end{array}$ & High & -- \\
\hline & $1 b$ & -- & -- & -- & -- & do. & $\begin{array}{c}\text { Poor natural } \\
\text { drainage. }\end{array}$ \\
\hline & $1 c$ & -- & -- & -- & -- & do. & $\begin{array}{c}\text { Fragile flora } \\
\text { and fauna. }\end{array}$ \\
\hline 2 & -- & -- & $30-50$ & High & $\begin{array}{l}\text { Low to moderately } \\
\text { low. }\end{array}$ & do. & -- \\
\hline 3 & -- & -- & $9-30$ & Moderate & $\begin{array}{l}\text { Moderately high } \\
\text { to high. }\end{array}$ & Moderate & -- \\
\hline 4 & -- & -- & $9-30$ & do. & $\begin{array}{l}\text { Low to moderately } \\
\text { low. }\end{array}$ & do. & -- \\
\hline 5 & -- & -- & $0-16$ & Slight & $\begin{array}{l}\text { Moderately high } \\
\text { to high. }\end{array}$ & Low & -- \\
\hline 6 & -- & -- & $0-16$ & do. & $\begin{array}{l}\text { Low to moderately } \\
\text { low. }\end{array}$ & do. & -- \\
\hline 7 & -- & Most & $0-5$ & do. & do. & do. & -- \\
\hline
\end{tabular}

\section{Digital Elevation Model Files}

A 1:24,000-scale DEM data file contains a regular array of elevations and covers one map quadrangle. The stored elevation values are in meters above sea level. The array is based on a 30-meter spacing in the local Universal Transverse Mercator (UTM) coordinate system (U.S. Geological Survey, 1987).

\section{Sources of Hydrographic Data}

Hydrographic data for mapping drainage-basin boundaries, hydrologic-monitoring sites, water bodies, and stream channels came from several sources. The drainage-basin boundaries were identified on topographic maps of the basin. Monitoring-site locations were obtained from records of several government agencies. Coordinates of water bodies and stream channels were derived from USGS DLG files, as described in the section "Digital Line Graph Files."

\section{Drainage-Basin Boundaries}

Jorgensen and others (1978) delineated drainagebasin boundaries on the basis of 1:62,500-scale maps for an earlier study. They delineated drainage basins for major tributaries to Lake Tahoe and above selected surface-water monitoring sites.

For this study, drainage-basin boundaries were delineated on USGS 1:24,000-scale topographic maps. Drainage basins were delineated for major tributaries to Lake Tahoe, above all stream confluences shown on the maps, and above selected surface-water monitoring sites. The 1978 map was not digitized for this study, although the drainage-basin coding system used by Jorgensen was retained.

\section{Hydrologic-Monitoring Sites}

Tabulated information about hydrologic-monitoring sites was obtained from Federal, State, and local agencies working in the Lake Tahoe basin. These agencies include the USGS, USFS, SCS, NDEP, and LWQCB. Data were compiled for surface-water and ground-water monitoring stations and for snow-measurement courses.

The USGS has collected surface-water data in the Lake Tahoe basin since 1895 (Eisenhuth, 1968). Some of the surface-water monitoring sites have more than 90 years of streamflow record; most of the sites 
Table 5. Map quadrangles used as source maps for Digital Line Graph and Digital Elevation Model computer files

[All maps: 1:24,000 scale; polyconic projection. --, no revision]

\begin{tabular}{|c|c|c|}
\hline \multirow{2}{*}{ Map quadrangle } & \multicolumn{2}{|c|}{ Publication dates } \\
\hline & Original & $\begin{array}{l}\text { Revised } \\
\text { edition }\end{array}$ \\
\hline Caples Lake, Calif......... & . 1969 & 1979 \\
\hline Carson Pass, Calif.......... & .. 1976 & 1979 \\
\hline Echo Lake, Calif........... & . 1955 & 1969 \\
\hline Emerald Bay, Calif.......... & . 1955 & 1969 \\
\hline Freel Peak, Calif........... & . 1955 & $\begin{array}{l}1969 \\
1980\end{array}$ \\
\hline 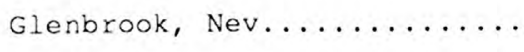 & . 1955 & 1982 \\
\hline Homewood, Calif........... & . 1969 & -- \\
\hline Kings Beach, Calif. and Nev.. & . 1969 & -- \\
\hline Marlette Lake, Nev......... & .. 1955 & 1982 \\
\hline Martis Peak, Calif. and Nev.. & .. 1955 & $\begin{array}{l}1969 \\
1973\end{array}$ \\
\hline Meeks Bay, Calif. and Nev.... & . 1969 & -- \\
\hline Mount Rose, Nev........... & . 1968 & 1982 \\
\hline Pyramid Peak, Calif........ & .. 1969 & -- \\
\hline Rockbound Valley, Calif..... & .. 1969 & -- \\
\hline $\begin{array}{l}\text { South Lake Tahoe, Calif. and } \\
\text { Nev. }\end{array}$ & 1982 & -- \\
\hline Tahoe City, Calif.......... & . 1969 & -- \\
\hline
\end{tabular}

have less than 5 years of record. The USGS has collected ground-water data in the basin since the 1960's and predominantly since 1986 . Water-quality data have been collected at both surface- and ground-water monitoring sites. Many of the USGS sites are also used by the USFS, NDEP, or LWQCB. The USFS (written commun., 1991) collects data on water quality, streamflow, and ground-water and lake-surface levels. The NDEP (written commun., 1991) operates 10 surfacewater monitoring sites in the vicinity of Incline Village, Nev., and collects data on water quality, streamflow, and lake-surface levels. The LWQCB (written commun., 1991) maintains ground-water monitoring sites in the vicinity of South Lake Tahoe, Calif., and collects data on water quality and ground-water levels. Also, the SCS (written commun., 1991) has maintained snow-course monitoring sites in the Lake Tahoe basin since 1913. As of 1991, the SCS snow-telemetry network included eight sites in the basin.

\section{DEVELOPMENT OF SPATIAL DATA BASES}

Digital spatial data bases were created as GIS coverages for 22 thematic layers. The data were derived from thematic maps, digital maps, and hydrographic data. The coverages developed for the TEGIS project are listed in table 6.

\section{Development of Thematic Maps}

Eight coverages were created from thematic maps. The source maps were digitized both automatically by using an electronic scanner and manually on a digitizing table. The coverages are named GEOL_COMP (composite geology), GEOL_COMP_LIN (linear features of composite geology), GEOL_TRPA (geology from TRPA's natural-hazards map), GEOL_TRPA_LIN (linear features of geology from TRPA's natural-hazards map), LAND_CAP (land capability), RIPARIAN_VEG (riparian-vegetation units), SOIL (soil-survey units), and TIMBER_TYPE (timber-type units). The coverages of composite geology were created by appending coverages derived from the best available maps. The resulting composite coverages contain map features derived from source maps at different scales: three at 1:24,000; seven at 1:62,500; and six at 1:125,000.

Source maps were digitized by using the electronic scanner if the available map copy was substantially free of unwanted extraneous features such as cartographic text or topographic contour lines. Wherever possible, automatic digitizing was used in preference to manual digitizing because the product obtained from the electronic scanner was considered to have lower cost of production and comparable or better positional accuracy.

The manually digitized coverages were edited by using software commands available in ARC/INFO. The automatically digitized coverages were edited by using both ARC/INFO commands and software routines developed for this study. 
Examples of coverage line features (scanned and edited) for timber-type and soil units are shown in figure 5, which depicts part of the South Lake Tahoe, Calif. and Nev., map quadrangle. The coverages were processed from the maps represented in figure 3.

\section{Registering Maps}

The $x-y$ coordinates of all digitized features were transformed from digitizer units to map units. The digitizing equipment used in this study records initial coordinates in digitizer inches, which must be converted by linear transformation to the coordinate system of the projection of the source map. This transformation requires at least four control points with $x-y$ values that are known in both coordinate systems digitizer inches and map units. For this study the registration marks at the four corners of each map, corresponding to the 7.5-minute grid of latitude and longitude, were used as control points.

During manual digitizing, maps were registered before digitizing their features. If necessary and when possible, the maps were reregistered until the rootmean-square (RMS) error of the transformation was equal to or less than 0.003 digitizer inches (approximately 0.08 millimeters). Maps that were scanned electronically could not be registered prior to digitizing. Features from these maps were transformed after initial editing.

All digitized features were transformed from digitizer inches directly into UTM coordinates. In theory, to minimize distortion, features should be transformed into the coordinate system of the source map (commonly polyconic) and then projected into UTM coordinates. In practice, for maps covering relatively small areas, the maximum distortion that results from transforming directly to UTM coordinates does not exceed 0.05 millimeters (Snyder, 1987, p. 127). For this study, this maximum potential error was within acceptable limits.

After map data are converted to coverages in a common coordinate system, they may be combined. Coverages from adjacent maps may be appended, or mosaicked, into a larger coverage. For this study, all final coverages are stored in units of meters referenced to the UTM, zone 11 , coordinate system.

\section{Digitizing Spatial Features}

The maps used for the geologic, timber-type, and riparian-vegetation thematic layers required no preparation prior to digitizing. The maps used for the soils thematic layer were available only on folded paper. Prior to digitizing, the maps were heated and smoothed using a household clothing iron. This process removed most of the paper creases and introduced minimal paper distortion.

The TRPA natural-hazards map and three of the soils maps were unsuitable for automatic scanning. These maps were digitized manually by following techniques described by the Environmental Systems Research Institute (1989), the developer of the ARC/INFO software.

The remaining map sheets for the geologic, soils, timber-type, and riparian-vegetation layers were scanned electronically at a resolution of 300 dots per inch. The scanner generated raster-format files, which were converted automatically to a vector format. The vector files contained point-to-point coordinates in digitizer inches. Techniques for operation of the scanner and conversion software are described in a manual by Soller and others (1990).

For each thematic layer, several test areas on a representative map were selected and scanned. Scanner settings were adjusted to minimize the number of undesired spatial features, such as unwanted cartographic features and shading patterns, and to maximize the continuity of linework and positional fidelity of the scanned product to the source map.

Most of the maps were scanned twice, without changing the registration, prior to removal from the scanner. For one of the scans, settings were adjusted to produce the best set of single arcs. For the other scan, settings were adjusted to produce a set of two parallel arcs, corresponding to the outer edge of each line on the source map. The resulting "hollow-line" coverage contains information about the source linework that can aid in adjusting the vectorized coordinates of its single-line counterpart.

\section{Editing Digital Spatial Data}

The coverages derived from thematic maps were edited for continuity and spatial positioning by using ARC/INFO. Scanned coverages also were edited to remove unwanted spatial features that were not pertinent to the thematic layer and scanning artifacts (such 
Table 6. Spatial data bases developed from thematic maps, digital data, and hydrographic data

[DEM, Digital Elevation Model; DLG, Digital Line Graph; Do. or do., ditto; GIS, geographic information system; LWQCB, Lahontan Water Quality Control Board; NDEP, Nevada Division of Environmental Protection; PLSS, Public Land Survey System (township-range grid, including section lines); SCS, U.S. Soil Conservation Service; TRPA, Tahoe Regional Planning Agency; USFS, U.S. Forest Service; USGS, U.S. Geological Survey]

\begin{tabular}{|c|c|c|}
\hline \multicolumn{2}{|c|}{ GIS coverage } & Description of contents of data base \\
\hline Name & Type & Information type \\
\hline 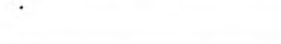 & & Thematic source maps \\
\hline EOL_COMP $\ldots \ldots$. & Polygon... & $\begin{array}{l}\text { Areal geology....... Composited from digital data bases developed } \\
\text { from maps by Thompson and white (1964); } \\
\text { Bonham and Burnett (1976); Loomis (1981); } \\
\text { Armin and John (1983); Armin and others } \\
\text { (1984); and Grose (1985, 1986); and from } \\
\text { TRPA natural-hazards maps (Tahoe Regional } \\
\text { Planning Agency, written commun. 1989). } \\
\text { (See fig. 4 and table } 1 \text { for information on } \\
\text { coverage of individual source maps.) }\end{array}$ \\
\hline GEOL_COMP_LIN ... & Line..... & $\begin{array}{l}\text { Geologic linear } \\
\text { features. }\end{array}$ \\
\hline GEOL_TRPA...... & Polygon... & $\begin{array}{c}\text { Areal geology........ Digitized from TRPA natural-hazards maps (Taho } \\
\text { Regional Planning Agency, written commun., } \\
1989) .\end{array}$ \\
\hline GEOL_TRPA_LIN... & Line..... & do do............ \\
\hline LAND_CAP $\ldots \ldots \cdots$ & Polygon... & $\begin{aligned} \text { Land capability...... Derived from soil-survey GIS by aggregating SC } \\
\text { soil units (Bailey, 1974; Rogers, 1974). } \\
\text { (See table 7.) }\end{aligned}$ \\
\hline RIPARIAN_VEG $\ldots$ & . do...... & $\begin{array}{l}\text { Digitized from U.S. Forest Service (Joseph } \\
\text { Oden, written commun., 1990) riparian-vege- } \\
\text { tation maps. }\end{array}$ \\
\hline SOIL ......... & $\ldots$ do $\ldots .$. & $\begin{array}{l}\text { Soil-survey units.... Digitized from SCS soil-survey maps (Rogers, } \\
\qquad 974) .\end{array}$ \\
\hline TIMBER_TYPE $\ldots$. & $\ldots$ do.... & $\begin{array}{l}\text { Timber-type units.... Digitized from U.S. Forest Service (Joseph } \\
\text { Oden, written commun., 1989) timber-classi- } \\
\text { fication maps. }\end{array}$ \\
\hline
\end{tabular}

\section{Digital sourie data}

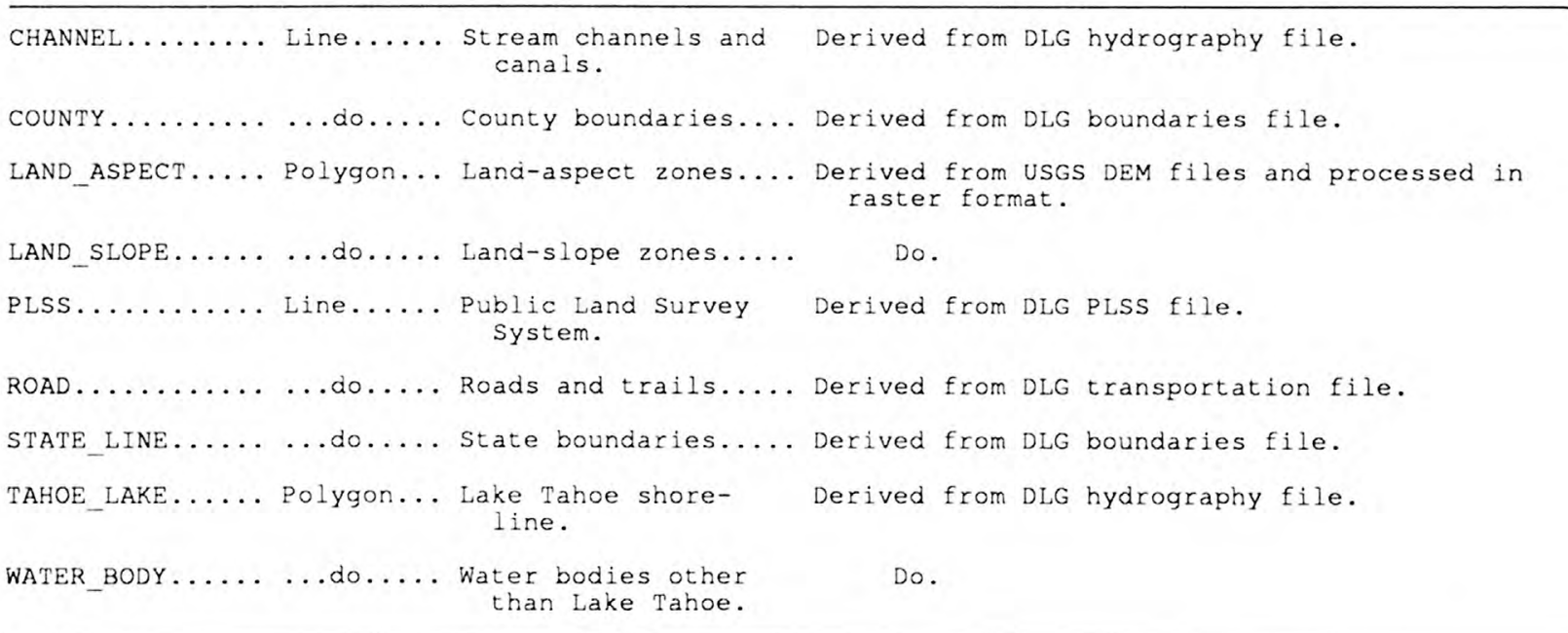


Table 6. Spatial data bases developed from thematic maps, digital data, and hydrographic datacontinued

\begin{tabular}{|c|c|c|c|}
\hline \multicolumn{2}{|c|}{ GIS coverage } & \multicolumn{2}{|c|}{ Description of contents of data base } \\
\hline Name & Type & Information type & Derivation \\
\hline \multicolumn{4}{|c|}{ Hydrographic source data } \\
\hline BOUND_BASIN $\ldots$. & Polygon... & $\begin{array}{l}\text { Lake Tahoe basin } \\
\text { boundary. }\end{array}$ & $\begin{array}{l}\text { Digitized from drainage-basin delineation on } \\
\text { 1:24,000-scale topographic maps. }\end{array}$ \\
\hline BOUND_OUTER.... & $\ldots$ do.... & $\begin{array}{l}\text { Outermost extent of } \\
\text { combined Lake } \\
\text { Tahoe basin and } \\
\text { TRPA administra- } \\
\text { tive boundaries. }\end{array}$ & $\begin{array}{l}\text { Derived from BOUND_BASIN and BOUND_TRPA GIS } \\
\text { coverages. }\end{array}$ \\
\hline BOUND_TRPA..... & .. do.... & $\begin{array}{l}\text { TRPA administrative } \\
\text { boundary. }\end{array}$ & $\begin{array}{l}\text { Digitized from drainage-basin delineation on } \\
1: 24,000-\text { scale topographic maps and adjusted } \\
\text { by using PLSS and CoUNTy spatial data bases. }\end{array}$ \\
\hline HYD_BASIN...... & ...do.... & $\begin{array}{l}\text { Hydrologic drainage- } \\
\text { basin boundaries. }\end{array}$ & $\begin{array}{l}\text { Digitized from drainage-basin delineation on } \\
\text { 1:24,000-scale topographic maps. }\end{array}$ \\
\hline MONITOR_SITE.... & Point.... & $\begin{array}{l}\text { Hydrologic-monitor- } \\
\text { ing sites. }\end{array}$ & $\begin{array}{l}\text { Compiled from records from LWQCB, NDEP, SCS, } \\
\text { USFS, and USGS. }\end{array}$ \\
\hline
\end{tabular}

as false linework from shaded areas on the map or feature labels). Arcs were selected manually by using a graphic-interface device, such as an electronic mouse or cursor, or automatically by using computer routines written in the Arc Macro Language (AML). Macro routines identified coverage arcs by using topological characteristics such as arc length, number of intersecting arcs, and adjacency to closed or open polygons. The macro routines were designed to decrease processing time and increase efficiency of cleaning large coverages that were created by using electronic scanners (Cartier, 1992).

Verification plots of each coverage were created at original scale on stable-base mylar film by using 0.3 millimeter ink pens. The verification plots were overlaid on the source map and visually examined for accuracy according to the criterion described by Campbell and Mortenson (1989). Corrections were made to the coverage where an ink-free space could be detected between the map and verification plot and the error exceeded 0.3 millimeters.

Coverages created by electronic scanning also were verified by using a computer monitor. Each coverage was compared with its corresponding hollow-line coverage. Linework was corrected wherever it lay outside the hollow lines or formed webbing patterns. These webs are a common artifact of scanning and vectorizing, especially near multiple-line intersections or where lines join at an angle of less than 10 degrees.
Further processing of the thematic coverages included replacing the scanned water-body boundaries with those derived from the DLG files and adding a boundary arc for the Lake Tahoe basin. These standardized arcs were used in the coverages so that the coordinates for water bodies and the Lake Tahoe basin would be identical on each thematic layer. First, the scanned linework for water bodies was removed by selecting and deleting the unwanted arcs interactively. Arcs from the DLG files then were added to the remaining arcs in the coverage. Where the standardized arcs did not join with the scanned linework, connecting arcs were added. Where the linework from the thematic maps extended beyond the standardized basin boundary, the extensions were deleted. Where the standardized basin boundary was positioned beyond the linework of the thematic map, both the standardized and scanned arcs were preserved and the intervening polygon was assigned a null value.

After editing, including replacing the arcs for water bodies and the basin boundary, the 16 quadrangle-based coverages of each layer were appended to each other to form single thematic coverages for the entire basin. Along many of the coverage boundaries, the linework from adjacent maps was found to be misaligned. This discrepancy is a common consequence of merging adjacent maps. The process of resolving the discrepancies is referred to as edgematching (Nebert, 1989). Coverage edgematching was performed inter- 

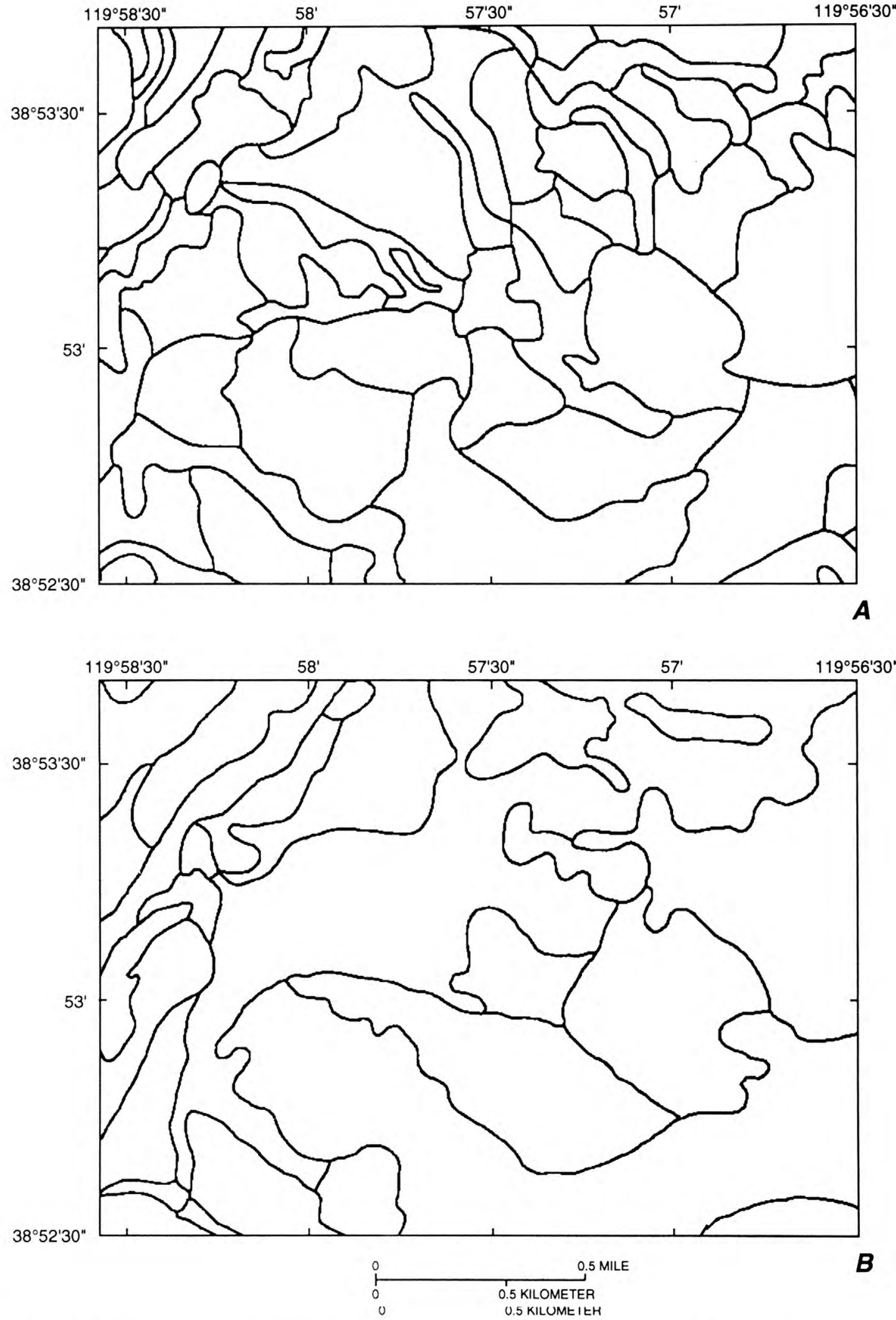

Figure 5. Example plots of digital maps developed from thematic source maps for part of South Lake Tahoe map quadrangle. Plots contain spatial features without feature labels and represent same geographic area and thematic layers as portrayed in figure 3. A, Data base from U.S. Forest Service timbertype map. B, Data base from U.S. Soil Conservation Service soil-survey map. 
actively using the ArcEdit subsystem of ARC/INFO. The linework along the edges of adjacent maps was connected topologically by using the following rules:

(1) If the misalignment between connecting arcs was small (equivalent to less than 10 meters in UTM coordinates), the arcs were automatically joined, or snapped, to each other.

(2) If the misalignment was moderate (10 to 15 meters), the source maps were inspected to resolve the discrepancy. If the discrepancy could be resolved, the arcs were moved accordingly so that they matched.

(3) If the misalignment was large (greater than 15 meters) or if a discrepancy could not be resolved, the arcs were not moved and a connecting line was added between the two arc ends.

\section{Assigning Attributes to Map Features}

Attributes are the numeric and textual information associated with spatial features in a coverage. For example, map-unit codes for timber types (table 19; figure $3 A$ ) are attributes. Coverage features were assigned attribute values according to map units that were labeled on the source maps. The attribute data were verified by comparing scaled plots of the coverages to the source maps. Any necessary corrections were made to the coverage, and the verification procedure was repeated until no further errors were detected.

Attribute errors on the original maps included unknown or missing attribute labels for polygons, more than one attribute label per polygon, and adjacent polygons with the same attribute value. Attribute errors were identified for the digitized layers of geology, soil, timber type, and riparian vegetation. The number of errors ranged from 2 to 148 per layer for the entire study area. Polygon features having these errors were brought to the attention of the agency from which the original maps were obtained. A specialist within each organization determined the correct attribute values for mislabeled features, and coverages were updated accordingly.

\section{Deriving Land-Capability Classification}

The land-capability layer was derived from the digitized SCS soil-survey maps according to criteria specified by Bailey (1974). Each of the 49 types of soils was assigned to one of 9 types of land capability.
Polygons of soil units that had the same land capability were merged to create the coverage called LAND_CAP. The system of land-capability classification and corresponding SCS soil-unit symbols are shown in table 7 .

\section{Development of Digital Data}

Nine coverages of planimetric data were derived from DLG or DEM files. The seven coverages derived from DLG files are CHANNEL (stream channels and canals), COUNTY (county boundaries), PLSS (Public Land Survey System), ROAD (roads and trails), STATE_LINE (California-Nevada State line), TAHOE_LAKE (Lake Tahoe boundary), and WATERBODY (boundaries of water bodies other than Lake Tahoe). The two coverages derived from DEM files are LAND_SLOPE (slope classes) and LAND_ASPECT (aspect classes). Examples of some of the coverages derived from DLG and DEM files for part of the South Lake Tahoe, Calif. and Nev., map quadrangle are shown in figure 6.

\begin{tabular}{|c|c|c|}
\hline $\begin{array}{l}\text { [Modif } \\
\text { is for } \\
\text { vice s }\end{array}$ & $\begin{array}{l}\text { ed from } \\
\text { explanati } \\
\text { oil-unit c }\end{array}$ & $\begin{array}{l}\text { ailey }(1974, \text { p; } 29-32) \text {. See table } \\
\text { on of U.S. Soil Conservation Ser- } \\
\text { odes. --, not applicablel }\end{array}$ \\
\hline Land $c$ & apability & $\begin{array}{l}\text { Corresponding U.S. Soil } \\
\text { Conservation Service }\end{array}$ \\
\hline Class & Subclass & soil-unit codes \\
\hline 1 & $1 \mathrm{a}$ & $\begin{array}{l}\text { CaF, GsE, MsE, MsG, MtE, MtG, } \\
\text { RcE, RcG, RtE, RtG, ShE, SkE, } \\
\text { TeG, TmE, TmE, TrE, TrF, UmF, } \\
\text { WaF, WcE. }\end{array}$ \\
\hline & $1 b$ & Be, Co, Ev, Ed, Gr, Lo, Mh. \\
\hline & $1 c$ & $M x E, M x F, P x, R a, R x, S m$. \\
\hline 2 & -- & CaE, JwE. \\
\hline 3 & -- & $\begin{array}{l}\text { EuE, JaD, JbD, JeD, MkD, MsD, TeE, } \\
\text { UmE, WaE, WcE. }\end{array}$ \\
\hline 4 & -- & $C a D, E b E, E c E, G e D$, IsD, IsE, JwE. \\
\hline 5 & -- & $\begin{array}{l}\text { Fud, IgB, JaC, JeB, JgC, JhC, MkB, } \\
\text { MmB, TCB, TCC, TdD, TKC, UmD. }\end{array}$ \\
\hline 6 & -- & EbC, GeC, IsC, JtD, JWD, TaD, TbD. \\
\hline 7 & -- & EfB. \\
\hline
\end{tabular}



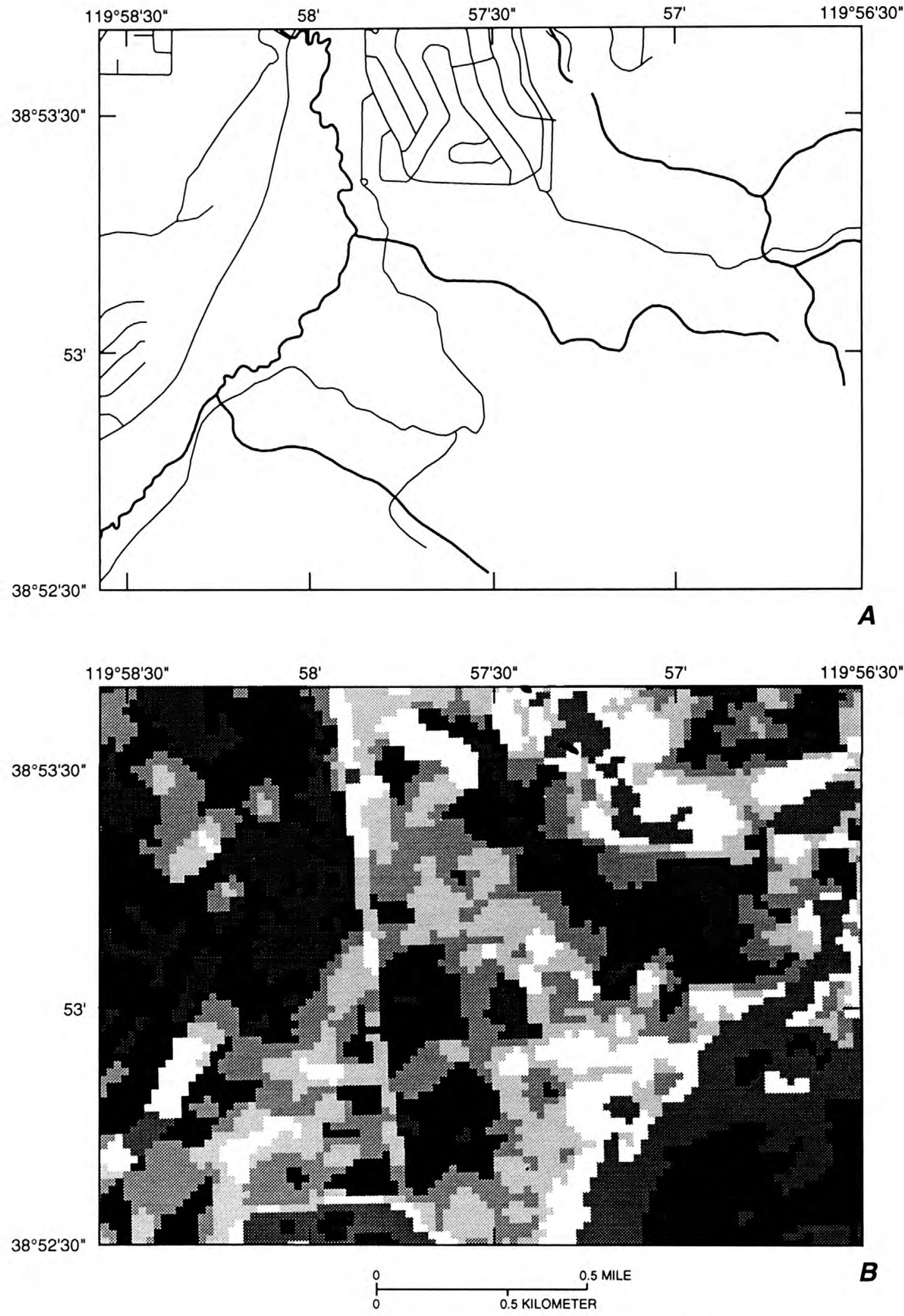

Figure 6. Example plots of spatial data bases derived from Digital Line Graph and Digital Elevation Model files. Plots cover part of South Lake Tahoe map quadrangle and represent same geographic area as portrayed in figures 3 and 5. A, Road and channel data bases from transportation and hydrography Digital Line Graph files. Thicker lines represent streams, and thinner lines, roads. B, Slope data base from Digital Elevation Model files. Shade patterns indicate slope categories. 


\section{Planimetric-Base Features}

The DLG files were converted into coverages by using ARC/INFO software. The coverages COUNTY and STATE_LINE were derived from the DLG boundaries files. The coverages CHANNEL, TAHOE_LAKE, and WATERBODY were derived from the DLG hydrography file. The coverage PLSS was derived from the DLG Public Land Survey System files.

For each layer, 16 individual coverages, 1 for each map quadrangle, were appended into a single basinwide coverage. When discrepancies were found between coverage arcs on adjacent coverages, the arcs were connected using the predefined set of rules described in the section titled "Editing Digital Spatial Data."

Two additional modifications were made to the stream-channel coverage (CHANNEL). First, the coding for the beginning and ending of arcs was adjusted to indicate the true down-gradient direction. Second, arcs were added to connect stream channels across water-body polygons. These connecting arcs create linear continuity, which is useful for hydrologic investigations such as streamflow routing.

\section{Slope and Aspect}

Sixteen DEM files were used to generate coverages of aspect and slope for the Lake Tahoe basin, 11 from UTM zone 10 and 5 from UTM zone 11. The DEM is a digital representation of the irregular surface of the Earth. The inclination of a surface at a given point has two components, slope (steepness) and aspect (compass direction).

The DEM data were processed by using raster techniques available through NASA's ELAS system

(Beverley and Penton, 1989). ELAS is a modular GIS and image-processing system used primarily for processing remotely sensed data, but it also can be used for processing regularly spaced data, such as DEM files.

Initial mosaicking of a few DEM files was accomplished in part by using ARC/INFO software. The size of each DEM data file ranged from 473 to 475 rows and 374 to 376 columns. Only DEM files in the same UTM zone were merged and processed together. The mosaicking process was limited to a maximum of four DEM files, in blocks of two wide by two high.
Each mosaic then was converted to ARC/INFO's single-variable file (SVF) format structure. This file type then was converted to ELAS file structure.

Once in ELAS format, the files were merged into larger mosaic files. The two UTM zones, 10 and 11, are separated by the 120-degree meridian of longitude. The 11 files for areas west of long $120^{\circ} \mathrm{W}$. (UTM zone 10) were mosaicked and processed together. Three of the five files for areas east of long $120^{\circ} \mathrm{W}$. (UTM zone 11) were mosaicked and processed together. The Freel Peak map quadrangle is east of long $120^{\circ} \mathrm{W}$., but the corresponding DEM file was available only in UTM zone 10 coordinates. Because of this anomaly, the files for the Freel Peak area and the Carson Pass area (south of Freel Peak) could not be mosaicked with files for neighboring areas and were processed separately.

A number of methods can be used to calculate slope and aspect from a regular grid of elevation values (Skidmore, 1989). The ELAS software uses the maximum-gradient method. The method uses a three-bythree window around each cell, or elevation value, in the grid, comparing the center cell with its eight neighbors. Aspect is defined as the direction of maximum steepness, either up or down, from the center cell to one of the eight nearest cells. In other words, aspect is the direction of the maximum gradient. Slope is calculated on the basis of cell size and the difference in elevation values between the center cell and its neighbor in that steepest direction.

Classes for aspect were limited to level and the eight points of the compass (north, northeast, east, southeast, south, southwest, west, and northwest). The term "level aspect" applies when all nine cells of the window have the same elevation value.

Classes for slope were set as follows: 0 to 2 percent, $>2$ to 5 percent, $>5$ to 10 percent, $>10$ to 15 percent, $>15$ to 20 percent, $>20$ to 30 percent, $>30$ to 50 percent, $>50$ to 100 percent, and $>100$ percent. These ranges were selected in order to satisfy requirements of land-use permitting, modeling, and resources management for the Lake Tahoe basin (Deborah Reed, Washoe County Department of Comprehensive Planning, oral commun., 1992).

Nominal filtering was performed on the raster files of slope and aspect. This filtering technique selectively replaces a cell value with a neighboring cell's value if there are not a minimum number of adjacent cells having the same value. The nominal number of cells, set to three, defines the minimum mapping unit to 
be 0.27 hectare. This process significantly reduced the number of polygons in the final coverage while changing relatively few cells.

Raster techniques that use a window around a central cell do not compute values along the edgesthe top and bottom rows and the left and right columns of the array. These cells simply do not have enough neighbors. Because part of the window does not contain valid data, the resulting value for the central cell is null or undefined. If two such raster files are joined along a common edge, the result is a gap of two cells that contain null data.

The raster files of slope and aspect were transferred to ARC/INFO, in SVF format, for further processing. These files were converted into ARC/INFO coverages. Coverages in UTM zone 10 coordinates were projected into UTM zone 11 coordinates. Once all coverages were in the same map projection, they were appended together and edgematched. After appending, gaps of null data existed along edges where coverages were joined. These gaps were filled in with arcs that enclosed areas of the same class on each side of the gap.

\section{Development of Hydrographic Data}

\author{
Four coverages (BOUND_BASIN,
} BOUND_OUTER, BOUND_TRPA, and

HYD_BASIN) were derived from overlays drawn on topographic maps. One coverage (MONITOR_SITE) was derived from records of hydrologic-monitoring sites.

\section{Development of Drainage-Basin Boundaries}

Drainage divides, which define the boundaries of drainage basins and subbasins, were delineated on mylar overlays of 1:24,000-scale topographic maps. The divides were identified for all subbasins above mapped stream confluences, above stream inflows to water bodies, and above selected hydrologic-monitoring sites. The delineations were based on interpretation of the shape of the mapped topographic contour lines and the location of hydrographic features. The drafted lines were verified by two hydrologists. The contour interval on most of the maps was 40 feet (12 meters).
In areas of relatively low gradient, such as the South Lake Tahoe area, the contour interval was 20 feet (6.1 meters).

The drainage-basin boundaries were digitized manually, labeled, and verified by the techniques used for thematic maps as described in the section "Development of Thematic Maps." The HYD_BASIN coverage contains all the drainage-basin boundaries that have been delineated for the Lake Tahoe basin.

Three coverages were developed for the boundary of the Lake Tahoe basin. The BOUND_BASIN coverage contains the drainage-basin boundary for the Lake Tahoe basin above the outflow of Lake Tahoe. To match the TRPA administrative boundary, the BOUND_TRPA coverage was modified from the BOUND_BASIN coverage by replacing part of the drainage-basin boundary with data from the PLSS and COUNTY coverages. These modifications altered the basin boundary to comply with U.S. Public Law 96-551, by which Congress legislated the TRPA's jurisdiction. The BOUND_OUTER coverage contains data for the outer boundary of the Lake Tahoe basin and the administrative boundary of TRPA. The coverage was derived by merging the BOUND_BASIN and BOUND_TRPA coverages and then eliminating internal lines where discrepancies exist.

\section{Development of Hydrologic-Monitoring Sites}

Federal, State, and local agencies were contacted regarding hydrologic data collection in the Lake Tahoe basin. Agencies having active hydrologic programs evaluated each of their monitoring sites for data quality and significance. The agencies considered the completeness and duration of record as well as the hydrologic significance of each site, and determined which monitoring sites were to be included in the GIS data base. The USGS used the following criteria: (1) The site has at least 3 years of record, (2) the site has a current or historically important period of record, and (3) the site has a record of continuous measurements for at least part of the period of record. The agencies also evaluated each of the surface-water monitoring sites for inclusion in a list of sites for delineation of drainage divides.

For this study, the five agencies tabulated the following information for each site: site identification number; descriptive title; site elevation; period of record, in calendar years; site type, such as surface 
water, ground water, or lake; and sampling methods. Site locations were provided either digitally (as latitude/longitude coordinates) or marked on 1:24,000scale topographic maps.

The site-description lists were entered into a relational data base within ARC/INFO and then were used to generate a GIS coverage of point locations. Sites that were marked on topographic maps were digitized manually. The point locations for surface-water sites were compared to the hydrographic-channel coverage and moved to the nearest line segment for the sampled stream channel. The tabular listing of the monitoringsite locations was updated to reflect these adjustments. These records were verified twice by the data-collection agencies.

\section{DOCUMENTATION OF SPATIAL DATA BASES}

Summary information for the thematic layers (geology, hydrologic basins, aspect, slope, land capability, monitoring sites, riparian vegetation, soil, and timber type) developed in the TEGIS project is given in tables 8 through 19. This information includes coverage name, source agency, source-map scale, and a statistical description of the feature attributes. For polygon coverages, the statistical description for each map unit bearing a unique symbol includes the number of noncontiguous occurrences, the basinwide total area and mean area, and the areas of the largest and smallest noncontiguous occurrences. For line coverages, the feature labels correspond to cartographic labels for linear features on the source maps and the statistical summary contains information on the lengths of each feature.

Because map symbols for geology are not consistent among the various source maps, the descriptions of geologic map units include an abbreviated name for the map quadrangle from which they were derived. For further information on the source maps used to compile the digital geologic layer, see table 1 and figure 4 .

The accuracy, resolution, and other characteristics of the final coverages depend on both the characteristics of the source data and the processes used for digitizing the data. Information on the data sources and resulting spatial data bases is summarized in table 20 .

\section{SUMMARY}

Twenty-two spatial data bases were developed for the Lake Tahoe basin as part of the Tahoe Environmental Geographic Information System (TEGIS) project. The data bases were created by using the ARC/INFO vector-based and the ELAS raster-based geographic information systems. The spatial data bases are stored as ARC/INFO coverages, in units of the UTM (zone 11) coordinate system.

The TEGIS spatial data bases were generated from three main sources of geographic information: thematic maps, hydrographic data records, and digital data files. Source data were incorporated by manual digitizing, electronic scanning, or data conversion. Extensive quality-control practices were followed in converting the source information into digital form.

The TEGIS coverages consist of spatial coordinates and attribute data for the following layers:

Basin boundaries-physical boundary of the basin, TRPA administrative boundary, and the composite outermost of these two boundaries;

Geology - areal geology and linear geologic features from the TRPA natural-hazards map and from the composite of the largest scale geologic mapping;

Other thematic data-soil units, timber type, riparian vegetation, and land capability;

Hydrographic data-drainage-basin boundaries and hydrologic-monitoring sites;

DLG digital data-State and county boundaries, roads and trails, Public Land Survey System, stream channels and canals, and boundaries of Lake Tahoe and other water bodies; and

DEM digital data - slope and aspect.

Documentation for and summary information about the spatial data bases include detailed descriptions of all the coverages and brief statistical descriptions of the natural-resources coverages. 


\section{REFERENCES CITED}

Armin, R.A., and John, D.A., 1983, Geologic map of the Freel Peak 15-minute quadrangle, California and Nevada: U.S. Geological Survey Miscellaneous Investigations Series Map I-1424, scale 1:62,500.

Armin, R.A., John, D.A., and Moore, W.J., 1984, Geologic map of the Markleeville 15-minute quadrangle, Alpine County, California, with Quaternary geology, by J.C. Dohrenwend: U.S. Geological Survey Miscellaneous Investigations Series Map I-1474, scale 1:62,500.

Bailey, R.G., 1974, Land-capability classification of the Lake Tahoe basin, California-Nevada-A guide for planning: U.S. Forest Service and Tahoe Regional Planning Agency, 32 p. [available from National Technical Information Service, Springfield, VA 22161 as NTIS Report PB82-163429].

Beverley, A.M., and Penton, P.G., eds., 1989, ELAS, Science and Technology Laboratory Applications SoftwareVol. II, User Reference: National Aeronautics and Space Administration, John C. Stennis Space Center, Science and Technology Laboratory Report 183.

Bonham, H.F., Jr., and Burnett, J.L., 1976, Geologic map of the South Lake Tahoe quadrangle, California-Nevada: Nevada Bureau of Mines and Geology Urban Map Series, South Lake Tahoe Folio Map 2Ag, scale $1: 24,000$.

Burnett, J.L., 1971, Geology of the Lake Tahoe basin: California Geology, v. 24, no. 7, p. 119-127.

Campbell, W.G., and Mortenson, D.C., 1989, Ensuring the quality of geographic information system data-A practical application of quality control: Photogrammetric Engineering and Remote Sensing, v. 55, no. 11, p. 1613-1618.

Cartier, K.D., 1992, Macros for editing geographic information system spatial data bases [abs.], in Balthrop, B.H. and Baker, E.G., compilers, U.S. Geological Survey National Computer Technology Meeting-Program and Abstracts, Norfolk, Virginia, May 17-22, 1992:

U.S. Geological Survey Open-File Report 92-64, p. 4.

Eisenhuth, H.P., 1968, Index of surface-water records to September 30, 1967-Pt. 10, The Great Basin: U.S. Geological Survey Circular 580, 37 p.

Environmental Systems Research Institute, 1989, ARC/INFO-Users guide: Environmental Systems Research Institute, Redlands, Calif., 7 volumes.

Grose, T.L.T., 1985, Geologic map of the Glenbrook quadrangle, Nevada: Nevada Bureau of Mines and Geology Urban Map Series, Glenbrook Folio Map 2Bg, scale $1: 24,000$.

----1986, Geologic map of the Marlette Lake quadrangle, Nevada: Nevada Bureau of Mines and Geology Urban Map Series, Marlette Folio Map 2Cg, scale 1:24,000.
Jorgensen, L.N., Seacer, A.L, and Kaus, S.J., 1978, Hydrologic basins contributing to outflow from Lake Tahoe, California-Nevada: U.S. Geological Survey Hydrologic Investigations Atlas HA-587, scale 1:62,500.

Loomis, A.A., 1981, Geology of the Fallen Leaf Lake quadrangle, El Dorado County, California: California Division of Mines and Geology, scale 1:62,500.

Nebert, D.D., 1989, Review of edgematching procedures for digital cartographic data used in geographic information systems: U.S. Geological Survey Open-File Report 89-579, 12 p.

Rogers, J.H., 1974, Soil survey-Tahoe basin area, California and Nevada: U.S. Soil Conservation Service, 184 p.

Skidmore, A.K., 1989, A comparison of techniques for calculating gradient and aspect from a gridded digital elevation model: International Journal of Geographical Information Systems, v. 3, no. 4, p. 323-334.

Snyder, J.P., 1987, Map projections-A working manual: U.S. Geological Survey Professional Paper 1395, $383 \mathrm{p}$.

Soller, D.R., Stettner W.R., Lanfear, K.J., and Aitken, D.A., 1990, A user's manual for a method of map scanning and digital editing for thematic map production and data-base construction: U.S. Geological Survey Circular 1054, 38 p.

Thompson, G.A., and White, D.E., 1964, Regional geology of the Steamboat Springs area, Washoe County, Nev.: U.S. Geological Survey Professional Paper 458-A, $52 \mathrm{p}$.

U.S. Geological Survey, 1986, National mapping program technical instructions-Data users guide 1, Digital Line Graphs from 1:24,000-scale maps: U.S. Geological Survey, $109 \mathrm{p}$.

---1987, National mapping program technical instructions-Data users guide 5, Digital Elevation Models: U.S. Geological Survey, 38 p. 
TABLES 8-20 
Table 8. Summary documentation for spatial data base GEOL_COMP In Tahoe Environmental Geographic Information system

Description of coverage: Composite polygon coverage of geology derived from digital data bases

Storage format: ARC/INFO

Data source: Digitized from eight geologic and related thematic maps (table 1)

Source scales: From $1: 24,000$ to $1: 125,000$

[Geologic or other map unit: Geologic symbols, unit descriptions or formation names, and age information are as used by authors of cited references and do not necessarliy meet U.S. Geological Survey standards. Geologic map units are listed in alphanumeric order (not chronologicaliy) by map-unit symbol within geologic age groups, which are in order from youngest to oldest. Description: Applies to separate precompilation units if more than one description for given map-unit symbol. Geologic units having no age information and other, nongeologic, units are listed as other map units at end of table. Map-quadrangle names are abbreviated as follows: CLK, Caples Lake, Callf.; CPS, Carson Pass, Calif.; EBY, Emerald Bay, Calif.; ELK, Echo Lake, Callf.; FPK, Freel Peak, Calif.; GBK, Glenbrook, Nev.; HWD, Homewood, Callf.; KBH, Kings Beach, Calif. and Nev.; MBY, Meeks Bay, Calif. and Nev.; MLK, Marlette Lake, Nev.; MPK, Martis Peak, Calif. and Nev.; MRS, Mount Rose, Nev.; Ppk, Pyramid Peak, Calif.; RBV, Rockbound Valley, Calif.; SLT, South Lake Tahoe, Calif. and Nev.; TCY, Tahoe City, Calif. Do. or do., ditto; --, not applicablel

\begin{tabular}{|c|c|c|c|c|c|c|c|}
\hline \multirow{3}{*}{ symbol } & \multirow{3}{*}{ Geologic or other map unit. } & \multicolumn{5}{|c|}{ Occurrences } & \multirow{3}{*}{$\begin{array}{l}\text { Relevant } \\
\text { digitized } \\
1: 24,000-\text { scale } \\
\text { topographic-map } \\
\quad \text { quadrangles }\end{array}$} \\
\hline & & \multirow{2}{*}{$\begin{array}{l}\text { Total } \\
\text { number } \\
\text { basinwide }\end{array}$} & \multicolumn{4}{|c|}{$\begin{array}{l}\text { Area } \\
\text { (square meters) }\end{array}$} & \\
\hline & & & $\begin{array}{l}\text { Basinwide } \\
\text { total }\end{array}$ & Mean & Minimum & Maximum & \\
\hline \multicolumn{8}{|c|}{ Quaternary units } \\
\hline Qa & Sand and gravel alluvium ${ }^{1}{ }^{2} \ldots \ldots \ldots \ldots \ldots \ldots \ldots \ldots$ & 20 & $1,645,802$ & 82,290 & 11,116 & 747,781 & GBK, MLK. \\
\hline Qac & Carbonaceous alluvium ${ }^{1} \ldots \ldots \ldots \ldots \ldots \ldots \ldots \ldots \ldots \ldots$ & 4 & 223,796 & 55,949 & 31,277 & 111,027 & GBK. \\
\hline Qal & 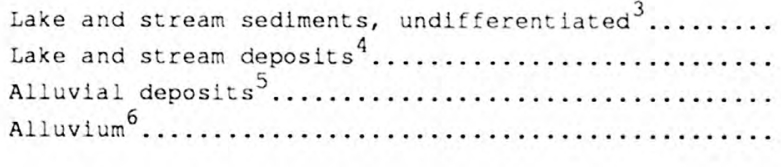 & 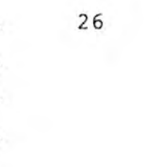 & $32,821,947$ & $1,262,383$ & 2,509 & $26,484,126$ & $\begin{array}{l}\text { EBY, ELK, PPK, RBV. } \\
\text { MRS. } \\
\text { SLT. } \\
\text { CLK, HWD, KBH, MBY, MPK, TCY. }\end{array}$ \\
\hline$Q b$ & 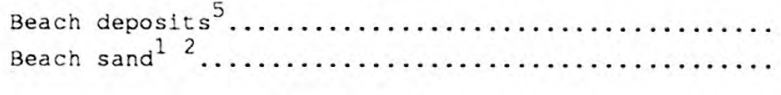 & 14 & $1,007,589$ & 71,971 & 87 & 389,228 & $\begin{array}{l}\text { SLT. } \\
\text { GBK, MLK. }\end{array}$ \\
\hline Qb3 & Beach deposits of tioga age ${ }^{5} \ldots \ldots \ldots \ldots \ldots \ldots \ldots \ldots$ & 1 & 439,236 & -- & -- & -- & SLT. \\
\hline Qbo & 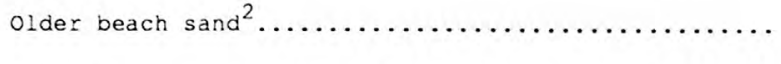 & 1 & 111,475 & -- & -- & -- & MLK. \\
\hline Qc & Sand and boulder colluvium ${ }^{1}{ }^{2} \ldots \ldots \ldots \ldots \ldots \ldots \ldots$ & 25 & $4,586,091$ & 183,444 & 11,931 & $1,085,285$ & GBK, MLK. \\
\hline Qf 3 & 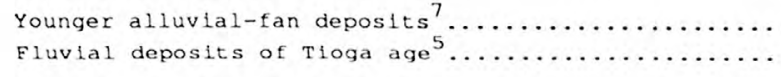 & 9 & $1,601,599$ & 177,955 & 9,268 & 514,232 & $\begin{array}{l}\text { FPK. } \\
\text { SLT. }\end{array}$ \\
\hline
\end{tabular}


Fluvial deposits of pre-Tahoe age

Qf 11

Qf 12

Qfp

Qfy

Qg

Qg5

Q1

Q10

Q10+Qg

Q1

Qm

Qm

Qm3

...do. . .

Flood-plain deposits ${ }^{7}$

Younger alluvial-fan deposits ${ }^{8}$.

Glacial outwash, undifferentiated. Glacial outwash 6

Glacial outwash of pre-Tahoe age ${ }^{5}$

Lake and stream deposits ${ }^{4}$

Lacustrine deposits ${ }^{5}$.

Older lake beds ${ }^{6}$

Older lake sediment 6

Older lake/glacial outwash 6

Landsllde and rockfall deposits ${ }^{5}$

Glacial moratne and

Moraine deposits, undivided ${ }^{7} .$.

Glacial moraines 6

Younger moraine deposits?

Tahoe $\mathrm{TH}_{11}^{4}$.

Tioga $T 111^{4}$.
Flood-plain and lacustrine deposits ${ }^{5}$.

Landslide, rockfalls, and mudflows ${ }^{6} \ldots \ldots \ldots \ldots \ldots . . . . .$.

Glacial deposits, undifferentiated ${ }^{4}$

Glacial till, undifferentiated ${ }^{5} . .$.

Older moraine deposits ${ }^{7} \ldots \ldots \ldots \ldots \ldots \ldots \ldots \ldots \ldots \ldots$

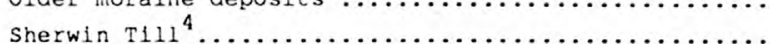

Tloga till $\ldots . .$.

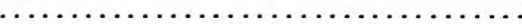

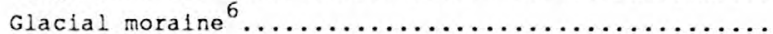

$\begin{array}{lrrrr}1,986,223 & 397,245 & 6,967 & 1,303,224 & \text { SLT. } \\ 4,441,735 & 888,347 & 275 & 3,036,417 & \text { Do. } \\ 3,379,459 & 675,892 & 13,614 & 1,995,255 & \text { Do. }\end{array}$

577,766

97,557

$--$

$--$

$--$

FPK.

$--$

$-\quad$ CPS

$16,126,931 \quad 2,303,847$

4,535

$8,234,586$

SLT.

CLK, HWD, KBH, MBY, MPK, TCY.

\section{$1,860,554 \quad 465,139$}

96,746

891,863

SLT.

$13,763,610 \quad 573,484$

4,385

$6,052,741$

MRS .

SLT.

CLK, HWD, KBH, MBY, MPK, TCY.

$1,319,980$

188,569

39,171

740,015

CLK, HWD, KBH, MBY, MPK, TCY.

$7,926,886 \quad 2,642,295$

348,821

$4,091,445$

CLK, HWD, KBH, MBY, MPK, TCY.

$1,353,053$

169,132

6,641

735,602

SLT

CLK, HWD, KBH, MBY, MPK, TCY.

$47,350,181 \quad 2,959,386$

$9,589 \quad 38,087,520$

EBY, ELK, PPK, RBV.

FPK.

SLT.

CPS.

CLK, HWD, KBH, MBY, MPK, TCY.

2

$2,344,289 \quad 1,172,145$

$494,134 \quad 1,850,156$

FPK.

MRS.

12

$14,670,684 \quad 1,222,557$

$84,627 \quad 5,371,88$

FPK

MRS .

$47,652,504 \quad 4,765,250$

$1,685 \quad 35,315,115$ 
Table 8. Summary documentation for spatial data base GEOL_COMP in Tahoe Environmental Geographic Information System-Continued

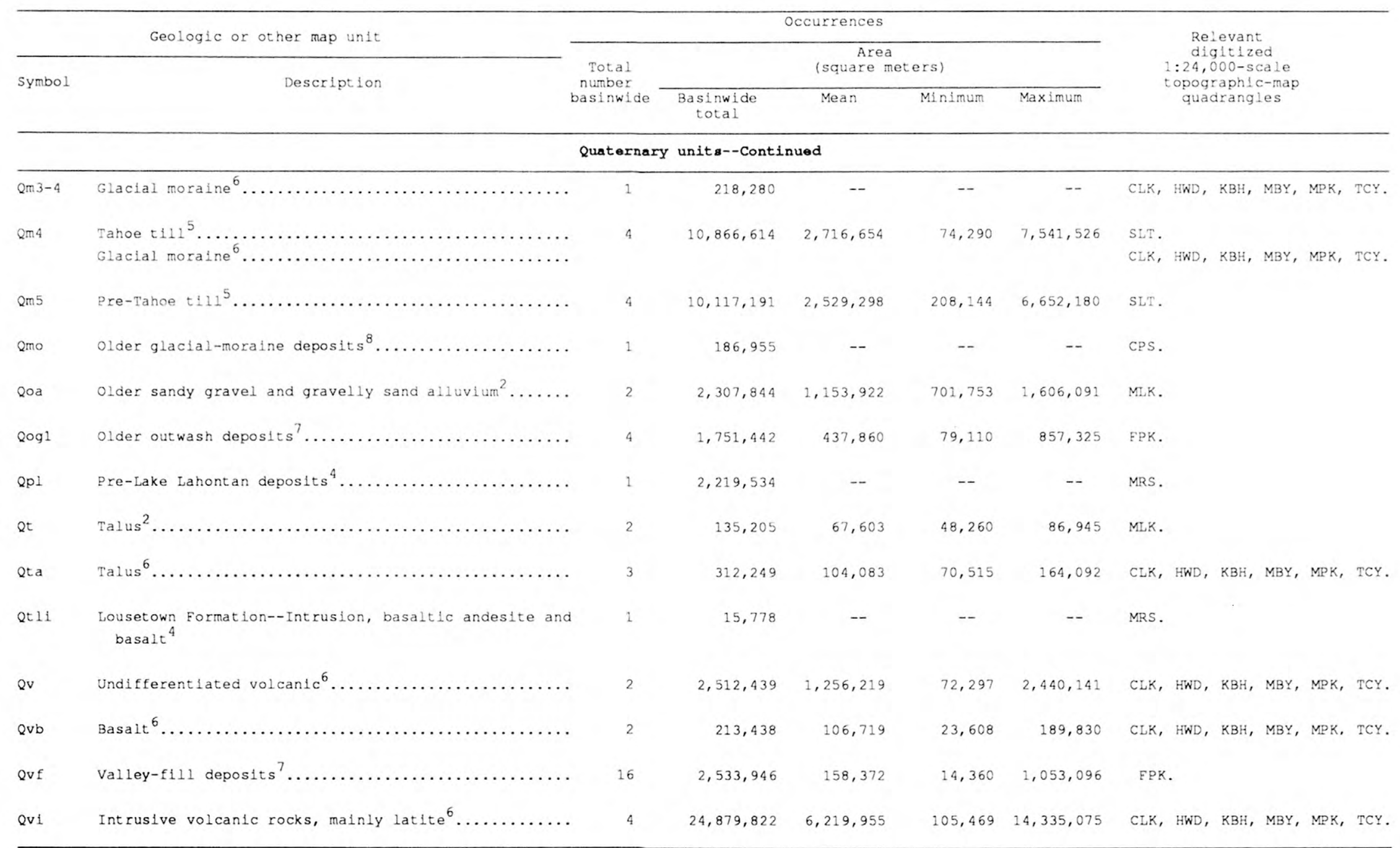

Quaternary and (or) Tertiary unit.

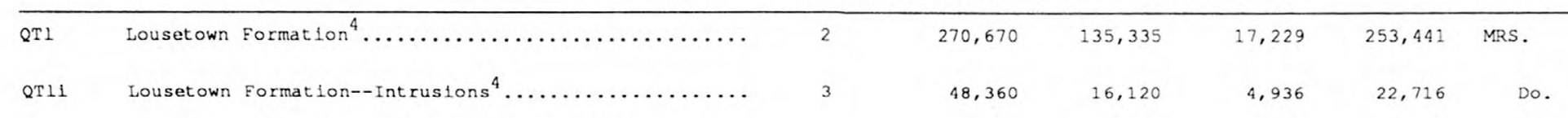




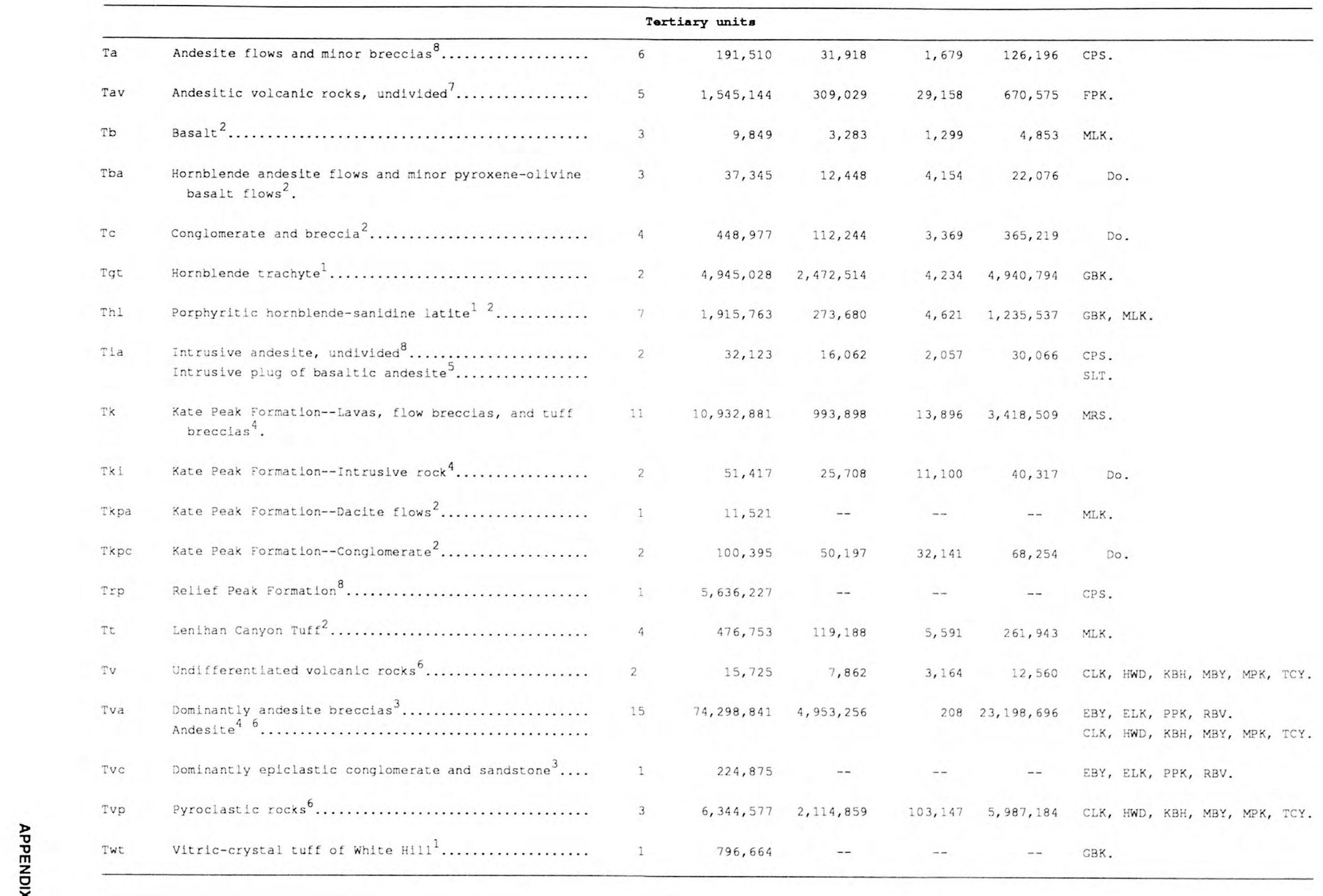


Table 8. Summary documentation for spatial data base GEOL COMP in Tahoe Environmental Geographic Information system-Continued

\begin{tabular}{|c|c|c|c|c|c|c|c|}
\hline \multicolumn{2}{|r|}{ Geologic or other map unit } & \multicolumn{5}{|c|}{ Occurrences } & \multirow{3}{*}{$\begin{array}{c}\text { Relevant } \\
\text { digitized } \\
1: 24,000-\text {-scale } \\
\text { topographic-map } \\
\text { quadrangles }\end{array}$} \\
\hline SYmbo! & \multirow{2}{*}{ Description } & \multirow{2}{*}{$\begin{array}{c}\text { Total } \\
\text { number } \\
\text { basinwide }\end{array}$} & \multicolumn{4}{|c|}{$\begin{array}{c}\text { Area } \\
\text { (square meters) }\end{array}$} & \\
\hline & & & $\begin{array}{l}\text { Basinwide } \\
\text { total }\end{array}$ & Mean & Minimum & Maximum & \\
\hline \multicolumn{8}{|c|}{ Mesozoic units, undivided } \\
\hline Mza & Alaskite $^{1} \ldots \ldots \ldots \ldots \ldots \ldots \ldots \ldots \ldots \ldots \ldots$ & 1 & 167,264 & -- & -- & -- & GBK. \\
\hline Mzag & Seriate aplitic granite to granodiorite ${ }^{2} \ldots \ldots \ldots \ldots$ & 5 & $5,070,534$ & $1,014,107$ & 57,555 & $2,718,338$ & MLK. \\
\hline Mzgd & Hornblende granodiorite ${ }^{2} \ldots$ & 1 & $1,660,412$ & -- & -- & -- & Do. \\
\hline Mzmc & Metaconglomerate and metasandstone ${ }^{1} \ldots \ldots \ldots \ldots \ldots \ldots$ & 3 & 906,338 & 302,113 & 75,852 & 746,539 & GBK. \\
\hline Mzmd & Hornblende diorite of Montreal Canyon ${ }^{1} \ldots \ldots \ldots \ldots \ldots$ & 3 & $1,223,709$ & 407,903 & 19,500 & $1,045,377$ & Do. \\
\hline Mzms & 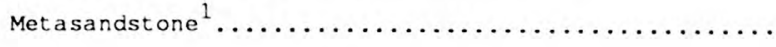 & 1 & 200,896 & -- & -- & -- & Do. \\
\hline Mzmv & Metamorphosed tuff and flows ${ }^{2}{ }^{2}$. & 10 & $8,948,337$ & 894,834 & 3,874 & $6,311,644$ & GBK，MLK. \\
\hline Mznm & Biotite monzogranite of North Logan House Creek ${ }^{1} \ldots \ldots$ & 1 & $3,631,046$ & -- & -- & -- & GBK. \\
\hline Mzqs & Quartzofeldspathic schist ${ }^{5} \ldots \ldots \ldots \ldots \ldots \ldots \ldots \ldots \ldots$ & 1 & $1,037,868$ & -- & -- & -- & SLT. \\
\hline Mzsm & $\begin{array}{l}\text { Biotite-hornblende monzogranite of spooner } \\
\text { sumit }{ }^{2} \text {. }\end{array}$ & 7 & $36,105,887$ & $5,157,984$ & 4,502 & $32,134,311$ & GBK, MLK. \\
\hline
\end{tabular}

Cretaceous units

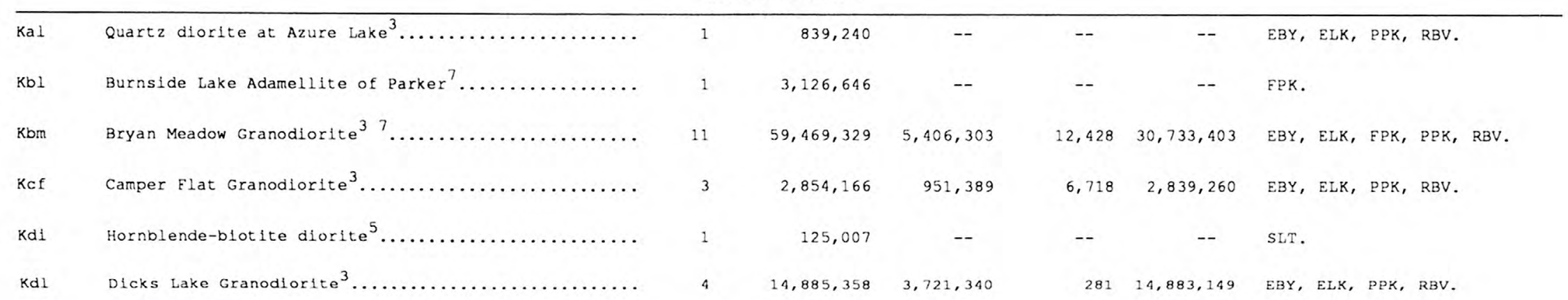




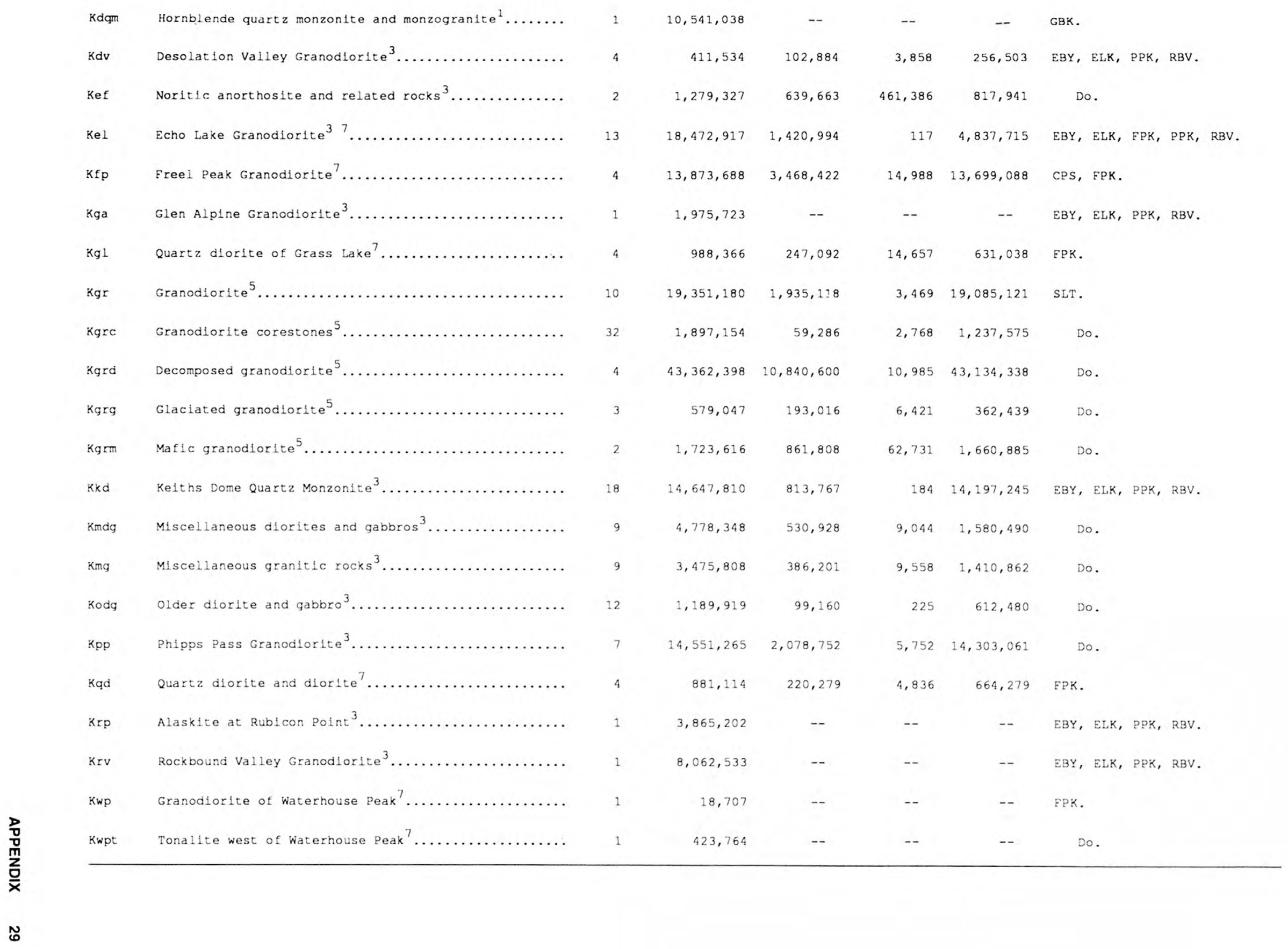


Tabl- 8. Summary documentation for spatial data base GEOL_COMP in Tahoe Environmental Geographic Information System-Continued

\begin{tabular}{|c|c|c|c|c|c|c|c|}
\hline \multicolumn{2}{|r|}{ Geologic or other map unit } & \multicolumn{5}{|c|}{ Occurrences } & \multirow{3}{*}{$\begin{array}{c}\text { Relevant } \\
\text { digitized } \\
1: 24,000-\text { scale } \\
\text { topographic-map } \\
\text { quadrangles }\end{array}$} \\
\hline & \multirow{2}{*}{ Description } & \multirow{2}{*}{$\begin{array}{c}\text { Total } \\
\text { number } \\
\text { basinwide }\end{array}$} & \multicolumn{4}{|c|}{$\begin{array}{c}\text { Area } \\
\text { (square meters) }\end{array}$} & \\
\hline Symbol & & & $\begin{array}{l}\text { Basinwide } \\
\text { total }\end{array}$ & Mean & Minimum & Maximum & \\
\hline \multicolumn{8}{|c|}{ Crotaceous units--Continued } \\
\hline Kydg & Younger diorite and gabbro ${ }^{3} \ldots \ldots \ldots \ldots \ldots \ldots \ldots$ & 6 & $1,700,379$ & 283,397 & 16,445 & $1,202,139$ & EBY, ELK, PPK, RBV. \\
\hline Kzqm & $\begin{array}{l}\text { Hornblende-blotite quartz monzodiorite and grano- } \\
\text { diorite of zephyr cove }{ }^{1} \text {. }\end{array}$ & 3 & $31,866,273$ & $10,622,091$ & $2,478,885$ & $22,949,712$ & GBK. \\
\hline
\end{tabular}

Jurassic and (or) Triassic units

\begin{tabular}{|c|c|c|c|c|c|c|c|c|}
\hline JTRaf & Basalt and pyroxene andesite flows ${ }^{3} \ldots \ldots \ldots \ldots \ldots \ldots$ & 8 & $2,272,111$ & 284,014 & 14,160 & 728,839 & EBY, ELK, PPK, & RBV. \\
\hline JTRbr & 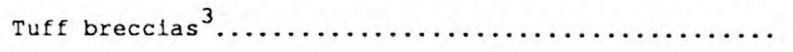 & 15 & $10,805,696$ & 720,380 & 6,585 & $5,415,647$ & Do. & \\
\hline JTRegl & Interbedded pebble and cobble conglomerate ${ }^{3} \ldots \ldots \ldots$ & 6 & $2,848,079$ & 474,680 & 9,723 & $1,428,209$ & Do. & \\
\hline JTRgm & Pyritic, graphitic mudstones ${ }^{3} \ldots \ldots \ldots \ldots \ldots \ldots \ldots$ & 2 & $1,938,974$ & 969,487 & 187,494 & $1,751,480$ & Do. & \\
\hline JTRms & $\begin{array}{l}\text { Miscellaneous metasedimentary } \text { rocks }^{3} \ldots \ldots \ldots \ldots \ldots \ldots \\
\text { Metasedimentary rocks }{ }^{7} \ldots \ldots \ldots \ldots \ldots \ldots \ldots \ldots\end{array}$ & 13 & $2,378,089$ & 182,930 & 1,304 & $1,112,029$ & $\begin{array}{l}\text { DO. } \\
\text { FPK. }\end{array}$ & \\
\hline JTRs & Tuffs and tuffaceous sandstones ${ }^{3} \ldots \ldots \ldots \ldots \ldots \ldots$ & 6 & $3,034,108$ & 505,685 & 611 & $1,263,533$ & EBY, ELK, PPK, & RBV. \\
\hline JTRss & Thin-bedded sandstones and siltstones ${ }^{3} \ldots \ldots \ldots \ldots \ldots$ & 4 & $1,246,870$ & 311,717 & 34,813 & 510,200 & Do. & \\
\hline \multicolumn{9}{|c|}{ Other map unit. } \\
\hline af & Artiflcial fill ${ }^{5} \ldots \ldots \ldots \ldots \ldots$ & 1 & 270,956 & -- & -- & -- & SLT. & \\
\hline ap & Aplite and (minor) pegmatites ${ }^{3} \ldots \ldots \ldots \ldots \ldots \ldots$ & 32 & 480,143 & 15,004 & 2,512 & 49,588 & EBY, ELK, PPK, & RBV. \\
\hline bd & Basalt dikes in granitic rocks ${ }^{3} \ldots \ldots \ldots \ldots \ldots \ldots \ldots$ & 5 & 105,858 & 21,172 & 7,290 & 39,683 & Do. & \\
\hline di & Intrusive rocks (diorite) ${ }^{6} \ldots \ldots \ldots \ldots \ldots \ldots \ldots \ldots \ldots$ & 1 & 4,026 & -- & -- & -- & CLK, HWD, KBH, & MBY, MPK, TCY. \\
\hline gd & 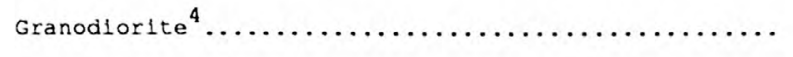 & 6 & $23,972,976$ & $3,995,496$ & 15,415 & $11,310,730$ & MRS. & \\
\hline gr, grd & 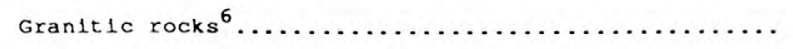 & 6 & $28,616,746$ & $4,088,106$ & 44.090 & $16,734,161$ & CLK, HWD, KBH, & MBY, MPK, TCY. \\
\hline
\end{tabular}


qu

WBDY
Undifferentiated metamorphic rocks ${ }^{6}$.

Mafic dikes in roof remnant ${ }^{3}$

Metasedimentary rocks ${ }^{6}$

No data ${ }^{6}$

Not mapped ${ }^{10}$

Quarry ${ }^{5}$
3

401,962

133,987

33,552

311,388

400,293

19,062

121

79,576

2

$5,070,549 \quad 2,535,275$

$18,964,293 \quad 3,792,859$

$1,076,627,616 \quad 53,831,381$

23,678

7,893

$512,924,631 \quad 1,318,572$
$273,355 \quad 4,797,195$

$14,304 \quad 17,707,041$

$125331,769,101$

4,332

13,102

$145282,936,951$
CLK, HWD, KBH, MBY, MPK, TCY.

EBY, ELK, PPK, RBV.

CLK, HWD, KBH, MBY, MPK, TCY.

CLK, HWD, KBH, MBY, MPK, TCY.

CLK, HWD, KBH, MBY, MPK, TCY.

SLT .

Al1 16 map quadrangles.

${ }^{1}$ Grose (1985).

${ }^{2}$ Grose (1986).

$3_{\text {Loomis (1981). }}$.

${ }^{4}$ Thompson and white (1964).

${ }^{5}$ Bonham and Burnett (1976).

Tahoe Regional Planning Agency natural-hazards map (Tahoe Regional Planning Agency, written commun., 1990).

7 Armin and John (1983).

${ }^{8}$ Armin and others, (1984).

${ }^{9}$ No data shown on source map.

${ }^{10}$ Outside basin boundary. 
Table 9. Summary documentation for spatial data base GEOL COMP LIN in Tahoe Environmental Geographic Information System

Description of coverage: Composite line coverage of linear geologic features Storage format: ARC/INFO

Data source: Digitized from eight geologic and related thematic maps (table 1)

Source scales: From 1:24,000 to $1: 125,000$

[Linear geologic feature: Symbol explanations are as used by authors of cited references and do not necessarily conform to U.S. Geological Survey usage]

\begin{tabular}{|c|c|c|c|c|c|}
\hline Linear geologic feature & \multirow{3}{*}{$\begin{array}{c}\text { Total } \\
\text { number } \\
\text { basinwide }\end{array}$} & \multicolumn{4}{|c|}{ Occurrences } \\
\hline & & \multirow[b]{2}{*}{$\begin{array}{c}\text { Basinwide } \\
\text { total }\end{array}$} & \multicolumn{2}{|c|}{$\begin{array}{c}\text { Length } \\
\text { (meters) }\end{array}$} & \multirow[b]{2}{*}{ Maximum } \\
\hline Explanation & & & Mean & Minimum & \\
\hline FLT $\ldots \ldots \ldots$ Eault $\ldots \ldots \ldots \ldots$ & 34 & 26,112 & 768 & 6 & 2,164 \\
\hline FLT-INTRP ... Interpretive fault.... & 88 & 90,005 & 1,023 & 27 & 3,506 \\
\hline FLT-CNCLD... Concealed fault....... & 65 & 112,812 & 1,736 & 50 & 26,797 \\
\hline MOR........ Moraine crest......... & 40 & 33,265 & 832 & 256 & 3,557 \\
\hline DIKE ...... Dike.............. & 34 & 4,502 & 132 & 67 & 465 \\
\hline SHEAR...... Shear zone.......... & 14 & 14,709 & 1,051 & 45 & 2,628 \\
\hline CONTACT.... Gradational contact.... & 3 & 7,838 & 2,613 & 1,605 & 3,792 \\
\hline
\end{tabular}


Table 10. Summary documentation for spatial data base GEOL_TRPA in Tahoe Environmental Geographic Information System

Description of coverage: Polygon coverage of geology

Storage format: ARC/INFO

Data source: Digitized from natural-hazards map (Tahoe Regional Planning Agency, written commun., 1990) Source scale: $1: 125,000$

Geologic or other map unit: Geologic symbols and unit descriptions are as used by Tahoe Regional Planning Agency and do not necessarily meet U.S. Geological Survey standards. Geologic map units are listed in alphanumeric order by map-unit symbol within major groups. Geologic units having no age information and other geologic, units are listed as other map units at end of table. --, not applicable!

\begin{tabular}{|c|c|c|c|c|c|c|}
\hline \multicolumn{2}{|r|}{ Geologic or other map unit } & \multicolumn{5}{|c|}{ Occurrences } \\
\hline \multirow{2}{*}{ Symbol } & \multirow{2}{*}{ Description } & \multirow{2}{*}{$\begin{array}{c}\text { Total } \\
\text { number } \\
\text { basinwide }\end{array}$} & \multicolumn{3}{|c|}{$\begin{array}{c}\text { Area } \\
\text { (square mecers) }\end{array}$} & \multirow[b]{2}{*}{ Maximum } \\
\hline & & & $\begin{array}{c}\text { Basinwide } \\
\text { total }\end{array}$ & Mean & Minimum & \\
\hline \multicolumn{7}{|c|}{ Quatemary units } \\
\hline Qal & Old lake sediment................... & 14 & $7,572,532$ & 540,895 & 8,722 & $3,776,621$ \\
\hline$Q q$ & Glacial outwash, undifferentiated........ & 14 & $30,940,481$ & $2,210,034$ & 781 & $11,109,767$ \\
\hline Q1 & 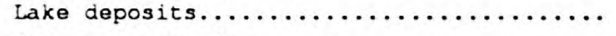 & 25 & $26,707,392$ & $1,068,296$ & 630 & $6,052,740$ \\
\hline Q10 & 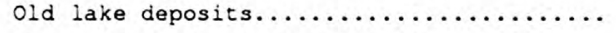 & 64 & $15,452,762$ & 241,449 & 5,868 & $5,016,079$ \\
\hline Q10, Qg & 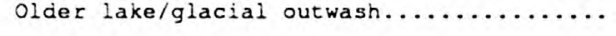 & 3 & $7,926,886$ & $2,642,295$ & 348,821 & $4,091,445$ \\
\hline Q1s & Landslide deposits $\ldots \ldots \ldots \ldots \ldots \ldots \ldots$ & 18 & $2,403,021$ & 133,501 & 23,076 & 735,602 \\
\hline Qm & Glacial moraine, undifferentiated........ & 12 & 992,632 & 82,719 & 11,385 & 226,038 \\
\hline Qm 1 & Glacial moraine--youngest............ & 1 & 520,632 & -- & -- & -- \\
\hline $0 \mathrm{~m} 2$ & 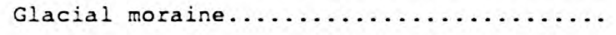 & 2 & $2,777,927$ & $1,388,964$ & 2,707 & $2,775,220$ \\
\hline Qm 3 & 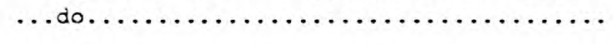 & 29 & $82,942,699$ & $2,860,093$ & 1,685 & $35,315,115$ \\
\hline Qm3-4 & 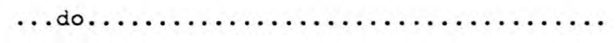 & 1 & 218,280 & -- & -- & -- \\
\hline Qm 4 & 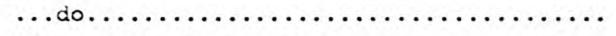 & 9 & $38,178,862$ & $4,242,096$ & 74,290 & $15,037,865$ \\
\hline Qm 5 & 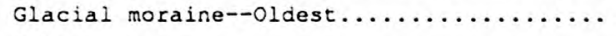 & 4 & $18,671,380$ & $4,667,845$ & 928,447 & $14,222,725$ \\
\hline Qta & 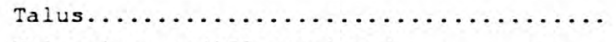 & 8 & $1,851,572$ & 231,446 & 7,261 & $1,450,886$ \\
\hline Qv & Volcanics, undifferentiated............. & 2 & $2,512,439$ & $1,256,219$ & 72,297 & $2,440,241$ \\
\hline Qvb & 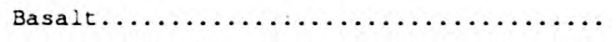 & 2 & 213,438 & 106,719 & 23,608 & 189,830 \\
\hline Qvi & Intrusive volcanic rocks, mainly latite... & 7 & $25,156,557$ & $3,593,794$ & 14,746 & $14,335,075$ \\
\hline \multicolumn{7}{|c|}{ Tertiary units } \\
\hline Tv & 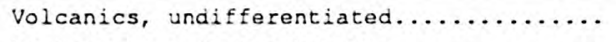 & 6 & $5,120,271$ & 853,379 & 12,560 & $4,732,904$ \\
\hline Tva & Dominantly andesite breccia........... & 23 & $94,492,699$ & $4,108,378$ & 15,932 & $27,330,965$ \\
\hline Tvp & 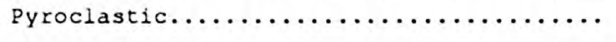 & 3 & $6,344,577$ & $2,114,859$ & 103,147 & $5,987,184$ \\
\hline \multicolumn{7}{|c|}{ Other map units } \\
\hline di & 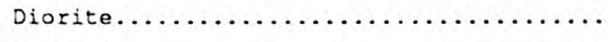 & 15 & $7,153,972$ & 476,931 & 9,716 & $1,591,922$ \\
\hline$g r$ & 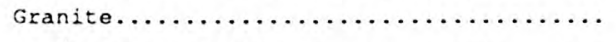 & 82 & $120,948,181$ & $1,474,978$ & 2,097 & $25,465,406$ \\
\hline grd & 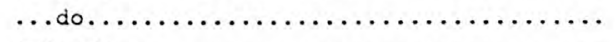 & 22 & $260,201,527$ & $11,827,342$ & 6,397 & $189,238,881$ \\
\hline ISLA & 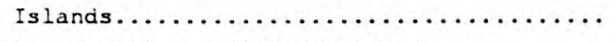 & 37 & 35,677 & 964 & 117 & 6,018 \\
\hline $\mathrm{m}$ & Metamorphic, undifferentiated.......... & 8 & $7,366,343$ & 920,793 & 2,716 & $5,275,681$ \\
\hline $\mathrm{ms}$ & 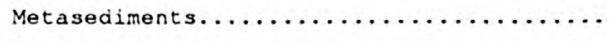 & 14 & $15,573,020$ & $1,112,359$ & 6,093 & $4,797,195$ \\
\hline $\mathrm{mv}$ & Metavolcanic rocks $\ldots \ldots \ldots \ldots \ldots \ldots \ldots$ & 9 & $14,804,631$ & $1,644,959$ & 9,185 & $14,354,541$ \\
\hline ND & 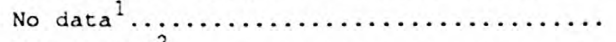 & 9 & $19,815,244$ & $2,201,694$ & 14,304 & $17,707,041$ \\
\hline NM & Not mapped ${ }^{2} \ldots \ldots \ldots \ldots \ldots \ldots \ldots$ & 1 & 28,892 & -- & -- & -- \\
\hline WBDY & 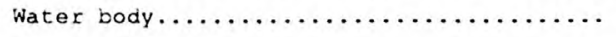 & 380 & $512,933,391$ & $1,349,825$ & 144 & $498,108,062$ \\
\hline
\end{tabular}

\footnotetext{
No data shown on source map.

${ }^{2}$ Outside basin boundary.
} 
Table 11. Summary documentation for spatial data base GEOL_TRPA_LIN in Tahoe Environmental Geographic Information system

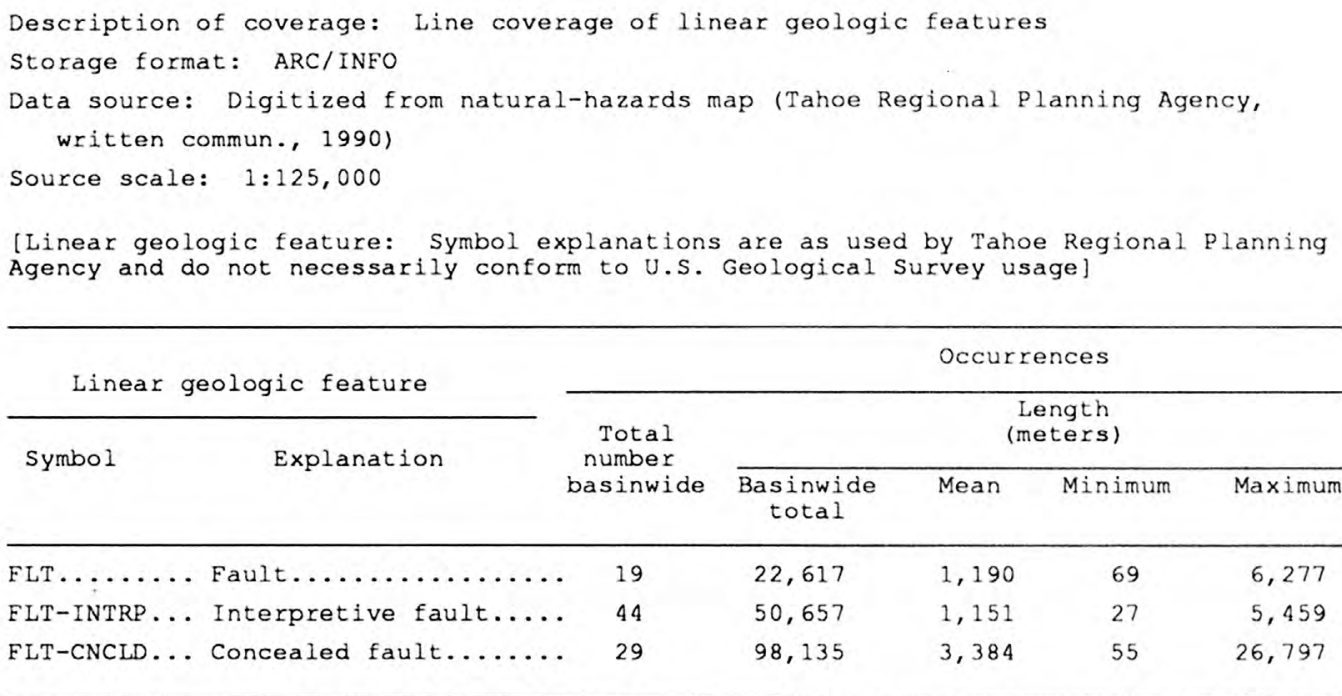


Table 12. Summary documentation for spatial data base HYD_BASIN in Tahoe Environmental Geographic Information System

Description of coverage: Polygon coverage of hydrography and hydrologic features Storage format: ARC/INFO

Data source: Digitized from hydrologic-basin boundaries delineated on U.S. Geological Survey topographic maps Source scale: $1: 24,000$

(Hydrographic map unit or site: Symbols (except 0 ) and descriptions were derived from Jorgensen and others (1978). Intervening area, area tributary to Lake Tahoe and lying between mouths of streams. --, not applicable]

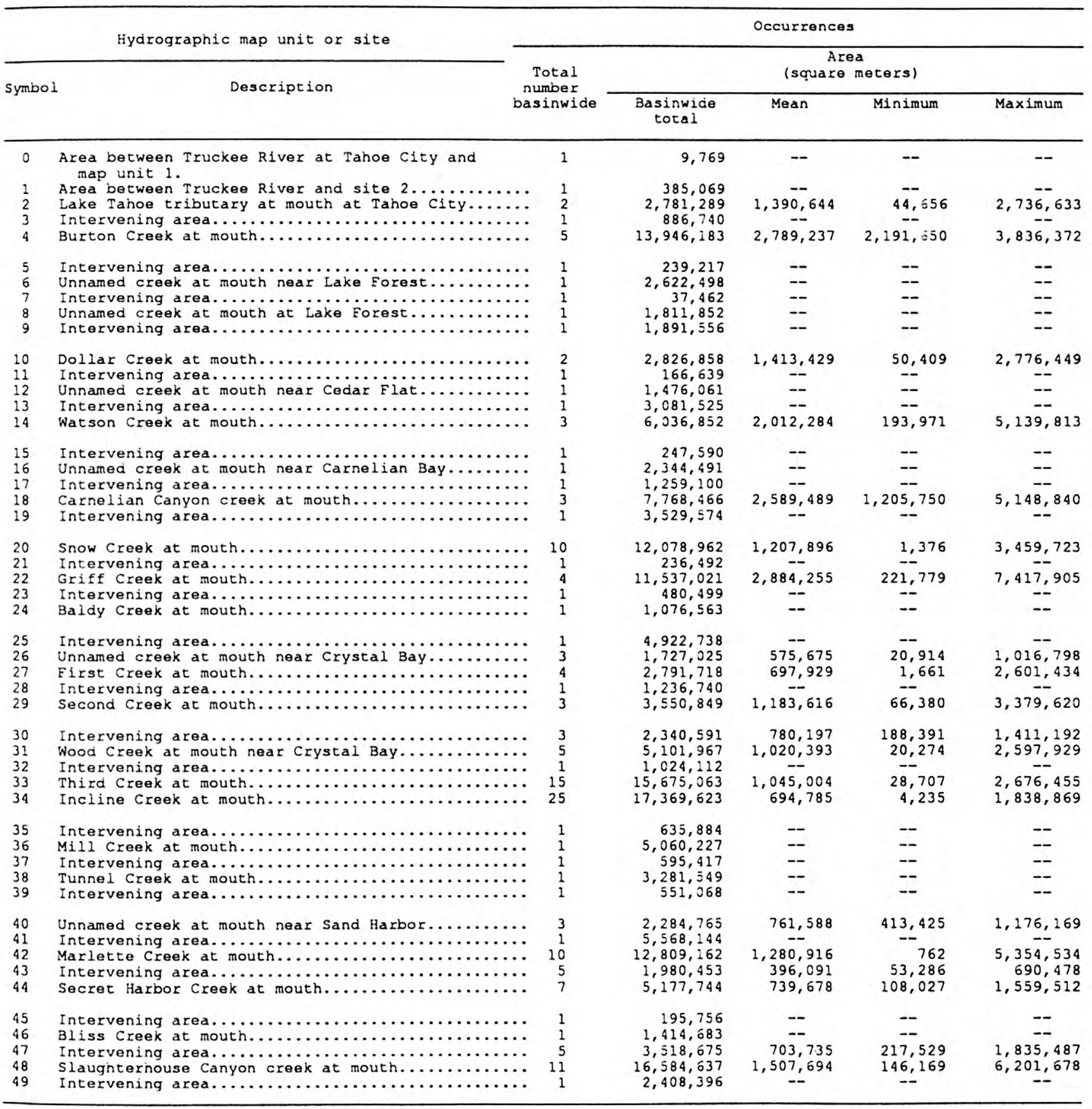


Table 12. Summary documentation for spatial data base HYD_BASIN in Tahoe Environmental Geographic Information System-Continued

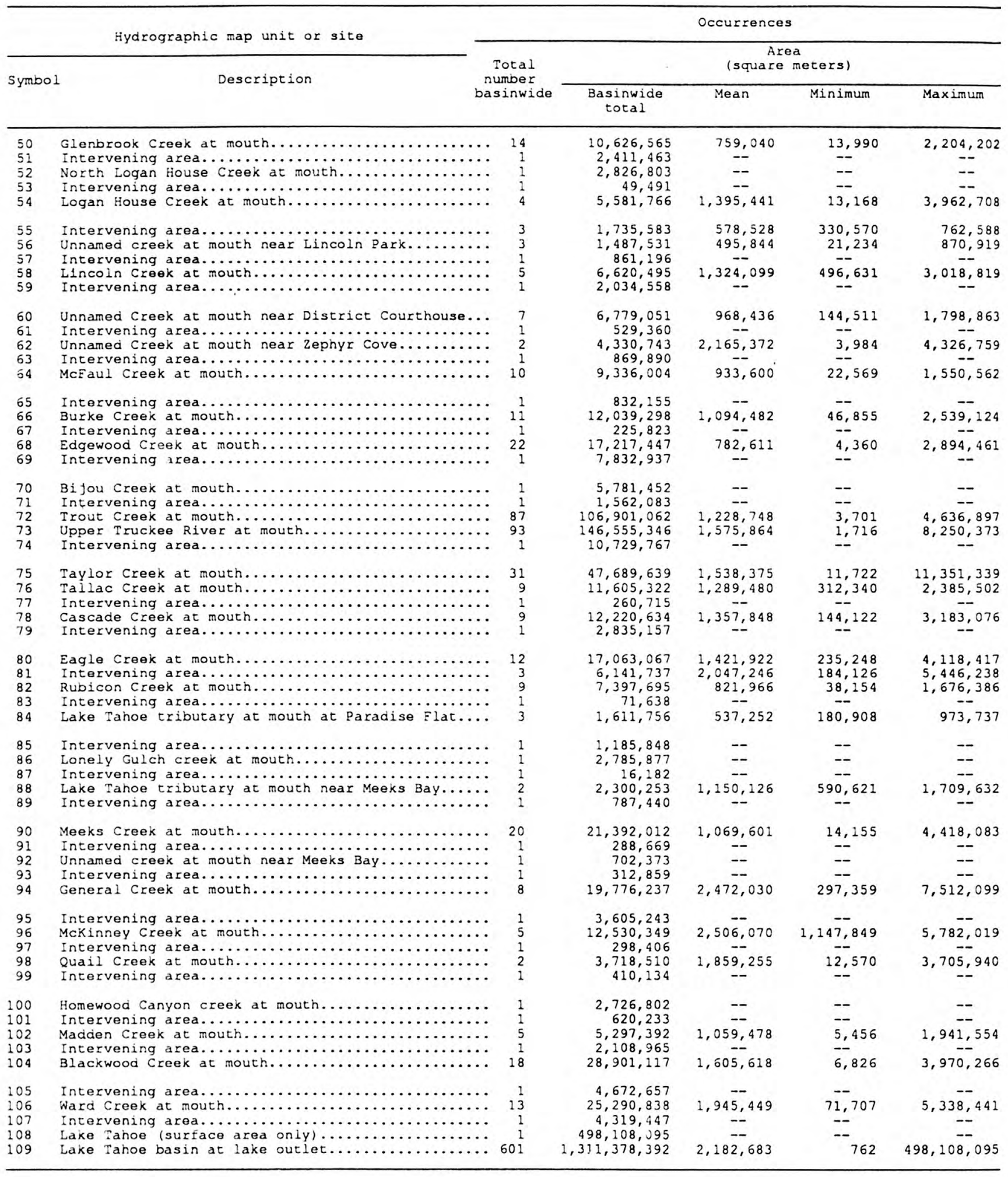


Table 13. Summary documentation for spatial data base LAND ASPECT in Tahoe Environmental Geographic Information system

Description of coverage: Polygon coverage of land aspect

Storage format: ARC/INFO

Data source: Derived from U.S. Geological Survey Digital Elevation Model

computer files

Source resolution: 30 by 30 meters

\begin{tabular}{|c|c|c|c|c|c|c|}
\hline \multicolumn{2}{|c|}{ Land-aspect map unit } & \multicolumn{5}{|c|}{ Occurrences } \\
\hline \multirow{2}{*}{ Symbol } & \multirow{2}{*}{ Description } & \multirow{2}{*}{$\begin{array}{c}\text { Total } \\
\text { number } \\
\text { basinwide }\end{array}$} & \multicolumn{4}{|c|}{$\begin{array}{c}\text { Area } \\
\text { (square meters) }\end{array}$} \\
\hline & & & $\begin{array}{c}\text { Basinwide } \\
\text { total }\end{array}$ & Mean & Minimum & Maximum \\
\hline 0 & Level......... & 4,106 & $630,350,723$ & 153,519 & $<1$ & $498,108,075$ \\
\hline 1 & North........ & 559 & $8,337,992$ & 14,916 & $<1$ & $1,380,690$ \\
\hline 2 & Northeast...... & 3,236 & $81,917,868$ & 25,314 & $<1$ & $1,649,189$ \\
\hline 3 & East........ & 3,021 & $95,306,746$ & 31,548 & $<1$ & $2,271,319$ \\
\hline 4 & Southeast...... & 3,109 & $103,969,010$ & 33,441 & $<1$ & $2,313,061$ \\
\hline 5 & south........ & 2,764 & $101,169,657$ & 36,602 & $<1$ & $4,908,139$ \\
\hline 6 & Southwest...... & 2,728 & $84,453,074$ & 30,958 & $<1$ & $2,088,365$ \\
\hline 7 & West........ & 2,951 & $85,663,363$ & 29,029 & 2 & $1,997,659$ \\
\hline 8 & Northwest...... & 3,313 & $120,872,256$ & 36,484 & $<1$ & $6,005,375$ \\
\hline
\end{tabular}

Tablo 14. Summary documentation for spatial data base LAND SLOpE in Tahoe Environmental Geographic Information System

Description of coverage: Polygon coverage of land slope Storage format: ARC/INFO

Data source: Derived from U.S. Geological Survey Digital Elevation Model computer files Source resolution: 30 by 30 meters

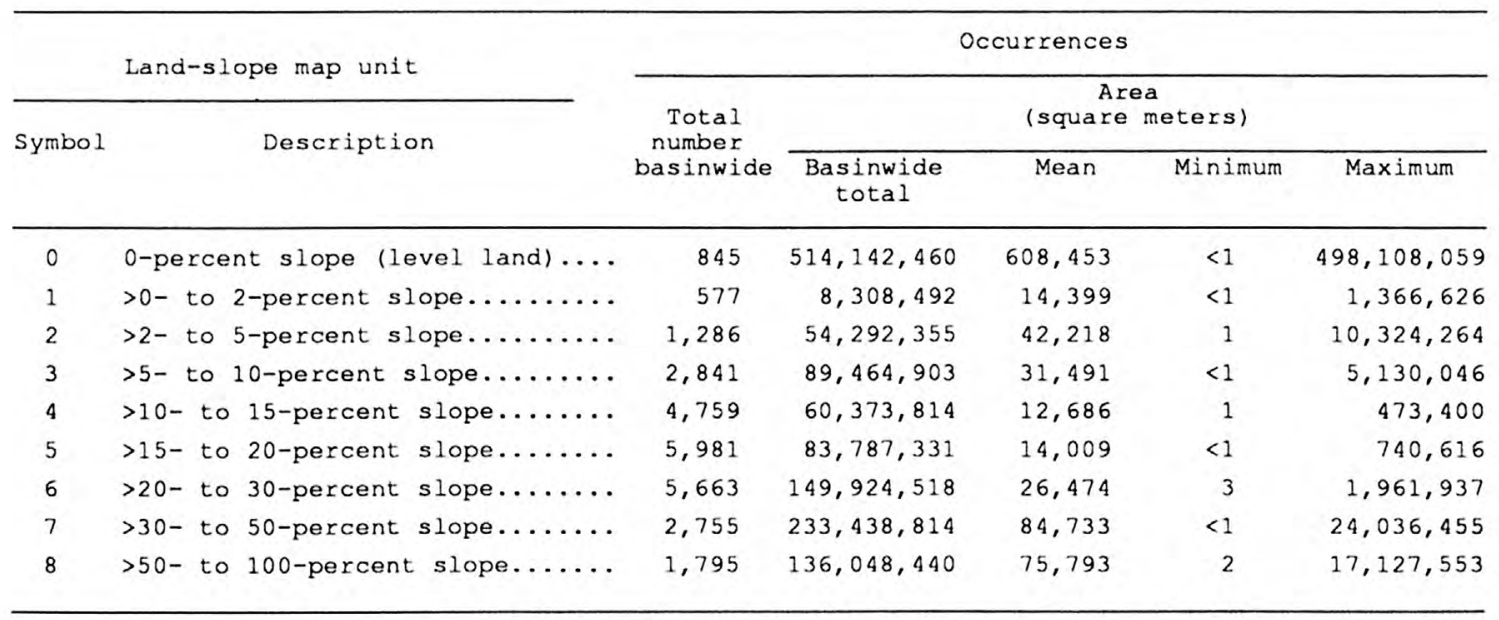


Table 15. Summary documentation for spatial data base LAND CAP in Tahoe Environmental Geographic Information System

Description of coverage: Polygon coverage of land capability (based on Bailey, 1974) Storage format: ARC/INFO

Data source: Derived from SOIL coverage (table 18)

Source scale: $1: 24,000$

[do., ditto; --, not applicable]

\begin{tabular}{|c|c|c|c|c|c|c|}
\hline \multirow{2}{*}{\multicolumn{2}{|c|}{ Land-capability map unit }} & \multicolumn{5}{|c|}{ Occurrences } \\
\hline & & \multirow{2}{*}{$\begin{array}{c}\text { Total } \\
\text { number } \\
\text { basinwide }\end{array}$} & \multicolumn{4}{|c|}{$\begin{array}{c}\text { Area } \\
\text { (square meters) }\end{array}$} \\
\hline Symbol & Description & & $\begin{array}{c}\text { Basinwide } \\
\text { total }\end{array}$ & Mean & Minimum & Maximum \\
\hline $1 \mathrm{a}$ & High-hazard lands......... & 128 & $298,340,933$ & $2,330,789$ & 15,450 & $149,890,244$ \\
\hline $1 b$ & ..do.............. & 167 & $42,015,992$ & 251,593 & 3,223 & $20,200,895$ \\
\hline $1 c$ & $\ldots$ do............... & 220 & $223,463,508$ & $1,015,743$ & 432 & $86,465,536$ \\
\hline 2 & $\ldots$ do............... & 129 & $42,992,984$ & 333,279 & 12,941 & $3,697,263$ \\
\hline 3 & Moderate-hazard lands...... & 129 & $54,321,738$ & 421,099 & 18,480 & $6,055,268$ \\
\hline 4 & $\ldots$ do.................. & 105 & $30,868,517$ & 293,986 & 14,943 & $3,216,385$ \\
\hline 5 & Low-hazard lands........... & 106 & $72,478,823$ & 683,762 & 14,174 & $14,566,318$ \\
\hline 6 & $\ldots$ do.............. & 72 & $36,430,047$ & 505,973 & 20,861 & $6,815,395$ \\
\hline 7 & $\ldots$ do $\ldots \ldots \ldots \ldots \ldots \ldots \ldots$ & 20 & $13,624,826$ & 681,241 & 28,723 & $3,561,517$ \\
\hline ND & 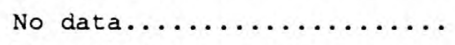 & 1 & 84,016 & -- & -- & -- \\
\hline WB & 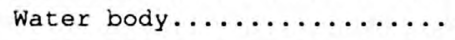 & 376 & $512,969,887$ & $1,364,282$ & 144 & $498,518,930$ \\
\hline
\end{tabular}


Table 16. Summary documentation for spatial data base MONITOR_SITE in Tahoe Environmental Geographic Information system

Description of coverage: Point coverage

Storage format: ARC/INFO

Data source: Derived from monitoring-site locations marked on 1:24,000-scale topographic maps by Lahontan Water Quality Control Board, Nevada Department of Environmental Protection, U.S. Forest Service, U.S. Geological Survey, and U.S. Soil Conservation Service Source scale: 1:24,000

[GIS, geographic information system. SNOTEL, U.S. Soil Conservation Service snowpack-telemetry site]

\begin{tabular}{ccc}
\hline GIS \\
attribute \\
\cline { 2 - 2 } $\begin{array}{c}\text { label for } \\
\text { type of } \\
\text { site }\end{array}$ & Description & $\begin{array}{c}\text { Total } \\
\text { number } \\
\text { basinwide }\end{array}$ \\
\hline
\end{tabular}

Iahontan Water Quality Control Board sites

\begin{tabular}{|c|c|c|}
\hline GW & $\begin{array}{l}\text { Ground-water-monitoring station } \\
\text { Surface-water-monitoring station }\end{array}$ & $\begin{array}{l}4 \\
4\end{array}$ \\
\hline Novada & Department of Environmental Protection & attes \\
\hline $\begin{array}{l}\text { GW } \\
\text { SW }\end{array}$ & $\begin{array}{l}\text { Ground-water-monitoring station } \\
\text { Surface-water-monitoring station }\end{array}$ & $\begin{array}{l}12 \\
12\end{array}$ \\
\hline \multicolumn{3}{|c|}{ U.S. Forest Service sites } \\
\hline $\begin{array}{l}\text { LK } \\
\text { SP } \\
\text { SW }\end{array}$ & $\begin{array}{l}\text { Lake-monitoring station } \\
\text { Spring-monitoring station } \\
\text { Surface-water-monitoring station }\end{array}$ & $\begin{array}{r}9 \\
3 \\
47\end{array}$ \\
\hline \multicolumn{3}{|c|}{ U.S. Geological Survey sites } \\
\hline $\begin{array}{l}\text { GW } \\
\text { SW } \\
\text { QW } \\
\text { LK }\end{array}$ & $\begin{array}{l}\text { Ground-water-monitoring station } \\
\text { Surface-water-monitoring station } \\
\text { Water-quality-monitoring station } \\
\text { Lake-monitoring station }\end{array}$ & $\begin{array}{r}30 \\
73 \\
63 \\
3\end{array}$ \\
\hline \multicolumn{3}{|c|}{ U.S. Soll Conservation Service sites } \\
\hline $\begin{array}{l}\text { P } \\
S \\
S P \\
T\end{array}$ & $\begin{array}{l}\text { Precipitation-monitoring station } \\
\text { Snow-course site } \\
\text { Spring-monitoring station } \\
\text { SNOTEL station }\end{array}$ & $\begin{array}{r}8 \\
8 \\
20 \\
8\end{array}$ \\
\hline
\end{tabular}


Table 17. Summary documentation for spatial data base RIPARIAN_VEG in Tahoe Environmental Geographic Information System

Description of coverage: Polygon coverage of riparian vegetation Storage format: ARC/INFO

Data source: Digitized from U.S. Forest Service riparian-vegetation maps

Source scale: $1: 24,000$

[--, not applicable]

\begin{tabular}{|c|c|c|c|c|c|c|}
\hline \multirow{2}{*}{\multicolumn{2}{|c|}{ Riparian-vegetation map unit }} & \multicolumn{5}{|c|}{ Occurrences } \\
\hline & & \multirow{2}{*}{$\begin{array}{c}\text { Total } \\
\text { number } \\
\text { basinwide }\end{array}$} & \multicolumn{4}{|c|}{$\begin{array}{c}\text { Area } \\
\text { (square meters) }\end{array}$} \\
\hline Symbol & Description & & $\begin{array}{c}\text { Basinwide } \\
\text { total }\end{array}$ & Mean & Minimum & Maximum \\
\hline 1 & Coniferous riparian............ & 1,845 & $27,413,550$ & 14,298 & 49 & 505,427 \\
\hline 2 & Deciduous riparian............ & 2,103 & $18,592,777$ & 8,576 & 499 & 216,928 \\
\hline 3 & Deciduous/coniferous riparian..... & 1,168 & $12,476,827$ & 10,611 & 686 & 153,755 \\
\hline 4 & Wet meadow $\ldots \ldots \ldots \ldots \ldots \ldots \ldots \ldots$ & 486 & $8,045,592$ & 15,663 & 327 & 986,980 \\
\hline 5 & Moist meadow............... & 460 & $6,729,732$ & 12,658 & 128 & 445,731 \\
\hline 6 & 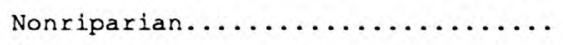 & 172 & $3,486,357$ & 19,435 & 780 & 723,719 \\
\hline 7 & Water $\ldots \ldots \ldots \ldots \ldots \ldots \ldots \ldots$ & 68 & $1,649,531$ & 21,119 & 806 & 375,405 \\
\hline 8 & No data (no label on source map)... & 1 & 10,773 & -- & -- & -- \\
\hline 9 & $\begin{array}{l}\text { Mixed unit (multiple labels on } \\
\text { source map). }\end{array}$ & 4 & 38,640 & 6,440 & 2,973 & 25,323 \\
\hline
\end{tabular}


Taile 18. Summary documentation for spatial data base soll in Tahoe Environmental Geographic Information System Description of coverage: Polygon coverage of soil types Storage format: ARC/INFO

Data source: Digitized from U.S. Soil Conservation Service soil survey (Rogers, 1974) Source scale: $1: 24,000$

[Except for ISLA and WBDY, symbols and descriptions for soil map units are as used by Rogers (1974) and do not necessarily conform to U.S. Geological Survey nomenclature standards. --, not applicable

\begin{tabular}{|c|c|c|c|c|c|c|}
\hline \multicolumn{2}{|r|}{ Soil or other map unit } & \multicolumn{5}{|c|}{ Occurrences } \\
\hline \multirow{2}{*}{ Symbol } & \multirow{2}{*}{ Description } & \multirow{2}{*}{$\begin{array}{c}\text { Total } \\
\text { number } \\
\text { basinwide }\end{array}$} & \multicolumn{4}{|c|}{$\begin{array}{c}\text { Area } \\
\text { (square meters) }\end{array}$} \\
\hline & & & $\begin{array}{l}\text { Basinwide } \\
\text { total }\end{array}$ & \multirow{2}{*}{$\begin{array}{c}\text { Mean } \\
121,834\end{array}$} & \multirow{2}{*}{$\begin{array}{r}\text { Minimum } \\
15,987\end{array}$} & \multirow{2}{*}{$\begin{array}{r}\text { Maximum } \\
402,786\end{array}$} \\
\hline $\mathrm{Be}$ & 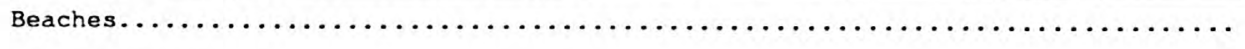 & 10 & $1,218,335$ & & & \\
\hline $\mathrm{CaD}$ & 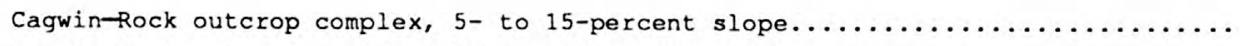 & 44 & $9,045,353$ & 205,576 & 14,943 & $1,499,938$ \\
\hline $\mathrm{CaE}$ & 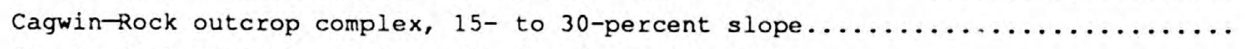 & 101 & $34,091,781$ & 337,542 & 8,543 & $2,954,853$ \\
\hline $\mathrm{CaF}$ & 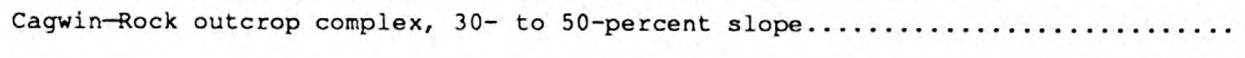 & 67 & $62,892,845$ & 938,699 & 29,772 & $13,735,058$ \\
\hline Co & 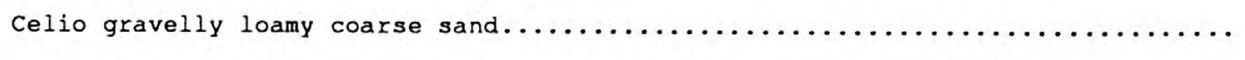 & 7 & $5,525,791$ & 789,399 & 15,318 & $4,344,123$ \\
\hline $\mathrm{EbC}$ & 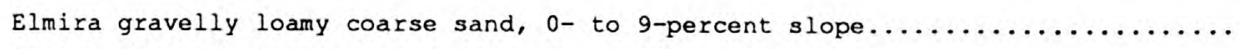 & 10 & $1,495,364$ & 149,536 & 71,217 & 361,960 \\
\hline EbE & Elmira gravelly loamy coarse sand, 9- to 30 -percent slope $\ldots \ldots \ldots \ldots \ldots \ldots \ldots$ & 7 & $2,969,559$ & 424,223 & 44,458 & $1,728,816$ \\
\hline EcE & 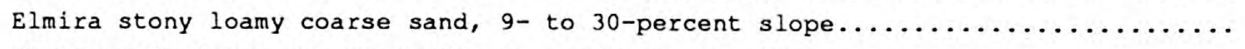 & 5 & $1,560,136$ & 312,027 & 141,791 & 460,794 \\
\hline EfB & Elmira-Gefo loamy coarse sands, 0 - to 5 -percent slope $\ldots \ldots \ldots \ldots \ldots \ldots \ldots \ldots \ldots \ldots \ldots \ldots \ldots$ & 20 & $13,624,826$ & 681,241 & 28,723 & $3,561,517$ \\
\hline Ev & 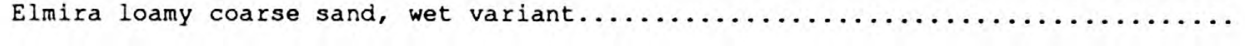 & 37 & $9,113,008$ & 246,298 & 13,103 & $3,004,640$ \\
\hline $\mathrm{Fd}$ & 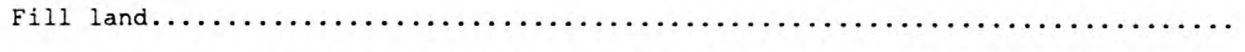 & 4 & $1,518,353$ & 379,588 & 844 & $1,451,441$ \\
\hline FuD & Fugawee very stony sandy loam, 2 - to 15 -percent slope $\ldots \ldots \ldots \ldots \ldots \ldots \ldots \ldots$ & 18 & $5,306,104$ & 294,784 & 9,973 & $1,364,941$ \\
\hline FUE & Fugawee very stony sandy loam, 15 - to 30 -percent slope $\ldots \ldots \ldots \ldots \ldots \ldots \ldots \ldots$ & 4 & $1,111,941$ & 277,985 & 40,188 & 564,590 \\
\hline $\mathrm{GeC}$ & 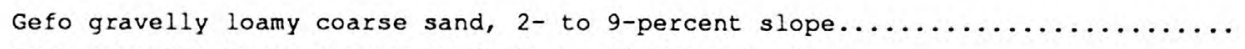 & 17 & $3,754,811$ & 220,871 & 41,008 & 555,601 \\
\hline GeD & 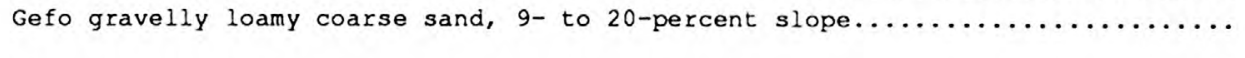 & 4 & 904,319 & 226,080 & 106,619 & 508,949 \\
\hline Gr & 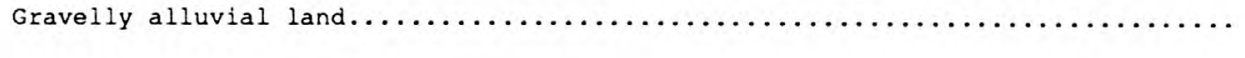 & 57 & $7,215,385$ & 126,586 & 3,223 & $1,073,126$ \\
\hline GsE & Graylock extremely stony loamy coarse sand, 30 - to 50 -percent slope............ & 7 & $9,631,117$ & $1,375,874$ & 82,650 & $2,731,589$ \\
\hline
\end{tabular}


Table 18. Summary documentation for spatial data base SOIL in Tahoe Environmental Geographic Information System-Continued

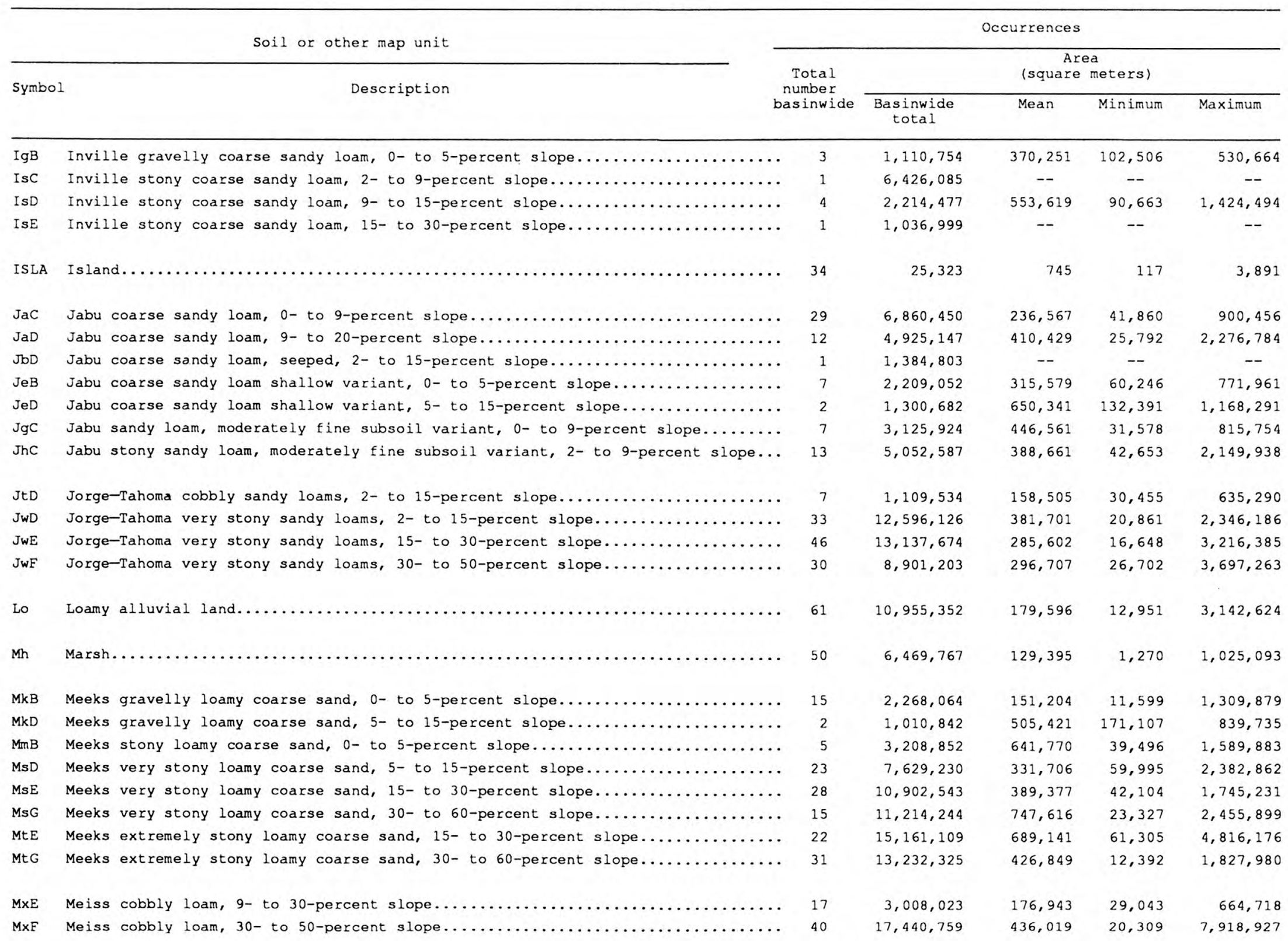


$97,144,124$

574,817

$18,745,885$

781,079

432

$10,020,058$

626,254

98,772

$13,853,773$

$40,338,814$

$19,629,196$

310,299

36,683

892,236

15,450

61,512

3,353

$4,976,299$

$1,119,853$

$2,488,149$

159,979

170,653

77,932

272,980

10,454

306,622

$6,132,431$

$4,915,697$

409,641

25,791

72,809

$11,053,492$

$9,886,252$

850,269

659,083

$10,925,744$

$12,916,468$

546,287

461,302

$8,246,059$

$5,417,774$

485,062

601,975

477,397

$3,341,777$

$3,133,210$

447,601

$3,313,749$

$20,157,104$

194,926

719,897

$6,053,772$

252,24

286,309

$12,883,920$

$24,096,314$

688,466

$7,930,471$

$2,959,357$

466,498

269,032

322,823

662,134

72,222

58,612

34,157

18,480

74,737

39,496

102,528

39,724

091,307

$3,762,676$

$5,237,385$

$45,821,422$

$4,805,646$

375,818

\section{$1,946,629$}

$1,259,376$

$1,290,723$

$5,043,014$

$4,144,000$

$5,029,730$

$1,850,218$

$3,145,692$

$2,475,361$

$2,112,006$

$1,612,790$

$20,224 \quad 658,038$

$50,209 \quad 8,365,166$

$14,174 \quad 2,358,955$

$26,132 \quad 1,344,139$

$24,411 \quad 3,197,559$

$3,228,233$

114,057

$1,907,904$

$15,229,075$

54,071

781,754

$39,202 \quad 1,207,493$

$34,041 \quad 5,134,020$ 
Table 19. Summary documentation for spatial data base TIMBER_TYPE in Tahoe Environmental Geographic Information System

Description of coverage: Polygon coverage of timier classes

Storage format: ARC/INEO

Data source: Digitized froin U.S. Forest Service cimber-type maps

Source scale: $1: 24,000$

(Timber-type map unit: Except for ISLA and WBDY, symbols are those used on U.S. Forest Service timber-type maps (Joseph Oden, written commun., 1992); see table 2 for explanation of alphanumeric symbols and for more detailed classification basis. do., ditto; --, not applicable]

Timber-type map unit

Symbol Main classification basis $\quad \begin{gathered}\text { Total } \\ \text { number }\end{gathered}$ (square meters)

Woody-vegetation areas

\begin{tabular}{|c|c|c|c|c|c|c|}
\hline HA & 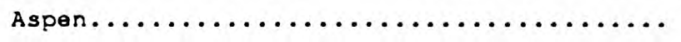 & 56 & $7,230,894$ & 129,123 & 6,252 & 478,131 \\
\hline $\mathrm{HX}$ & 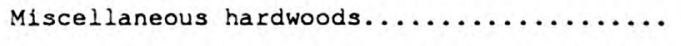 & 10 & 670,455 & 67,045 & 23,817 & 157,873 \\
\hline $\begin{array}{l}\text { IP IG } \\
\text { LPIN } \\
\text { LP 2G } \\
\text { LP 2N } \\
\text { LP 2P }\end{array}$ & 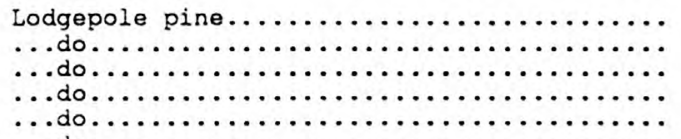 & $\begin{array}{r}1 \\
1 \\
35 \\
62 \\
70\end{array}$ & $\begin{array}{r}64,857 \\
61,701 \\
4,670,037 \\
8,252,609 \\
9,900,315\end{array}$ & $\begin{array}{l}133, \overline{-} \\
1330 \\
141,433\end{array}$ & $\begin{array}{r}14,010 \\
6,723 \\
11,245\end{array}$ & $\begin{array}{r}-\overline{-} \\
636, \overline{370} \\
679,102 \\
1,066,961\end{array}$ \\
\hline $\begin{array}{l}\text { LP } 2 P / S C \\
\text { LP2P/SR } \\
\text { LP2S } \\
\text { LP } 2 S / G L\end{array}$ & 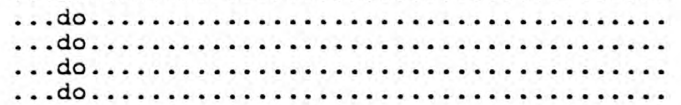 & $\begin{array}{r}1 \\
62 \\
1\end{array}$ & $\begin{array}{r}295,095 \\
25,289 \\
11,974,129 \\
122,944\end{array}$ & $193, \overline{-}$ & $10, \overline{3} 49$ & $1,442,100$ \\
\hline $\begin{array}{l}\text { LP2S/NG } \\
\text { LP2S/SC } \\
\text { LP2S/SM } \\
\text { LP 3G } \\
\text { LP 3N } \\
\text { LP 3P }\end{array}$ & 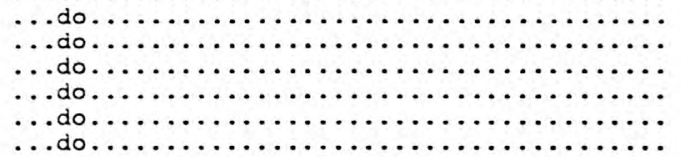 & $\begin{array}{r}3 \\
3 \\
2 \\
54 \\
110 \\
130\end{array}$ & $\begin{array}{r}734,975 \\
453,533 \\
313,204 \\
6,849,451 \\
18,618,320 \\
20,139,978\end{array}$ & $\begin{array}{l}244,992 \\
151,178 \\
156,602 \\
126,842 \\
169,257 \\
154,923\end{array}$ & $\begin{array}{r}160,163 \\
126,268 \\
132,410 \\
19,351 \\
17,499 \\
7,934\end{array}$ & $\begin{array}{r}292,738 \\
199,555 \\
180,794 \\
521,283 \\
897,797 \\
1,138,746\end{array}$ \\
\hline $\begin{array}{l}\text { LP } 3 P / N G \\
\text { LP } 3 S \\
\text { LP } 3 S / N C \\
\text { LP } 3 S / N G \\
\text { LP } 3 S / S C \\
\text { LP } 3 S / S R\end{array}$ & 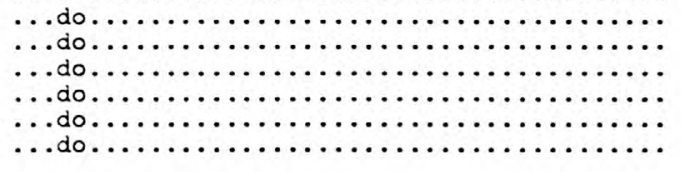 & $\begin{array}{r}1 \\
52 \\
1 \\
4 \\
5 \\
6\end{array}$ & $\begin{array}{r}144,765 \\
822,261 \\
72,680 \\
938,785 \\
1,052,821 \\
632,941\end{array}$ & $\begin{array}{l}161,967 \\
234,696 \\
210,564 \\
105,490\end{array}$ & $\begin{array}{l}18,064 \\
43,472 \\
68,215 \\
69,957\end{array}$ & $\begin{array}{r}1,063,003 \\
544,583 \\
361,073 \\
161,186\end{array}$ \\
\hline $\begin{array}{l}\text { LPHA3G } \\
\text { LPHA3N } \\
\text { LPHA3P } \\
\text { LPHA3S/SR }\end{array}$ & 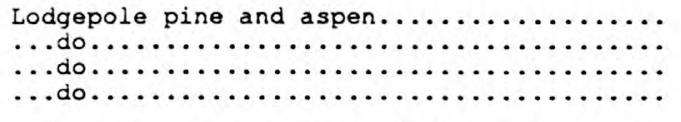 & $\begin{array}{l}1 \\
1 \\
2 \\
1\end{array}$ & $\begin{array}{r}111,987 \\
88,927 \\
264,356 \\
164,656\end{array}$ & $\begin{array}{c}-- \\
132,178 \\
=-\end{array}$ & $\begin{array}{c}-- \\
127, \overline{717} \\
=-\end{array}$ & $\begin{array}{c}-- \\
\overline{--} \\
136,639 \\
--\end{array}$ \\
\hline $\begin{array}{l}\text { LPMH } 2 \mathrm{G} \\
\text { LPMH } 2 \mathrm{~N} \\
\text { LPMH } 2 \text { P } \\
\text { LPMH } 2 \text { S } \\
\text { LPMH 3G } \\
\text { LPMH } 3 \mathrm{~N} \\
\text { LPMH } 3 P\end{array}$ & 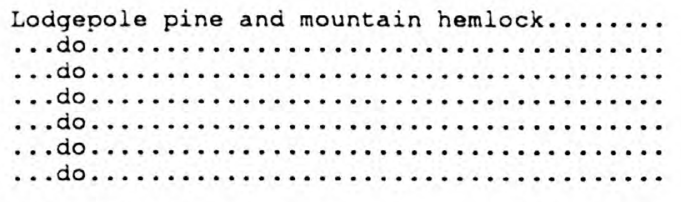 & $\begin{array}{r}1 \\
3 \\
3 \\
2 \\
5 \\
17 \\
9\end{array}$ & $\begin{array}{r}102,933 \\
304,260 \\
229,791 \\
382,063 \\
869,417 \\
1,482,116 \\
991,861\end{array}$ & $\begin{array}{r}101,420 \\
76,597 \\
191,032 \\
173,883 \\
87,183 \\
110,207\end{array}$ & $\begin{array}{r}64,270 \\
40,017 \\
92,702 \\
58,048 \\
5,791 \\
65,982\end{array}$ & $\begin{array}{l}170,108 \\
126,373 \\
289,361 \\
284,085 \\
233,228 \\
197,430\end{array}$ \\
\hline LPPP $2 \mathrm{~N}$ & $\begin{array}{l}\text { Lodgepole pine and ponderosa or Jeffrey } \\
\text { pine. }\end{array}$ & 1 & 66,349 & -- & -- & -- \\
\hline $\begin{array}{l}\text { LPPP } 2 \text { P } \\
\text { LPPP } 3 G \\
\text { LPPP } 3 N \\
\text { LPPP 3P } \\
\text { LPPP } 35\end{array}$ & 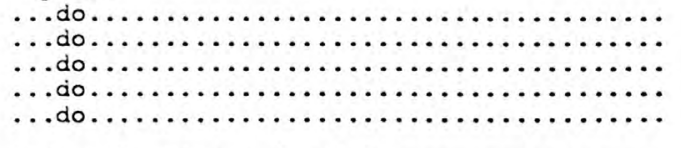 & $\begin{array}{r}1 \\
11 \\
21 \\
5 \\
4\end{array}$ & $\begin{array}{r}256,413 \\
1,598,467 \\
3,542,729 \\
517,001 \\
688,089\end{array}$ & $\begin{array}{c}14,- \\
145,315 \\
168,701 \\
103,400 \\
172,022\end{array}$ & $\begin{array}{r}29,-369 \\
746 \\
67,695 \\
52,487\end{array}$ & $\begin{array}{c}-- \\
314,276 \\
517,148 \\
183,255 \\
309,920\end{array}$ \\
\hline $\begin{array}{l}\text { LPRE } 2 \mathrm{~N} \\
\text { LPRE } 2 \text { P } \\
\text { LPRF } 3 \mathrm{G} \\
\text { LPRE } 3 \mathrm{~N} \\
\text { LPRF } 3 P \\
\text { LPRF } 3 \mathrm{~S} \\
\text { LPRE } 3 \mathrm{~S} / \mathrm{SR}\end{array}$ & 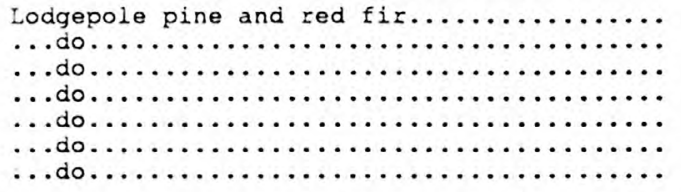 & $\begin{array}{r}1 \\
5 \\
13 \\
43 \\
29 \\
8 \\
1\end{array}$ & $\begin{array}{r}55,895 \\
1,571,559 \\
2,205,993 \\
6,511,481 \\
6,193,833 \\
1,567,098 \\
257,233\end{array}$ & $\begin{array}{c}-- \\
314,312 \\
169,692 \\
151,430 \\
213,580 \\
195,887 \\
--\end{array}$ & $\begin{array}{r}122,223 \\
43,085 \\
3,546 \\
13,995 \\
102,841 \\
--\end{array}$ & $\begin{array}{r}508,805 \\
421,177 \\
446,526 \\
1,109,435 \\
317,624 \\
\ldots-\end{array}$ \\
\hline
\end{tabular}


Table 19. Summary documentation for spatial data base TIMBER_TYPE in Taroe Environmental Geographic Infomation system-Continued

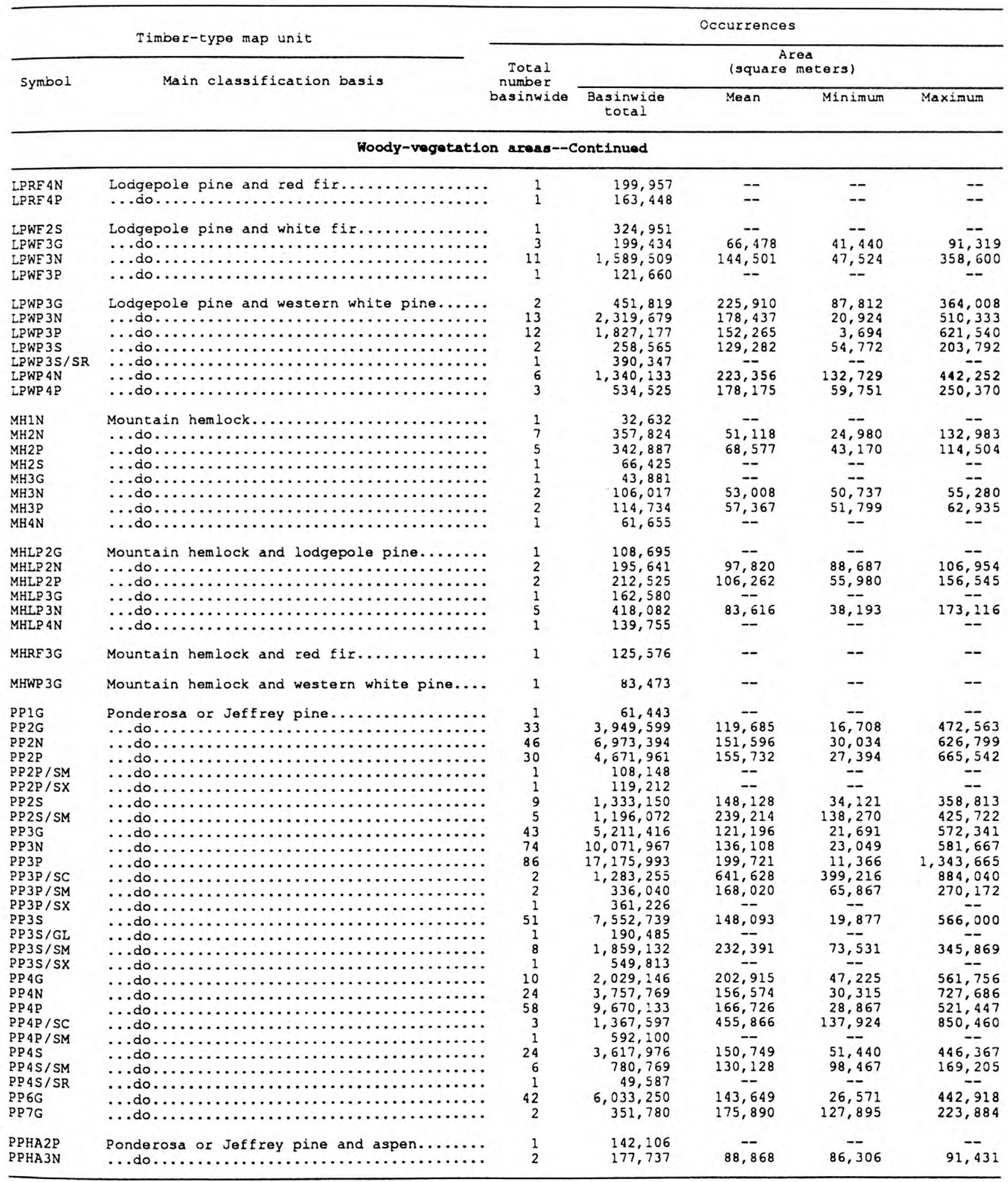


Table 19. Summary documentation for spatial data base TIMBER_TYPE in Tanoe Environmental Geographic Information System-Continued

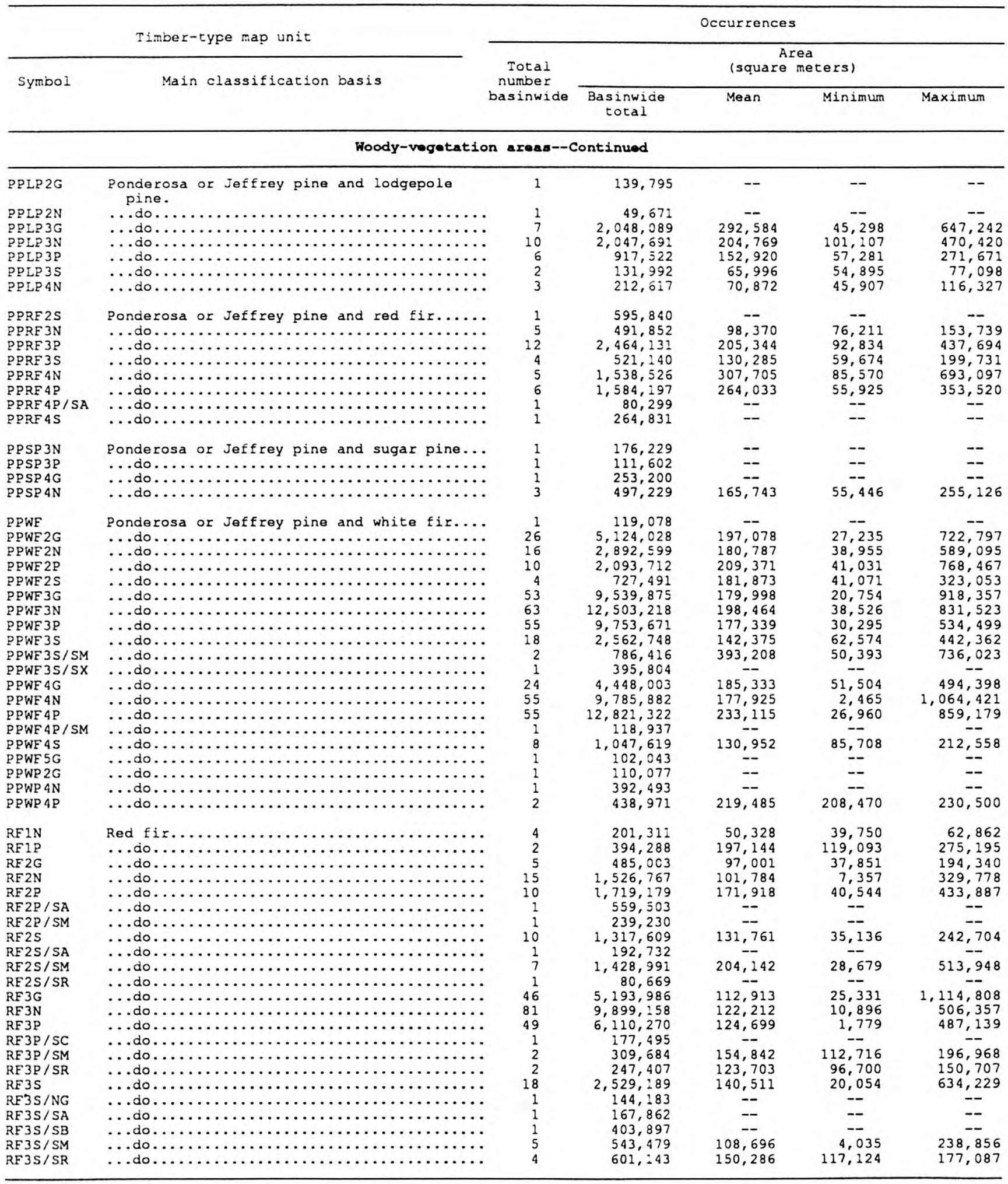




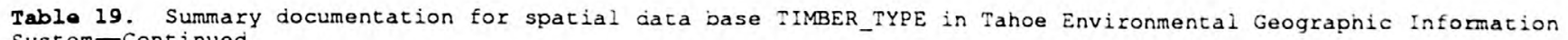
System-Continued

\begin{tabular}{|c|c|c|c|c|c|c|}
\hline \multicolumn{2}{|r|}{ Timber-type map unit } & \multicolumn{5}{|c|}{ Occurrences } \\
\hline \multirow{2}{*}{ Symbol } & \multirow{2}{*}{ Main classification basis } & \multirow{2}{*}{$\begin{array}{c}\text { Total } \\
\text { number } \\
\text { basinwide }\end{array}$} & \multicolumn{4}{|c|}{ 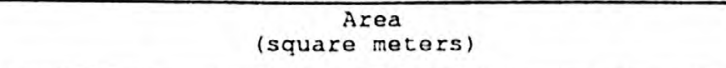 } \\
\hline & & & $\begin{array}{c}\text { Basinwiae } \\
\text { total }\end{array}$ & Mean & Minimum & Maximum \\
\hline \multicolumn{7}{|c|}{ Woody-vegetation areas--Continued } \\
\hline $\begin{array}{l}\text { RF } 4 \text { G } \\
\text { RF } 4 N \\
\text { RF } 4 \text { P } \\
\text { RF } 4 \text { P / SR } \\
\text { RE } 4 \text { S } \\
\text { RF } 4 \text { S / SR } \\
\text { RF } 6 \text { G }\end{array}$ & 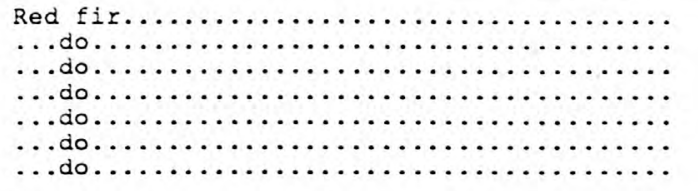 & $\begin{array}{r}27 \\
42 \\
8 \\
1 \\
7 \\
1 \\
1\end{array}$ & $\begin{array}{r}5,802,462 \\
7,326,148 \\
1,376,133 \\
69,628 \\
1,386,032 \\
114,862 \\
51,850\end{array}$ & $\begin{array}{l}214,906 \\
174,432 \\
172,017 \\
198,005 \\
--\end{array}$ & $\begin{array}{l}29,653 \\
28,214 \\
71,563 \\
25,844 \\
--\end{array}$ & $\begin{array}{l}718,922 \\
823,668 \\
357,559 \\
-- \\
543,092 \\
- \\
-\end{array}$ \\
\hline $\begin{array}{l}\text { RFLP 2N } \\
\text { RFLP 2P } \\
\text { RFLP 2S } \\
\text { RFLP 3G } \\
\text { RFLP 3N } \\
\text { RELP 3P } \\
\text { RELP } 4 \text { G } \\
\text { RFLP 4N } \\
\text { RFLP } 4 \text { P } \\
\text { RFLP } 4 \text { S/SR }\end{array}$ & 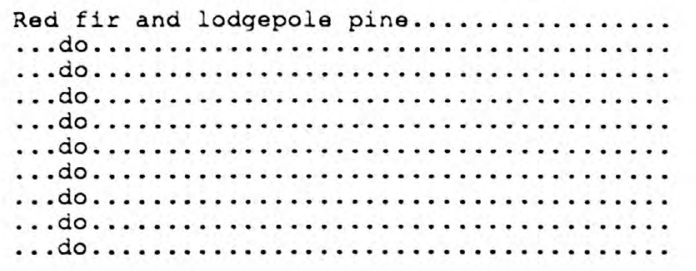 & $\begin{array}{r}1 \\
3 \\
1 \\
10 \\
28 \\
16 \\
1 \\
7 \\
2 \\
1\end{array}$ & $\begin{array}{r}108,139 \\
703,816 \\
45,129 \\
1,738,006 \\
4,155,485 \\
2,434,206 \\
146,049 \\
1,271,752 \\
611,412 \\
115,633\end{array}$ & $\begin{array}{c}-- \\
234,605 \\
-- \\
173,801 \\
148,410 \\
152,138 \\
-- \\
181,679 \\
305,706 \\
\end{array}$ & $\begin{array}{c}-- \\
65,503 \\
-- \\
73,697 \\
49,197 \\
3,622 \\
-- \\
8 !, 428 \\
269,196 \\
\end{array}$ & $\begin{array}{c}-- \\
401,418 \\
359,292 \\
301,305 \\
374,412 \\
-- \\
385,019 \\
342,216\end{array}$ \\
\hline $\begin{array}{l}\text { RFMH 2N } \\
\text { RFMH2P } \\
\text { REMH 2P/SR } \\
\text { RFMH 3G } \\
\text { REMH 3N } \\
\text { REMH 3P } \\
\text { RFMH 4N }\end{array}$ & 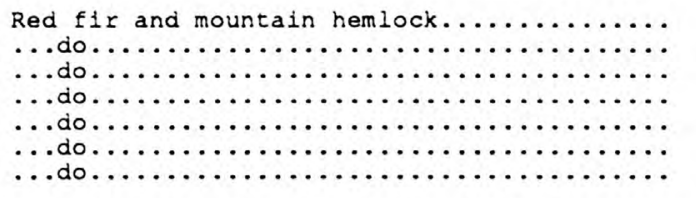 & $\begin{array}{l}1 \\
1 \\
1 \\
3 \\
6 \\
2 \\
1\end{array}$ & $\begin{array}{r}97,783 \\
87,033 \\
86,665 \\
582,576 \\
560,376 \\
171,989 \\
119,222\end{array}$ & $\begin{array}{l}-- \\
194,192 \\
93,396 \\
85,995\end{array}$ & $\begin{array}{c}-- \\
-- \\
-- \\
71,398 \\
42,700 \\
77,620 \\
--\end{array}$ & $\begin{array}{c}-- \\
-- \\
365,347 \\
137.639 \\
94, .369 \\
--\end{array}$ \\
\hline 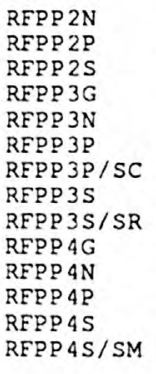 & 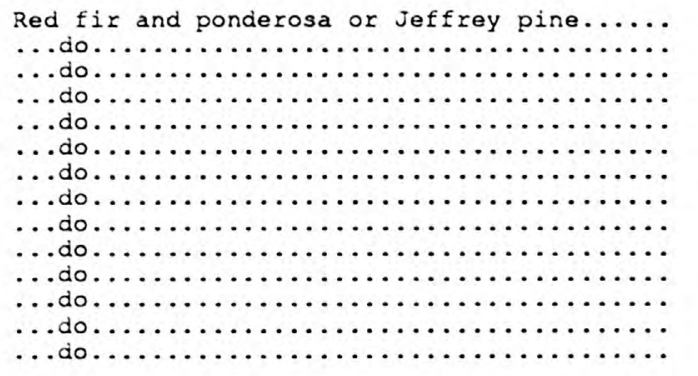 & $\begin{array}{r}1 \\
3 \\
1 \\
4 \\
14 \\
14 \\
1 \\
5 \\
2 \\
1 \\
17 \\
10 \\
4 \\
2\end{array}$ & $\begin{array}{r}174,360 \\
186,464 \\
201,599 \\
832,264 \\
2,352,496 \\
1,914,628 \\
132,391 \\
930,098 \\
487,783 \\
609,645 \\
2,896,422 \\
2,122,773 \\
601,662 \\
345,304\end{array}$ & $\begin{array}{c}62,155 \\
-- \\
208,066 \\
168,035 \\
136,759 \\
-- \\
186,020 \\
243,892 \\
-- \\
170,378 \\
212,277 \\
150,415 \\
172,652\end{array}$ & $\begin{array}{c}58,314 \\
-- \\
62,573 \\
63,466 \\
44,959 \\
-- \\
82,095 \\
176,115 \\
-- \\
39,294 \\
16,591 \\
86,214 \\
19,095\end{array}$ & $\begin{array}{c}-- \\
68,934 \\
-- \\
460,963 \\
420,577 \\
297,633 \\
-- \\
263,582 \\
311,668 \\
-- \\
349,346 \\
558,667 \\
236,466 \\
326,209\end{array}$ \\
\hline $\begin{array}{l}\text { REWE 2G } \\
\text { REWE 2P } \\
\text { REWE 2S } \\
\text { RFWE 3G } \\
\text { RFWF 3N } \\
\text { RFWE 3P } \\
\text { REWE 3S } \\
\text { REWE 4G } \\
\text { REWE 4N } \\
\text { REWF 4P }\end{array}$ & 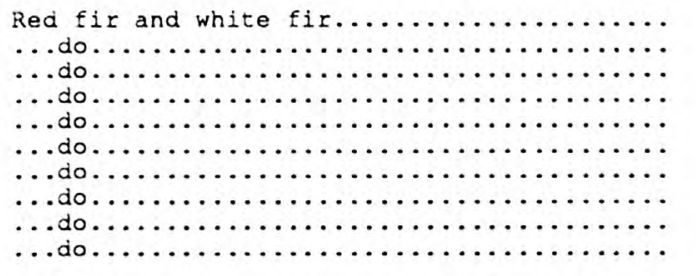 & $\begin{array}{r}3 \\
1 \\
1 \\
5 \\
12 \\
9 \\
2 \\
1 \\
5 \\
4\end{array}$ & $\begin{array}{r}596,835 \\
234,394 \\
208,860 \\
722,089 \\
2,782,321 \\
2,683,047 \\
208,227 \\
124,305 \\
1,209,264 \\
1,093,831\end{array}$ & $\begin{array}{l}198,945 \\
144,418 \\
231,860 \\
298,116 \\
104,114 \\
241,853 \\
273,458\end{array}$ & $\begin{array}{c}183,487 \\
-- \\
-- \\
82,257 \\
74,983 \\
20,641 \\
103,136 \\
-- \\
121,614 \\
208,696\end{array}$ & $\begin{array}{c}222,421 \\
-- \\
249,213 \\
934,404 \\
609,841 \\
105,091 \\
-- \\
426,182 \\
352,542\end{array}$ \\
\hline $\begin{array}{l}\text { RFWP } \\
\text { RFWP 2P } \\
\text { REWP 3G } \\
\text { RFWP 3N } \\
\text { RFWP 3P } \\
\text { RFWP 4G } \\
\text { REWP 4N } \\
\text { RFWP 4P } \\
\text { RFWP 4S }\end{array}$ & 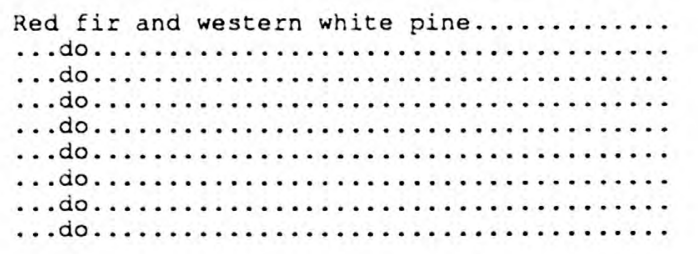 & $\begin{array}{r}1 \\
1 \\
3 \\
7 \\
7 \\
6 \\
12 \\
5 \\
2\end{array}$ & $\begin{array}{r}248,798 \\
116,448 \\
672,327 \\
1,269,490 \\
948,787 \\
619,440 \\
2,871,781 \\
790,184 \\
188,636\end{array}$ & $\begin{array}{l}-- \\
224,109 \\
181,356 \\
135,541 \\
103,240 \\
239,315 \\
158,037 \\
94,318\end{array}$ & $\begin{array}{c}-- \\
-- \\
37,972 \\
35,189 \\
63,766 \\
25,563 \\
57,195 \\
121,860 \\
85,758\end{array}$ & $\begin{array}{c}-- \\
-- \\
581,501 \\
568,800 \\
232,930 \\
182,003 \\
623,984 \\
193,458 \\
102,878\end{array}$ \\
\hline SP $4 \mathrm{~S}$ & sugar pine $\ldots \ldots \ldots \ldots \ldots \ldots \ldots \ldots$ & 1 & 53,824 & -- & -- & -- \\
\hline SPPP 4P & Sugar pine and ponderosa or Jeffrey uine... & 1 & 365,772 & -- & -- & -- \\
\hline
\end{tabular}


Table 19. Summary documentation for spatial data base TIMBER_TYPE in Tahoe Environmental Geographic Information System-Continued

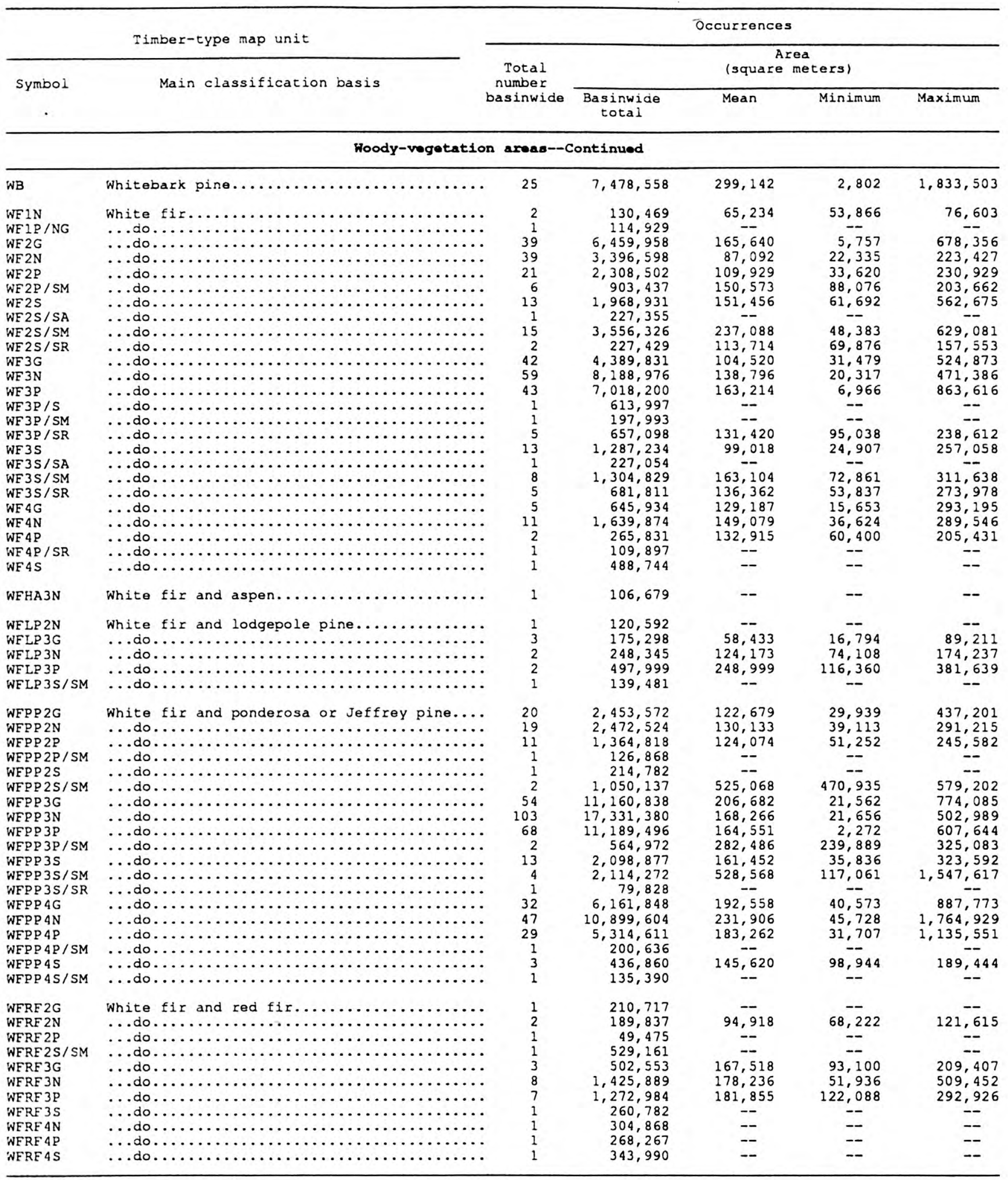


Table 19. Summary documentation for spatial data base IIMBER_TYPE in Tahoe Environmental Geographic Inforation System-Continued

\begin{tabular}{|c|c|c|c|c|c|c|}
\hline \multicolumn{2}{|r|}{ Timber-type map unit } & \multicolumn{5}{|c|}{ Occurrences } \\
\hline \multirow{2}{*}{ Symbol } & \multirow{2}{*}{ Main classification basis } & \multirow{2}{*}{$\begin{array}{l}\text { Total } \\
\text { number } \\
\text { sasinwide }\end{array}$} & \multicolumn{4}{|c|}{$\begin{array}{c}\text { Area } \\
\text { (square meters) }\end{array}$} \\
\hline & & & $\begin{array}{l}\text { Basinwide } \\
\text { total }\end{array}$ & Mean & Minimum & Maximum \\
\hline \multicolumn{7}{|c|}{ Woody-vegetat1on areas--Continued } \\
\hline WFWP 4P & White fir and western white pine......... & 1 & 572,744 & -- & -- & -- \\
\hline $\begin{array}{l}\text { WP2G } \\
\text { WP 2P } \\
\text { WP 3G } \\
\text { WP 3N } \\
\text { WP 3P } \\
\text { WP 3P / SM } \\
\text { WP 3S } \\
\text { WP 4N } \\
\text { WP 4P } \\
\text { WP 4S } \\
\text { WP 6G }\end{array}$ & 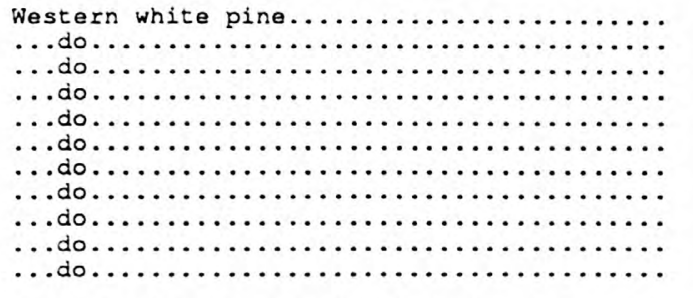 & $\begin{array}{l}1 \\
1 \\
1 \\
2 \\
2 \\
1 \\
4 \\
1 \\
1 \\
1 \\
1\end{array}$ & $\begin{array}{r}145,381 \\
29,010 \\
29,483 \\
175,145 \\
353,622 \\
219,999 \\
305,432 \\
127,202 \\
198,039 \\
109,616 \\
112,464\end{array}$ & $\begin{array}{c}-- \\
-- \\
-- \\
87,573 \\
176,811 \\
-\bar{y} \\
76,358 \\
-- \\
-- \\
-- \\
--\end{array}$ & $\begin{array}{c}-- \\
-- \\
-- \\
63,677 \\
105,690 \\
-- \\
32,624 \\
-- \\
-- \\
-- \\
--\end{array}$ & $\begin{array}{c}-- \\
-- \\
-- \\
211,468 \\
247,932 \\
-- \\
109,563 \\
-- \\
-- \\
-- \\
--\end{array}$ \\
\hline $\begin{array}{l}\text { WPLP } 3 \mathrm{~N} \\
\text { WPLP 4N }\end{array}$ & $\begin{array}{l}\text { Western white pine and lodgepole pine...... } \\
\ldots \ldots \text { do } \ldots \ldots \ldots \ldots \ldots \ldots \ldots \ldots \ldots \ldots \ldots \ldots\end{array}$ & $\begin{array}{l}1 \\
1\end{array}$ & $\begin{array}{r}584,011 \\
69,367\end{array}$ & -- & $-\overline{-}$ & -- \\
\hline WPMH $3 N$ & Western white pine and mountain hemlock.... & 1 & 80,618 & -- & - & -- \\
\hline WPPP 2G & $\begin{array}{l}\text { Western white pine and ponderosa or Jeffrey } \\
\text { pine. }\end{array}$ & 1 & 66,447 & -- & -- & -- \\
\hline $\begin{array}{l}\text { WPPP } 3 G \\
\text { WPPP 3N } \\
\text { WPPP } 3 P\end{array}$ & 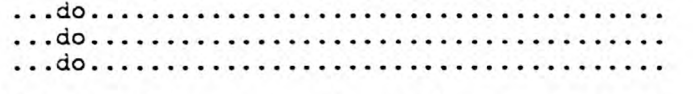 & $\begin{array}{l}1 \\
2 \\
1\end{array}$ & $\begin{array}{r}197,861 \\
893,285 \\
56,939\end{array}$ & $446, \overline{--}$ & $292, \overline{4} 00$ & $600, \overline{885}$ \\
\hline $\begin{array}{l}\text { WPRF 3G } \\
\text { WPRE 3N } \\
\text { WPRE 3P } \\
\text { WPRE 3S } \\
\text { WPRF 4N } \\
\text { WPRE 4P } \\
\text { WPRF } 4 S\end{array}$ & 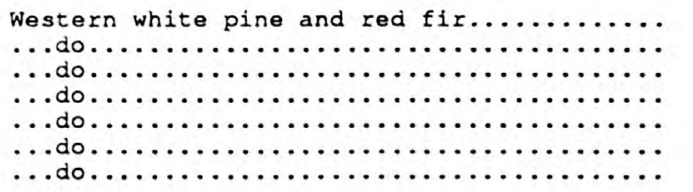 & $\begin{array}{l}1 \\
3 \\
1 \\
1 \\
4 \\
7 \\
1\end{array}$ & $\begin{array}{r}277,859 \\
621,579 \\
54,512 \\
129,521 \\
1,113,905 \\
572,405 \\
60,829\end{array}$ & $\begin{array}{l}207, \overline{193} \\
278, \overline{476} \\
81,772 \\
--\end{array}$ & $\begin{array}{l}53,479 \\
-- \\
77,358 \\
20,310\end{array}$ & $\begin{array}{c}-- \\
439,919 \\
- \\
- \\
620,841 \\
142,280 \\
=\end{array}$ \\
\hline
\end{tabular}

Nonwoody- and shrub-vegetation areas

\begin{tabular}{|c|c|c|c|c|c|c|}
\hline $\mathrm{GH}$ & 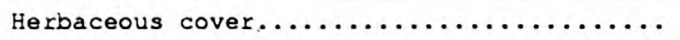 & 3 & 356,377 & 118,792 & 47,091 & 211,620 \\
\hline GL & 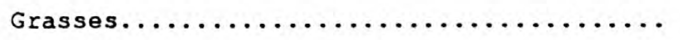 & 110 & $23,213,174$ & 211,029 & 9,214 & $3,679,131$ \\
\hline NG & 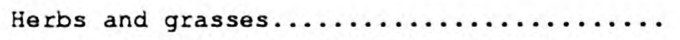 & 1 & 77,243 & -- & -- & -- \\
\hline SA & 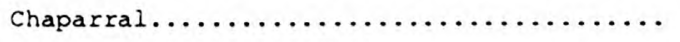 & 12 & $1,719,477$ & 143,290 & 16,536 & 832,151 \\
\hline SB & 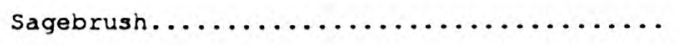 & 22 & $9,286,759$ & 422,125 & 12,088 & $2,882,759$ \\
\hline SC & Shrub (chinquapin) $\ldots \ldots \ldots \ldots \ldots \ldots$ & 11 & $1,806,127$ & 164,193 & 21,481 & 884,134 \\
\hline SM & $\begin{array}{l}\text { Montane (buckbrush, chokecherry, white- } \\
\text { thorn. }\end{array}$ & 129 & $32,445,302$ & 251,514 & 1,237 & $1,943,975$ \\
\hline SR & 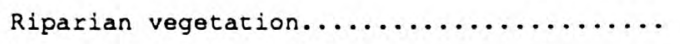 & 118 & $11,232,966$ & 95,195 & 9,900 & 532,268 \\
\hline sx & 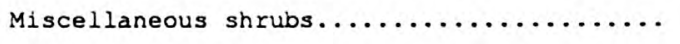 & 3 & 287,217 & 95,739 & 66,887 & 147,927 \\
\hline \multicolumn{7}{|c|}{ Nonvegetated or other areas } \\
\hline ISLA & 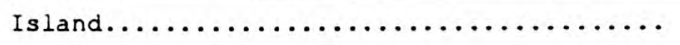 & 37 & 44,283 & 1,197 & 117 & 9,589 \\
\hline NB & 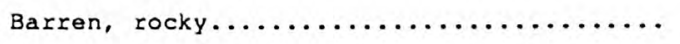 & 145 & $72,851,171$ & 502,422 & 14,322 & $33,600,046$ \\
\hline ND & 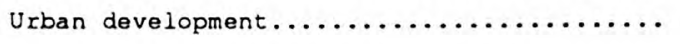 & 62 & $97,910,217$ & $1,579,197$ & 8,034 & $24,420,156$ \\
\hline NM & 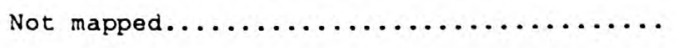 & 17 & $1,070,722$ & 62,984 & 2,919 & 572,481 \\
\hline WBDY & 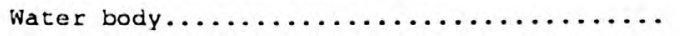 & 381 & $512,924,794$ & $1,346,253$ & 145 & $498,098,470$ \\
\hline
\end{tabular}


Table 20. Detalled documentation for Tahoe

(Coverages listed in alphabetical order by coverage name. For more Information on date of data source, see table 5 . Dem, ELAS, National Aeronautics and Space Adminlstration's Science and Technology Laboratory Applications Software; GIS, RMS, root-mean-square error, in digitizer Inches; TEGIS, Tahoe Environmental Geographic Information System; TRPA, Service; --

Data source

Descripeion of coverage

\begin{tabular}{|c|c|c|c|c|}
\hline Agency and (or) derlvation & Scale & Date & $\stackrel{\text { Map }}{\text { projection }}$ & $\begin{array}{l}\text { Media type } \\
\text { and condition, } \\
\text { if applicable }\end{array}$ \\
\hline
\end{tabular}

Digitizing

met hod

TRGIS coverage

\begin{tabular}{|c|c|c|c|c|c|c|}
\hline $\begin{array}{l}\text { Line coverage of laxe } \\
\text { Tahoe basin boundary. }\end{array}$ & $\begin{array}{l}\text { USGS; basin boundary delin- } \\
\text { eated on topographic maps. }\end{array}$ & $1: 24,000$ & 1989 & Polyconic & $\begin{array}{l}\text { Mylar (excel- } \\
\text { lent condi- } \\
\text { tlon). }\end{array}$ & $\begin{array}{l}\text { Thematic lines were } \\
\text { digltized manually; } \\
\text { feature labels were } \\
\text { assigned interac- } \\
\text { tively by using } \\
\text { ARC/INFO software. }\end{array}$ \\
\hline
\end{tabular}

TRGIS coverage

ine coverage of outer boundary of Lake Tahoe basin and administrative boundary of TRPA. differs from Lake Tahoe basin boundary in vicinity of Tahoe City. This coverage was used as outer Ilmit for digitizlng natural-resources

layers for TEGIS project. outer-boundary layer

\begin{tabular}{|c|c|c|c|c|c|}
\hline $\begin{array}{l}\text { USGS; basin boundary deline- } \\
\text { ated on topographic maps; } \\
\text { TRPA administrative bound- } \\
\text { ary added on basis of con- } \\
\text { gressionally legislated } \\
\text { description of TRPA bound- } \\
\text { ary (U.S. Publlc Law } 96- \\
551 \text { ) and by using TEGIS } \\
\text { coverage PLSS. }\end{array}$ & $1: 24,000$ & 1989 & Polyconic & $\begin{array}{l}\text { Mylar lexcel- } \\
\text { lent cond1- } \\
\text { tlon) for Lake } \\
\text { Tahoe basin } \\
\text { and Public } \\
\text { Land Survey } \\
\text { System DLG } \\
\text { flles for TRPA } \\
\text { boundary. }\end{array}$ & $\begin{array}{l}\text { Thematic lines were } \\
\text { digitized manualiy; } \\
\text { feacure labels were } \\
\text { asslgned interac- } \\
\text { tively by using } \\
\text { ARC/INEO software. }\end{array}$ \\
\hline
\end{tabular}

TRGIS coverage

Llne coverage of TRPA administrative boundary. whlch corresponds to whlch corresponds to ary with two exceptions: Administrative boundary (1) extends beyond natural-basin bouncary in vicinity of Tahoe City and (2) colncides with and (2) colncldes with in southeastern part of basin (and thereby excludes Alpine County).
Thematic lines were dlgltized manualiy or were derived from DLG Public Land Survey System files; feature labels were assigned interactively by using ARC/INFO software.

\begin{tabular}{|c|c|c|c|c|c|c|}
\hline & & & & & & TEGIS coverage \\
\hline $\begin{array}{l}\text { Line coverage of hydro- } \\
\text { graphic channels. }\end{array}$ & $\begin{array}{l}\text { USGS; derived from DLG } \\
\text { hydrography flles. }\end{array}$ & $1: 24,000$ & $1969-82$ & Polycontc & Digital & $\begin{array}{l}\text { Standard methods for } \\
\text { DLG flles. }\end{array}$ \\
\hline Do. & do. & do. & do. & do. & do. & do. \\
\hline Do. & do. & do. & do. & do. & do. & do. \\
\hline Do. & do. & do. & do. & do. & do. & do. \\
\hline Do. & do. & do. & do. & do. & do. & do. \\
\hline Do. & do. & do. & do. & do. & do. & do. \\
\hline Do. & do. & do. & do. & do. & do. & do. \\
\hline Do. & do. & do. & do. & do. & do. & do. \\
\hline
\end{tabular}


Environmental Geographic information system coverages

U.S. Geological Survey's Digital Elevation Model; DLG, U.S. Geological Survey's Digital Line Graph; do. or Do., ditto; geographlc information system; NASA, National Aeronautics and Space Administration; Res, resolution, 1n meters; Tahoe Regional Planning Agency; USFS, U.S. Forest Service; USGS, U.S. Geological Survey; SCS, U.S. Soil Conservation not applicablel

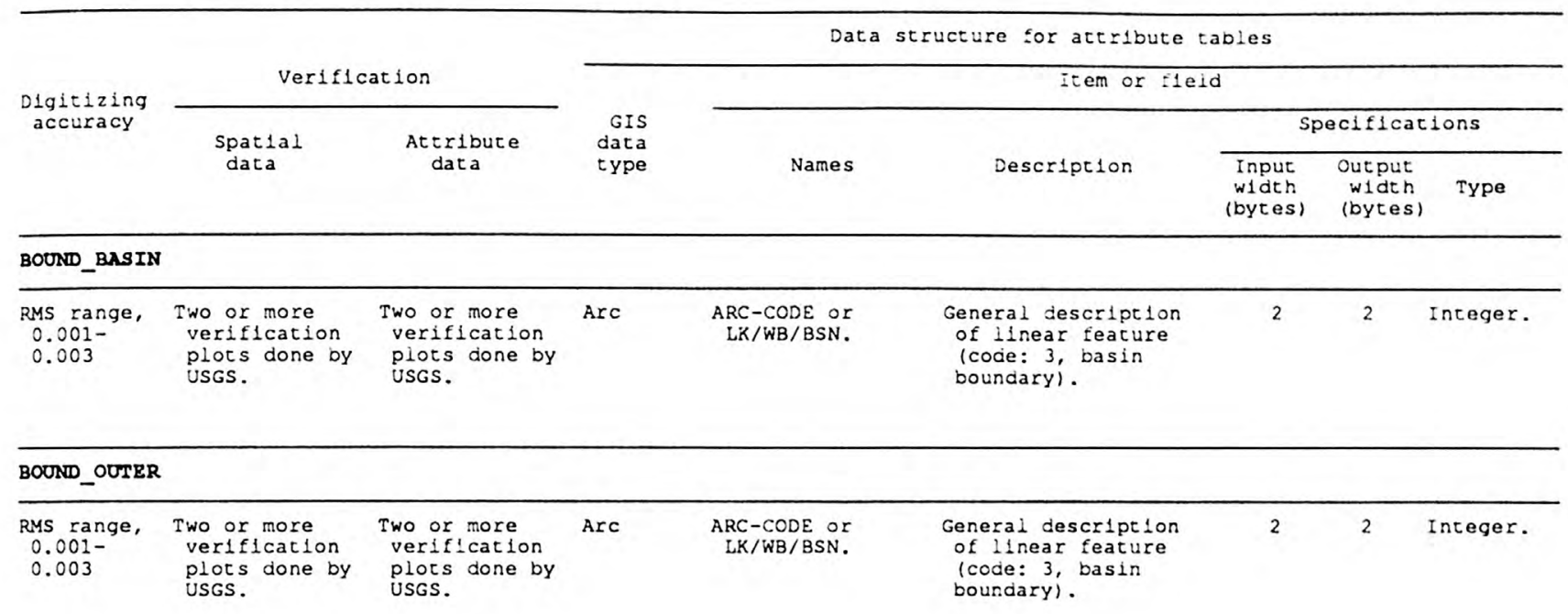

\begin{tabular}{|c|c|c|c|c|c|c|c|c|}
\hline \multicolumn{9}{|l|}{ BOUND_TRPA } \\
\hline $\begin{array}{l}\text { RMS range, } \\
0.001- \\
0.003\end{array}$ & $\begin{array}{l}\text { Two or more } \\
\text { verification } \\
\text { plots done by } \\
\text { USGS. }\end{array}$ & $\begin{array}{l}\text { Two or more } \\
\text { veriflcation } \\
\text { plots done by } \\
\text { USGS. }\end{array}$ & Arc & $\begin{array}{c}\text { ARC-CODE or } \\
\text { LK/WB/BSN. }\end{array}$ & $\begin{array}{l}\text { General description } \\
\text { of linear feature } \\
\text { (code: 3, basin } \\
\text { boundary). }\end{array}$ & 2 & 2 & Integer. \\
\hline
\end{tabular}

\begin{tabular}{|c|c|c|c|c|c|c|c|c|}
\hline \multicolumn{9}{|l|}{ CHANLNRI } \\
\hline $\begin{array}{l}\text { Standards } \\
\text { for DLG } \\
\text { flles. }\end{array}$ & $\begin{array}{l}\text { According to } \\
\text { dlgitizing } \\
\text { standards for } \\
\text { DLG files. }\end{array}$ & $\begin{array}{l}\text { According to } \\
\text { dlgitizing } \\
\text { standards for } \\
\text { DLG flies. }\end{array}$ & Arc & MAJORI & DLG code & 6 & 6 & Integer. \\
\hline do. & do. & do. & do. & MINOR1 & do. & 6 & 6 & Do. \\
\hline do. & do. & do. & do. & MAJOR2 & do. & 6 & 6 & Do. \\
\hline do. & do. & do. & do. & MINOR2 & do. & 6 & 6 & Do. \\
\hline do. & do. & do. & do. & MAJOR3 & do. & 6 & 6 & Do. \\
\hline do. & do. & do. & do. & MINOR3 & do. & 6 & 6 & Do. \\
\hline do. & do. & do. & do. & MAJOR4 & do. & 6 & 6 & Do. \\
\hline do. & do. & do. & do. & MINOR4 & do. & 6 & 6 & Do. \\
\hline
\end{tabular}


Tabl. 20. Detailed documentation for Tahoe Environmental

\begin{tabular}{|c|c|c|c|c|c|c|}
\hline \multirow{2}{*}{ Description of coverage } & \multicolumn{5}{|c|}{ Data source } & \multirow{2}{*}{$\begin{array}{l}\text { D1gitizing } \\
\text { method }\end{array}$} \\
\hline & Agency and $(o r)$ derivation & Scale & Date & $\begin{array}{c}\text { Map } \\
\text { projecrion }\end{array}$ & $\begin{array}{l}\text { Media type } \\
\text { and condition, } \\
\text { If applicable }\end{array}$ & \\
\hline & & & & & & TRGIS coverage \\
\hline $\begin{array}{l}\text { Ine coverage of hyaro- } \\
\text { graphlc channels. }\end{array}$ & $\begin{array}{l}\text { USGS; derived from DLG } \\
\text { hydrography files. }\end{array}$ & $1: 24,000$ & $1969-82$ & Polyconic & Dlgital & $\begin{array}{l}\text { Standard methods for } \\
\text { DLG flles. }\end{array}$ \\
\hline Do. & do. & do. & do. & do. & do. & do. \\
\hline \multirow[t]{2}{*}{ Do. } & do. & do. & do. & do. & do. & do. \\
\hline & \multicolumn{6}{|r|}{ TrGIS coverage } \\
\hline \multirow{2}{*}{$\begin{array}{l}\text { Llne coverage of county } \\
\text { boundarles (cllpped at } \\
\text { outer Lake Tahoe basin } \\
\text { boundary, as defined } \\
\text { by TEGIS coverage } \\
\text { BOUND_OUTER). }\end{array}$} & $\begin{array}{l}\text { USGS; derived from DLG } \\
\text { boundarles flles. }\end{array}$ & $1: 24,000$ & $1969-82$ & Polyconic & Digical & $\begin{array}{l}\text { Standard methods for } \\
\text { DLG flles. }\end{array}$ \\
\hline & \multicolumn{6}{|r|}{ TEGIS coverage } \\
\hline $\begin{array}{l}\text { Polygon coverage of } \\
\text { geologic units. }\end{array}$ & $\begin{array}{l}\text { Dlgitlzed from composite of } \\
\text { eight geologic and related } \\
\text { maps (see table 1, fig. 4). }\end{array}$ & $\begin{array}{l}1: 125,000 \\
\text { and } \\
1: 24,000\end{array}$ & $1964-85$ & Polyconic & $\begin{array}{l}\text { Paper composite } \\
\text { (good condi- } \\
\text { tlon) or mylar } \\
\text { separates } \\
\text { (excellent } \\
\text { condltion). }\end{array}$ & $\begin{array}{l}\text { Thematic lines were } \\
\text { digitlzed by using } \\
\text { electronic scanner } \\
\text { except for manual } \\
\text { digltizing of TRPA } \\
\text { map (table 1): fea- } \\
\text { ture labels were } \\
\text { assigned interac- } \\
\text { tively by using } \\
\text { ARC/INFO software. }\end{array}$ \\
\hline Do. & do. & do. & do. & do. & do. & do. \\
\hline Do. & do. & do. & do. & do. & do. & do. \\
\hline \multirow[t]{2}{*}{ Do. } & do. & do. & do. & do. & do. & do. \\
\hline & \multicolumn{6}{|r|}{ TEGIS coverage } \\
\hline $\begin{array}{l}\text { Line coverage of geologic } \\
\text { linear features. }\end{array}$ & $\begin{array}{l}\text { Dlgitized from composite of } \\
\text { elght geologic and related } \\
\text { maps (see table 1, fig. 4). }\end{array}$ & $\begin{array}{l}1: 125,000 \\
\text { and } \\
1: 24,000\end{array}$ & $1964-85$ & Polyconic & $\begin{array}{l}\text { Paper composite } \\
\text { (good condi- } \\
\text { tion) or mylar } \\
\text { separates } \\
\text { (excellent } \\
\text { condltion). }\end{array}$ & $\begin{array}{l}\text { Thematic ilnes were } \\
\text { digitized by using } \\
\text { electronic scanner } \\
\text { except for manual } \\
\text { digitizing of TRPA } \\
\text { map (table l); fea- } \\
\text { ture labels were } \\
\text { assigned interac- } \\
\text { tively by using } \\
\text { ARC/INFO software. }\end{array}$ \\
\hline
\end{tabular}




\begin{tabular}{|c|c|c|c|c|c|c|c|c|}
\hline \multirow{4}{*}{$\begin{array}{l}\text { Digitizing } \\
\text { accuracy }\end{array}$} & \multirow{2}{*}{\multicolumn{2}{|c|}{ Verification }} & \multicolumn{6}{|c|}{ Data structure for attrlbute tables } \\
\hline & & & \multirow{3}{*}{$\begin{array}{l}\text { GIS } \\
\text { data } \\
\text { type }\end{array}$} & \multicolumn{5}{|c|}{ Item or fleld } \\
\hline & \multirow{2}{*}{$\begin{array}{l}\text { Spatial } \\
\text { data }\end{array}$} & \multirow{2}{*}{$\begin{array}{l}\text { Actribute } \\
\text { data }\end{array}$} & & \multirow[b]{2}{*}{ Names } & \multirow[b]{2}{*}{ Description } & \multicolumn{3}{|c|}{ Spec1ficarlons } \\
\hline & & & & & & $\begin{array}{l}\text { Input } \\
\text { width } \\
\text { (bytes) }\end{array}$ & $\begin{array}{l}\text { Output } \\
\text { width } \\
\text { (byces) }\end{array}$ & Type \\
\hline \multicolumn{9}{|c|}{ CBANREI--Continued } \\
\hline $\begin{array}{l}\text { Standards } \\
\text { for DLG } \\
\text { flles. }\end{array}$ & $\begin{array}{l}\text { According to } \\
\text { diglizing } \\
\text { standards for } \\
\text { DIG flles. }\end{array}$ & $\begin{array}{l}\text { According to } \\
\text { digitizing } \\
\text { standards for } \\
\text { DLG flies. }\end{array}$ & Arc & $\begin{array}{l}\text { LAKE/CHANNEL Or } \\
\text { ARC-CODE. }\end{array}$ & $\begin{array}{l}\text { General description } \\
\text { of Inear fearure } \\
\text { (codes: 1, connect- } \\
\text { 1ng arc through lake: } \\
2 \text {, channel arc). }\end{array}$ & 1 & 1 & Inceger. \\
\hline do. & do. & do. & do. & $\begin{array}{l}\text { INSIDE/OUTSIDE } \\
\text { or BASIN90. }\end{array}$ & $\begin{array}{l}\text { General description } \\
\text { of linear feature } \\
\text { (codes: 1, arc } \\
\text { lnside basin bound- } \\
\text { ary; arc outside } \\
\text { basin boundary). }\end{array}$ & 1 & 1 & Do. \\
\hline do. & do. & do. & do. & $\begin{array}{l}\text { MAJOR-MINOR_CODE } \\
\text { Or M_CODE. }\end{array}$ & $\begin{array}{l}\text { Comblnat } 1 \text { on of MAJOR } \\
\text { and MINOR codes. }\end{array}$ & 48 & 48 & Character. \\
\hline \multicolumn{9}{|l|}{ coovix } \\
\hline $\begin{array}{l}\text { Standards } \\
\text { for DLG } \\
\text { flles. }\end{array}$ & $\begin{array}{l}\text { According to } \\
\text { digitizing } \\
\text { standards for } \\
\text { DLG files. }\end{array}$ & $\begin{array}{l}\text { According to } \\
\text { digitizing } \\
\text { standards for } \\
\text { DLG flles. }\end{array}$ & Arc & $\begin{array}{l}\text { COUNTY/BUFEER } \\
\text { Or ARC-CODE. }\end{array}$ & $\begin{array}{l}\text { General description } \\
\text { of linear feature } \\
\text { (codes: 1, county } \\
\text { arc; 2, buffer arc). }\end{array}$ & 2 & 2 & Integer. \\
\hline \multicolumn{9}{|l|}{ GrOI_COMP } \\
\hline $\begin{array}{l}\text { RMS range, } \\
0.001 \\
0.005 \\
\text { Res range, } \\
0.459- \\
3.167\end{array}$ & $\begin{array}{l}\text { Two or more } \\
\text { verification } \\
\text { plots, per } \\
\text { copographic } \\
\text { quadrangle } \\
\text { (fig. 4), done } \\
\text { by USGS. }\end{array}$ & $\begin{array}{l}\text { Three or more } \\
\text { veriflcation } \\
\text { plots, per } \\
\text { topographic } \\
\text { quadrangle } \\
\text { (flg. 4), done } \\
\text { by USGS. }\end{array}$ & Arc & $\begin{array}{l}\text { ARC-CODE or } \\
\mathrm{LK} / \mathrm{WB} / \mathrm{BSN}\end{array}$ & $\begin{array}{l}\text { General description } \\
\text { of linear feacure } \\
\text { (codes: 1, Lake Tahoe } \\
\text { boundary; 2, water- } \\
\text { body boundary; } 3, \\
\text { basin boundary; } 8, \\
\text { fault; } 9, \text { geologic } \\
\text { contact; 10, edge of } \\
\text { map quadrangle). }\end{array}$ & 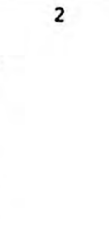 & 2 & Integer. \\
\hline do. & do. & do. & Polygon & $\begin{array}{l}\text { GEOLOGY-UNIT } \\
\text { OF MAP-UNIT. }\end{array}$ & Geologic-unit symbol & 6 & 6 & Character. \\
\hline do. & do. & do. & do. & $\begin{array}{l}\text { QUAD-ABBREV Or } \\
\text { QUAD-NAME. }\end{array}$ & $\begin{array}{l}\text { Abbreviated name for } \\
1: 24,000-s c a l e \text { copo- } \\
\text { graphic quadrangle. }\end{array}$ & 16 & 16 & Character. \\
\hline do. & do. & do. & do. & $\begin{array}{l}\text { WATERBODY Or } \\
\text { WB-CODE. }\end{array}$ & Water-body code & 6 & 6 & Integer. \\
\hline \multicolumn{9}{|c|}{ GROI_CONP_IN } \\
\hline $\begin{array}{l}\text { RMS range, } \\
0.001- \\
0.005 ; \\
\text { Res range, } \\
0.459- \\
3.167\end{array}$ & $\begin{array}{l}\text { Two or more } \\
\text { veriflcation } \\
\text { plots done by } \\
\text { USGs. }\end{array}$ & $\begin{array}{l}\text { Three or more } \\
\text { verification } \\
\text { plots done by } \\
\text { USGS. }\end{array}$ & Arc & $\begin{array}{l}\text { EAU/INTR/CONC } \\
\text { or FAULT-CODE. }\end{array}$ & $\begin{array}{l}\text { General description } \\
\text { of linear feature } \\
\text { (codes: 1, fault; } \\
\text { 2, inferred fault; } \\
\text { 3, concealed fault; } \\
\text { 4, moraine crest; } 5 \text {, } \\
\text { dike; 6, shear zone; } \\
7 \text {, gradational con- } \\
\text { (acc). }\end{array}$ & 1 & 1 & Integer. \\
\hline
\end{tabular}


Table 20. Detailed documentation for Tanoe Enviromental

Data source

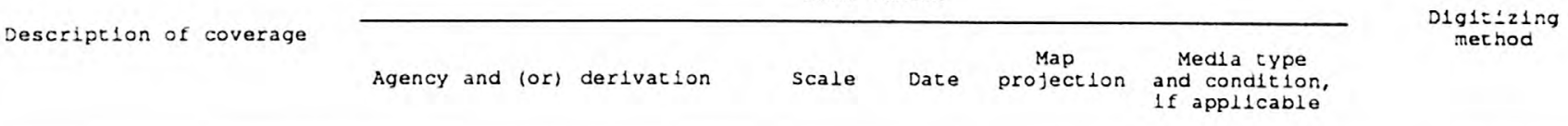

TRGIS coverage

\begin{tabular}{lcc}
\hline $\begin{array}{c}\text { Polygon coverage of } \\
\text { geologic units. }\end{array}$ & $\begin{array}{c}\text { Digitized from TRPA natural- } \\
\text { hazards map (see table } 1) .\end{array}$ & (recom- \\
& & piled at \\
& &
\end{tabular}

Polyconic Mylar lgood condition except for

two warped quadrangles

quadrangscale Emeralo Bay and Kings Beach).
Do.
do.
do.
do.
do.
do.
do.
Do.
do.
do.
do.
do.
do.

.
do.

Thematic lines were digitized manually; castore labels wer tively by using ARC/INFO software.

do.

TrGIs coverage

\begin{tabular}{|c|c|c|c|c|c|}
\hline $\begin{array}{l}\text { Line coverage of geologic } \\
\text { linear features. }\end{array}$ & $\begin{array}{l}\text { D1gitlzed from TRPA natural- } \\
\text { hazards maps (see table } 1 \text { ). }\end{array}$ & $\begin{array}{l}1: 125,0001974 \\
\text { (recom- } \\
\text { piled at } \\
1: 24,000)\end{array}$ & Polyconic & $\begin{array}{l}\text { Mylar (good } \\
\text { condrtion } \\
\text { except for } \\
\text { two warped } \\
\text { quadrangles, } \\
\text { l: } 24,000- \\
\text { scale Emerald } \\
\text { Bay and Klngs } \\
\text { Beach). }\end{array}$ & $\begin{array}{l}\text { Thematic ilnes were } \\
\text { digitized manually: } \\
\text { feature labels were } \\
\text { assigned interac- } \\
\text { tively by using } \\
\text { ARC/INFO software. }\end{array}$ \\
\hline
\end{tabular}

TEGIS coverage

\begin{tabular}{|c|c|c|c|c|c|c|}
\hline $\begin{array}{l}\text { Polygon coverage of } \\
\text { hydrologic basins, coded } \\
\text { according to Jorgensen } \\
\text { and others (1978). }\end{array}$ & $\begin{array}{l}\text { USGS; drainage dlvides delin- } \\
\text { eated on topographlc maps. }\end{array}$ & $1: 24,000$ & 1991 & Polyconic & $\begin{array}{l}\text { Mylar (excel- } \\
\text { lent condi- } \\
\text { tion). }\end{array}$ & $\begin{array}{l}\text { Thematic lines were } \\
\text { dlgitlzed manually; } \\
\text { feature labeis were } \\
\text { assigned interac- } \\
\text { tlvely by using } \\
\text { ARC/INro software. }\end{array}$ \\
\hline
\end{tabular}
Do.
do.
do.
do.
do.
do.
Do.
do.
do.
do.
do.
do.
do.

TEGIS coverage

Polygon coverage of land- USGS; derived from DEM flles $1: 24,000$ aspect zones.

$1955-82$ Polyconlc Digital (mag-
(topo-
graphic
quad-
rangle
publi-
cation
dates).

Do.

do.

do.

do.

do.

do.

Elevation data from DEM files were converted to elevation zones by using NASA' S ELAS rasterformat processing system and to vector-format spatial data bases by using ARC/INFO software; then land-aspect polygons for adjacent map quadrangles were appended successively by using ARC/INFO soft ware.

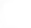

do.

do.

.

do. 


\begin{tabular}{|c|c|c|c|c|c|c|c|c|}
\hline \multirow{4}{*}{$\begin{array}{l}\text { Digltizlng } \\
\text { accuracy }\end{array}$} & \multirow{2}{*}{\multicolumn{2}{|c|}{ Verification }} & \multicolumn{6}{|c|}{ Data structure for attribute tables } \\
\hline & & & \multirow{3}{*}{$\begin{array}{l}\text { GIS } \\
\text { data } \\
\text { type }\end{array}$} & \multicolumn{5}{|c|}{ Item or fleld } \\
\hline & \multirow{2}{*}{$\begin{array}{l}\text { Spatial } \\
\text { data }\end{array}$} & \multirow{2}{*}{$\begin{array}{l}\text { Atcribute } \\
\text { data }\end{array}$} & & \multirow[b]{2}{*}{ Names } & \multirow[b]{2}{*}{ Description } & \multicolumn{3}{|c|}{ Speciflcations } \\
\hline & & & & & & $\begin{array}{l}\text { Input } \\
\text { w1dth } \\
\text { (byces) }\end{array}$ & $\begin{array}{l}\text { Output } \\
\text { wideh } \\
\text { (bytes) }\end{array}$ & Type \\
\hline \multicolumn{9}{|l|}{ GROL_TRPA } \\
\hline $\begin{array}{l}\text { RMS range, } \\
0.001- \\
0.005 ; \\
\text { Res range, } \\
0.459- \\
3.167\end{array}$ & $\begin{array}{l}\text { Four or more } \\
\text { verification } \\
\text { plots done by } \\
\text { USGS. }\end{array}$ & $\begin{array}{l}\text { Three or more } \\
\text { verification } \\
\text { plots done by } \\
\text { USGS. }\end{array}$ & Arc & $\begin{array}{c}\mathrm{ARC}-\mathrm{CODE} \text { or } \\
\mathrm{LK} / \mathrm{WB} / \mathrm{BSN} .\end{array}$ & $\begin{array}{l}\text { Gereral description } \\
\text { of I1near feature } \\
\text { (codes: 1, Lake Tahoe } \\
\text { boundary; 2, water- } \\
\text { body boundary; } 3, \\
\text { basin boundary; } 8, \\
\text { fault; } 9, \text { geologic } \\
\text { contact; } 10 \text {, edge of } \\
\text { map quaarangle). }\end{array}$ & 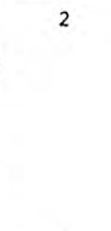 & 2 & Integer. \\
\hline do. & do. & do. & Polygon & $\begin{array}{l}\text { GEOLOGY-UNIT } \\
\text { Or MAP-UNIT. }\end{array}$ & Geoiogic-unit symbol & 6 & 6 & Character. \\
\hline do. & do. & do. & do. & $\begin{array}{l}\text { WATERBODY or } \\
\text { WB-CODE. }\end{array}$ & Water-body code & 6 & 6 & Integer. \\
\hline \multicolumn{9}{|c|}{ GROI_TRPA_IN } \\
\hline $\begin{array}{l}\text { RMS range, } \\
0.001- \\
0.005 ; \\
\text { Res range, } \\
0.459- \\
3.167\end{array}$ & $\begin{array}{l}\text { Eour or more } \\
\text { veriflcation } \\
\text { plots done by } \\
\text { USGS. }\end{array}$ & $\begin{array}{l}\text { Three or more } \\
\text { verification } \\
\text { plots done by } \\
\text { USGS. }\end{array}$ & Arc & $\begin{array}{l}\text { EAU/INTR/CONC } \\
\text { or FAULT-CODE. }\end{array}$ & $\begin{array}{l}\text { General descripeion } \\
\text { of linear feacure } \\
\text { (codes: 1, fault; } \\
\text { 2, inferred fault; } \\
\text { 3, concealed fault; } \\
\text { 4, moralne crest; } 5 \text {, } \\
\text { dike; 6, shear zone; } \\
7 \text {, gradacional con- } \\
\text { (act). }\end{array}$ & 1 & 1 & Integer. \\
\hline \multicolumn{9}{|l|}{ EYD_BASIN } \\
\hline $\begin{array}{l}\text { RMS range, } \\
0.001- \\
0.003 ; \\
\text { Res range, } \\
0.67-1.634\end{array}$ & $\begin{array}{l}\text { Three or more } \\
\text { veriflcation } \\
\text { plots done by } \\
\text { USGS. }\end{array}$ & $\begin{array}{l}\text { Three or more } \\
\text { verification } \\
\text { plots done by } \\
\text { USGS. }\end{array}$ & Arc & $\begin{array}{l}\text { ARC-CODE OI } \\
L K / W B / B S N\end{array}$ & $\begin{array}{l}\text { General description } \\
\text { of linear feature } \\
\text { (codes: 1, Lake Tahoe } \\
\text { boundary; 2, water- } \\
\text { body boundary; 3, } \\
\text { basin boundary). }\end{array}$ & 2 & 2 & Integer. \\
\hline Do. & do. & do. & Polygon & $\begin{array}{l}\text { JORG-1978-BASIN } \\
\text { or JORG-BASINF. }\end{array}$ & $\begin{array}{l}\text { Basin number, accord- } \\
\text { lng to Jorgensen and } \\
\text { others (1978). }\end{array}$ & 5 & 5 & Character. \\
\hline Do. & do. & do. & Polygon & $\begin{array}{l}\text { JORG-BASIN-NAME } \\
\text { or JORG-NAME. }\end{array}$ & $\begin{array}{l}\text { Basin name, according } \\
\text { to jorgensen and } \\
\text { others (1978). }\end{array}$ & 30 & 30 & character. \\
\hline \multicolumn{9}{|l|}{ IAAN_ASPECT } \\
\hline Res, 30 & $\begin{array}{l}\text { One verifica- } \\
\text { tion plot of } \\
\text { vector-format } \\
\text { data done by } \\
\text { using ARC/INFo } \\
\text { software. }\end{array}$ & -- & Arc & $\begin{array}{l}\text { ARC-CODE or } \\
\mathrm{LK} / \mathrm{WB} / \mathrm{BSN} .\end{array}$ & $\begin{array}{l}\text { General description } \\
\text { of linear feature } \\
\text { (codes: 1, Lake Tahoe } \\
\text { boundary; 2, water- } \\
\text { body boundary; 3, } \\
\text { basin boundary). }\end{array}$ & 2 & 2 & Integer. \\
\hline do. & do. & -- & Polygon & $\begin{array}{l}\text { MAP-UNIT or } \\
\text { GRID-CODE. }\end{array}$ & Aspect code & 4 & 5 & Blnary. \\
\hline
\end{tabular}


Data source

Description of coverage

$\begin{array}{lcccc} & \text { Data source } & \text { Digitizir.g } & \begin{array}{c}\text { method } \\ \text { mency and (or) derivation }\end{array} \text { Scale Date projection and condition, } \\ \text { Af applicable }\end{array}$

TRGIS coverage

\begin{tabular}{|c|c|c|c|c|c|c|}
\hline $\begin{array}{l}\text { Polygon coverage of land- } \\
\text { aspect zones. }\end{array}$ & USGS; derived from DEM flles & $1: 24,000$ & $\begin{array}{l}1955-82 \\
\text { (topo- } \\
\text { grapnic } \\
\text { quad- } \\
\text { rangle } \\
\text { publi- } \\
\text { cation } \\
\text { dates). }\end{array}$ & Poiyconic & $\begin{array}{l}\text { Digital (mag- } \\
\text { netic tape). }\end{array}$ & $\begin{array}{l}\text { Elevation data from } \\
\text { DEM files were con- } \\
\text { verted to elevation } \\
\text { zones by using } \\
\text { NASA's ELAS raster- } \\
\text { format processing } \\
\text { system and to vec- } \\
\text { tor-format spatial } \\
\text { data bases by using } \\
\text { ARC/INEO software; } \\
\text { then land-aspect } \\
\text { polygons for adja- } \\
\text { cent map quadran- } \\
\text { gles were appended } \\
\text { successively by } \\
\text { uslng ARC/INFo } \\
\text { software. }\end{array}$ \\
\hline & & & & & & TrGIs coverage \\
\hline $\begin{array}{l}\text { Polygon coverage of } \\
\text { land-capability types. }\end{array}$ & $\begin{array}{l}\text { Data from scs soll-survey } \\
\text { maps modified by using } \\
\text { Bailey (1974) land-capabil- } \\
\text { lty classiflcation. }\end{array}$ & $1: 24,000$ & 1974 & Polyconic & $\begin{array}{l}\text { Paper (folded; } \\
\text { dry lroned } \\
\text { before dig- } \\
\text { 1tizing). }\end{array}$ & $\begin{array}{l}\text { Thematic lines were } \\
\text { digitized by using } \\
\text { electronic scanner; } \\
\text { feature labels were } \\
\text { assigned interac- } \\
\text { tively by using } \\
\text { ARC/INEO software; } \\
\text { soll units were } \\
\text { merged inco land- } \\
\text { capability types } \\
\text { by using ARC/INFo } \\
\text { software. }\end{array}$ \\
\hline
\end{tabular}
Do.
do.
do.
do.
do.
do.
do.

Do.

do.

do.

do.

do.

do.

do.

TEGIS coverage

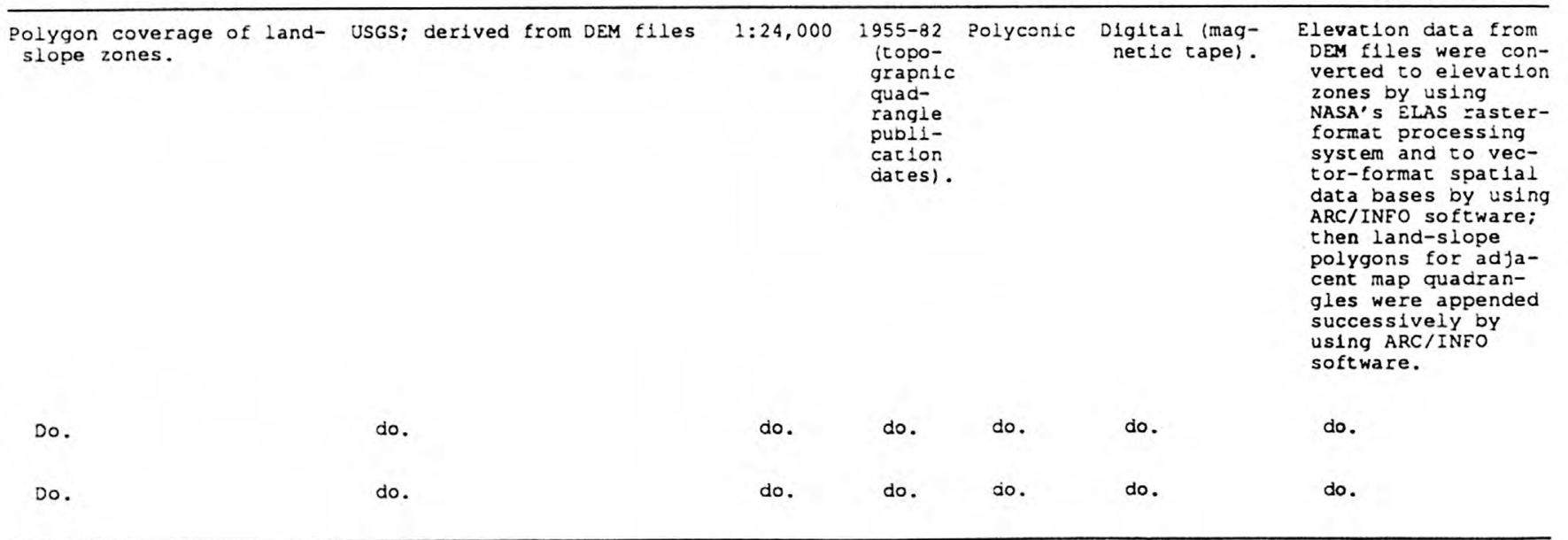




\begin{tabular}{|c|c|c|c|c|c|c|c|c|}
\hline \multirow{4}{*}{$\begin{array}{l}\text { D1gitizing } \\
\text { accuracy }\end{array}$} & \multirow{2}{*}{\multicolumn{2}{|c|}{ Verif1cacion }} & \multicolumn{6}{|c|}{ Data structure for attribuce tables } \\
\hline & & & \multirow{3}{*}{$\begin{array}{r}\text { GIS } \\
\text { data } \\
\text { type }\end{array}$} & \multicolumn{5}{|c|}{ Item or fleld } \\
\hline & \multirow{2}{*}{$\begin{array}{l}\text { Spatial } \\
\text { data }\end{array}$} & \multirow{2}{*}{$\begin{array}{c}\text { Attribute } \\
\text { data }\end{array}$} & & \multirow[b]{2}{*}{ Names } & \multirow[b]{2}{*}{ Description } & \multicolumn{3}{|c|}{ Specificacions } \\
\hline & & & & & & $\begin{array}{l}\text { Input } \\
\text { width } \\
\text { (bytes) }\end{array}$ & $\begin{array}{l}\text { Output } \\
\text { width } \\
\text { (bytes) }\end{array}$ & Type \\
\hline
\end{tabular}

IAND_ASPECT--Continued

\begin{tabular}{|c|c|c|c|c|c|c|c|c|}
\hline Res, 30 & $\begin{array}{l}\text { One verifica- } \\
\text { tion plot of } \\
\text { vector-format } \\
\text { data done by } \\
\text { using ARC/INFo } \\
\text { software. }\end{array}$ & -- & Polygon & $\begin{array}{l}\text { WATERBODY or } \\
\text { WB-CODE. }\end{array}$ & Water-body code & 6 & 6 & Integer. \\
\hline
\end{tabular}

\begin{tabular}{|c|c|c|c|c|c|c|c|c|}
\hline \multicolumn{9}{|l|}{ IAND_CAP } \\
\hline $\begin{array}{l}\text { RMS range, } \\
0.001- \\
0.009 ; \\
\text { Res range, } \\
0.67-5.7\end{array}$ & $\begin{array}{l}\text { Four Ilnework- } \\
\text { verification } \\
\text { plots done by } \\
\text { USGS and two } \\
\text { done by SCS. }\end{array}$ & $\begin{array}{l}\text { Seven verifl- } \\
\text { cation plots } \\
\text { done by USGS } \\
\text { and one done } \\
\text { by USFS and } \\
\text { TRPA. }\end{array}$ & Arc & $\begin{array}{l}\text { ARC-CODE or } \\
\text { LK/WB / BSN. }\end{array}$ & $\begin{array}{l}\text { General description } \\
\text { of linear feacure } \\
\text { (codes: 1, Lake Tahoe } \\
\text { boundary; 2, water- } \\
\text { body boundary; 3, } \\
\text { basin Doundary). }\end{array}$ & 2 & 2 & Integer. \\
\hline
\end{tabular}

\begin{tabular}{|c|c|c|c|c|c|c|c|c|}
\hline do. & do. & do. & Polygon & $\begin{array}{l}\text { LAND-CAPABILITY } \\
\text { or MAP-UNIT. }\end{array}$ & Land-capability code & 2 & 2 & Character. \\
\hline do. & do. & do. & do. & $\begin{array}{l}\text { WATERBODY or } \\
\text { WB-CODE. }\end{array}$ & Water-body code. & 6 & 6 & Integer. \\
\hline \multicolumn{9}{|c|}{ LAND_SLOPE } \\
\hline Res, 30 & $\begin{array}{l}\text { One verlfica- } \\
\text { tion plot of } \\
\text { vector-format } \\
\text { data done by } \\
\text { using ARC/INFO } \\
\text { software. }\end{array}$ & -- & Arc & $\begin{array}{l}\text { ARC-CODE or } \\
\mathrm{LK} / \mathrm{WB} / \mathrm{BSN} .\end{array}$ & $\begin{array}{l}\text { General description } \\
\text { of linear feature } \\
\text { (codes: 1, Lake Tahoe } \\
\text { boundary; 2, water- } \\
\text { body boundary; 3, } \\
\text { basin boundary). }\end{array}$ & 2 & 2 & Integer. \\
\hline
\end{tabular}

\begin{tabular}{llccc} 
do. do. & Polygon & $\begin{array}{c}\text { MAP-UNIT or } \\
\text { GRID-CODE. }\end{array}$ & Slope code \\
do. & do. & do. & $\begin{array}{c}\text { WATERBODY or } \\
\text { WB-CODE. }\end{array}$ & Water-body code \\
\hline
\end{tabular}




\begin{tabular}{|c|c|c|c|c|c|c|}
\hline \multirow{2}{*}{ Description of coverage } & \multicolumn{5}{|c|}{ Data source } & \multirow{2}{*}{$\begin{array}{l}\text { D1gitizing } \\
\text { method }\end{array}$} \\
\hline & Agency and (or) derivation & Scale & Date & $\begin{array}{l}\text { Map } \\
\text { projection }\end{array}$ & $\begin{array}{l}\text { Media type } \\
\text { and condition, } \\
\text { if applicable }\end{array}$ & \\
\hline & & & & & & TRGIS coverage \\
\hline $\begin{array}{l}\text { Point coverage of hydro- } \\
\text { logic-monitoring sites. }\end{array}$ & $\begin{array}{l}\text { Lahontan Water Quality Con- } \\
\text { trol Board; Nevada Division } \\
\text { of Environmental Protect } \\
\text { USFS; USGS; and SCS. Site } \\
\text { locatlons plotted on topo- } \\
\text { grapnlc maps. }\end{array}$ & $1: 24,000$ & 1991 & Polyconic & $\begin{array}{l}\text { Paper (good } \\
\text { condlition). }\end{array}$ & $\begin{array}{l}\text { Thematic lines were } \\
\text { digitized by ising } \\
\text { electronic scanner. } \\
\text { Scanned locattons } \\
\text { for surface-water } \\
\text { sites were trans- } \\
\text { posed to stream- } \\
\text { channel locations } \\
\text { and feature labels } \\
\text { were assigned } \\
\text { lnteractively by } \\
\text { using ARC/INFo } \\
\text { software. }\end{array}$ \\
\hline Do. & do. & do. & do. & do. & do. & do. \\
\hline Do. & do. & do. & do. & do. & do. & do. \\
\hline Do. & do. & do. & do. & do. & do. & do. \\
\hline Do. & do. & do. & do. & do. & do. & do. \\
\hline Do. & do. & do. & do. & do. & do. & do. \\
\hline Do. & do. & do. & do. & do. & do. & do. \\
\hline Do. & do. & do. & do. & do. & do. & do. \\
\hline Do. & do. & do. & do. & do. & do. & do. \\
\hline Do. & do. & do. & do. & do. & do. & do. \\
\hline Do. & do. & do. & do. & do. & do. & do. \\
\hline Do. & do. & do. & do. & do. & do. & do. \\
\hline Do. & do. & do. & do. & do. & do. & do. \\
\hline \multirow[t]{2}{*}{ Do. } & do. & do. & do. & do. & do. & do. \\
\hline & & & & & & TEGIS coverage \\
\hline $\begin{array}{l}\text { Line coverage of publle } \\
\text { Land Survey system } \\
\text { (clipped at outer Lake } \\
\text { Tahoe basin boundary, } \\
\text { as defined by TEGIS } \\
\text { coverage BOUND_OUTER). }\end{array}$ & $\begin{array}{l}\text { USGS; derived from DLG } \\
\text { boundarles flles. }\end{array}$ & $1: 24,000$ & $1969-82$ & Polyconic & Digital & $\begin{array}{l}\text { Standard methods for } \\
\text { DLG f1les. }\end{array}$ \\
\hline
\end{tabular}




\begin{tabular}{|c|c|c|c|c|c|c|c|c|}
\hline \multirow{4}{*}{$\begin{array}{l}\text { Digitizing } \\
\text { accuracy }\end{array}$} & \multirow{2}{*}{\multicolumn{2}{|c|}{ Verification }} & \multicolumn{6}{|c|}{ Data structure for attribute tables } \\
\hline & & & \multirow{3}{*}{$\begin{array}{l}\text { GIS } \\
\text { data } \\
\text { type }\end{array}$} & \multicolumn{5}{|c|}{ Item or fleld } \\
\hline & \multirow{2}{*}{$\begin{array}{l}\text { Spatial } \\
\text { data }\end{array}$} & \multirow{2}{*}{$\begin{array}{l}\text { Attribute } \\
\text { data }\end{array}$} & & \multirow[b]{2}{*}{ Names } & \multirow[b]{2}{*}{ Description } & \multicolumn{3}{|c|}{ Specifications } \\
\hline & & & & & & $\begin{array}{l}\text { Input } \\
\text { width } \\
\text { (byces) }\end{array}$ & $\begin{array}{l}\text { Output } \\
\text { width } \\
\text { (byces) }\end{array}$ & Type \\
\hline \multicolumn{9}{|c|}{ MONITOR_SITL } \\
\hline $\begin{array}{l}\text { RMS range, } \\
0.001- \\
0.003\end{array}$ & $\begin{array}{l}\text { Two veriflca- } \\
\text { tion plots } \\
\text { done by USGS } \\
\text { and checked } \\
\text { by data- } \\
\text { collection } \\
\text { agency. }\end{array}$ & $\begin{array}{l}\text { Two verifica- } \\
\text { tlons done by } \\
\text { daca-collec- } \\
\text { tlon agency. }\end{array}$ & Polnt & $\begin{array}{l}\text { STATION-NUM or } \\
\text { SITE. }\end{array}$ & Station number & 15 & 15 & Character. \\
\hline do. & do. & do. & do. & $\begin{array}{l}\text { AGENCY-ABBREV } \\
\text { or AGENCY. }\end{array}$ & Monitoring agency & 7 & 7 & Character. \\
\hline do. & do. & do. & do. & $\begin{array}{l}\text { STATION-NAME Or } \\
\text { FULL-NAME. }\end{array}$ & Station name & 53 & 53 & Character. \\
\hline do. & do. & do. & do. & $\begin{array}{l}\text { LONGITUDE-DMS } \\
\text { Or LONG. }\end{array}$ & Longltude & 13 & 13 & Character. \\
\hline do. & do. & do. & do. & $\begin{array}{l}\text { LATITUDE-DMS or } \\
\text { LAT. }\end{array}$ & Lat1tude & 11 & 11 & Character. \\
\hline do. & do. & do. & do. & $\begin{array}{l}\text { ALTITUDE-FT or } \\
\text { ALT. }\end{array}$ & Elevation & 7 & 7 & Numeric. \\
\hline do. & do. & do. & do. & $\begin{array}{l}\text { PERIOD-OF-RECORD } \\
\text { Or PERIOD. }\end{array}$ & $\begin{array}{l}\text { Perlod of record, in } \\
\text { years. }\end{array}$ & 23 & 23 & Character. \\
\hline do. & do. & do. & do. & $\begin{array}{l}\text { STATION-TYPE Or } \\
\text { STN-TYPE. }\end{array}$ & Type of station & 8 & 8 & Character. \\
\hline do. & do. & do. & do. & $\begin{array}{l}\text { SAMPLE-PARAMETER } \\
\text { OI SAMP-PARM. }\end{array}$ & Sampling parameters & 23 & 23 & Character. \\
\hline do. & do. & do. & do. & $\begin{array}{l}\text { QUAD-NAME-ABBREV } \\
\text { or QUAD-ABBREV. }\end{array}$ & $\begin{array}{l}\text { Abbreviation of topo- } \\
\text { graphic-quadrangle } \\
\text { name. }\end{array}$ & 3 & 3 & Character. \\
\hline do. & do. & do. & do. & $\begin{array}{l}\text { SW-GAGE-SITE or } \\
\text { GAGE-SITE. }\end{array}$ & $\begin{array}{l}\text { Surface-water gaging } \\
\text { sites. }\end{array}$ & 1 & 1 & Character. \\
\hline do. & do. & do. & do. & $\begin{array}{l}\text { SW-DISCHRG-SITE } \\
\text { or DISC-SITE. }\end{array}$ & $\begin{array}{l}\text { Surface-water discharge } \\
\text { sites. }\end{array}$ & 1 & 1 & Character. \\
\hline do. & do. & do. & do. & $\begin{array}{l}\text { SITE-TO-PLOT or } \\
\text { PLOT-SITE. }\end{array}$ & Long-term site & 1 & 1 & Character. \\
\hline do. & do. & do. & do. & $\begin{array}{l}\text { WATERSHED-SITE } \\
\text { or WSH-SITE. }\end{array}$ & $\begin{array}{l}\text { Watershed-delineation } \\
\text { sites. }\end{array}$ & 1 & 1 & Character. \\
\hline \multicolumn{9}{|l|}{ PIss } \\
\hline $\begin{array}{l}\text { Standards } \\
\text { for DLG } \\
\text { flles. }\end{array}$ & $\begin{array}{l}\text { According to } \\
\text { digitizing } \\
\text { standards for } \\
\text { DLG flies. }\end{array}$ & $\begin{array}{l}\text { According to } \\
\text { digltizing } \\
\text { standards for } \\
\text { DLG files. }\end{array}$ & Arc & $\begin{array}{l}\text { ARC-CODE or } \\
\mathrm{LK} / \mathrm{WB} / \mathrm{BSN} .\end{array}$ & $\begin{array}{l}\text { General descripcion } \\
\text { of linear feature } \\
\text { (codes: 1, Lake Tahoe } \\
\text { boundary; 2, wacer- } \\
\text { body boundary; 3, } \\
\text { basin boundary; } 4, \\
7 \text {, township arc; } 8, \\
\text { range arci 9, arc } \\
\text { added to close poly- } \\
\text { gon (where no pLss } \\
\text { arc exists). }\end{array}$ & 2 & 2 & Integer. \\
\hline
\end{tabular}


Tabl. 20. Detailed documentation for Tahoe Environmental

\begin{tabular}{|c|c|c|c|c|c|c|}
\hline \multirow{2}{*}{ Description of coverage } & \multicolumn{5}{|c|}{ Data source } & \multirow{2}{*}{$\begin{array}{l}\text { Digitizing } \\
\text { method }\end{array}$} \\
\hline & Agency and (or) derivation & Scale & Date & $\begin{array}{c}\text { Map } \\
\text { projection }\end{array}$ & $\begin{array}{l}\text { Medal type } \\
\text { and condition, } \\
\text { If applicable }\end{array}$ & \\
\hline
\end{tabular}

TEGIS coverage

\begin{tabular}{|c|c|c|c|c|c|c|c|}
\hline $\begin{array}{l}\text { Line coverage of Public } \\
\text { Land Survey System } \\
\text { (cllpped at outer Lake } \\
\text { Tahoe basin boundary, } \\
\text { as deflned by TEGIS } \\
\text { coverage BOUND_OUTER). }\end{array}$ & $\begin{array}{l}\text { USGS; derlved from DLG } \\
\text { boundaries files. }\end{array}$ & $1: 24,000$ & $1969-82$ & Polyconic & Digital & $\begin{array}{l}\text { Standard methods } \\
\text { DLG flles. }\end{array}$ & for \\
\hline Do. & do. & do. & do. & do. & do. & do. & \\
\hline Do. & do. & do. & do. & do. & do. & do. & \\
\hline Do. & do. & do. & do. & do. & do. & do. & \\
\hline Do. & do. & do. & do. & do. & do. & do. & \\
\hline Do. & do. & do. & do. & do. & do. & do. & \\
\hline Do. & do. & do. & do. & do. & do. & do. & \\
\hline Do. & do. & do. & do. & do. & do. & do. & \\
\hline Do. & do. & do. & do. & do. & do. & do. & \\
\hline
\end{tabular}

TEGIS coverage

\begin{tabular}{|c|c|c|c|c|c|c|}
\hline $\begin{array}{l}\text { Polygon coverage of } \\
\text { ripar1an-vegetation } \\
\text { zones. }\end{array}$ & $\begin{array}{l}\text { Digltized from USFS riparian- } \\
\text { vegetation maps (Joseph Oden, } \\
\text { written commun., 1991). }\end{array}$ & $1: 24,000$ & 1989 & Polyconic & $\begin{array}{l}\text { Mylar (six } \\
\text { distorted maps } \\
\text { had to be re- } \\
\text { registered). }\end{array}$ & $\begin{array}{l}\text { Thematic lines were } \\
\text { digltized by using } \\
\text { electronic scanner: } \\
\text { feature labels were } \\
\text { assigned interac- } \\
\text { tively by using } \\
\text { ARC/INFO software. }\end{array}$ \\
\hline Do. & do. & do. & do. & do. & do. & do. \\
\hline
\end{tabular}

Do. do. do. do. do. do. do.

TrGIs coverage

\begin{tabular}{|c|c|c|c|c|c|c|}
\hline $\begin{array}{l}\text { L1ne coverage of roads } \\
\text { (cllpped at outer Lake } \\
\text { Tahoe basin boundary, } \\
\text { as defined by TEGIS } \\
\text { coverage BOUND_OUTER). }\end{array}$ & $\begin{array}{l}\text { USGS; derlved from DLG } \\
\text { transportation f1les and } \\
\text { DLG boundaries flles. }\end{array}$ & $1: 24,000$ & $1369-82$ & Polyconic & Digital & $\begin{array}{l}\text { Standard methods for } \\
\text { DLG flles. }\end{array}$ \\
\hline Do. & do. & do. & do. & do. & do. & do. \\
\hline Do. & do. & do. & do. & do. & do. & do. \\
\hline Do. & do. & do. & do. & do. & do. & do. \\
\hline Do. & do. & do. & do. & do. & do. & do. \\
\hline Do. & do. & do. & do. & do. & do. & do. \\
\hline Do. & do. & do. & do. & do. & do. & do. \\
\hline Do. & do. & do. & do. & do. & do. & do. \\
\hline Do. & do. & do. & do. & do. & do. & do. \\
\hline
\end{tabular}




\begin{tabular}{|c|c|c|c|c|c|c|c|c|}
\hline \multirow{4}{*}{$\begin{array}{l}\text { Digitizing } \\
\text { accuracy }\end{array}$} & \multirow{2}{*}{\multicolumn{2}{|c|}{ Verification }} & \multicolumn{6}{|c|}{ Data structure for actribute tables } \\
\hline & & & \multirow{3}{*}{$\begin{array}{l}\text { GIS } \\
\text { data } \\
\text { type }\end{array}$} & \multicolumn{5}{|c|}{ Icem or fleid } \\
\hline & \multirow{2}{*}{$\begin{array}{l}\text { Spatial } \\
\text { data }\end{array}$} & \multirow{2}{*}{$\begin{array}{l}\text { Attribute } \\
\text { data }\end{array}$} & & \multirow[b]{2}{*}{ Names } & \multirow[b]{2}{*}{ Description } & \multicolumn{3}{|c|}{ Specifications } \\
\hline & & & & & & $\begin{array}{l}\text { Input } \\
\text { width } \\
\text { (bytes) }\end{array}$ & $\begin{array}{l}\text { Output } \\
\text { w1dth } \\
\text { (bytes) }\end{array}$ & Type \\
\hline \multicolumn{9}{|c|}{ PISS--Continued } \\
\hline $\begin{array}{l}\text { Standards } \\
\text { for DLG } \\
\text { files. }\end{array}$ & $\begin{array}{l}\text { According to } \\
\text { digltizing } \\
\text { standards for } \\
\text { DLG files. }\end{array}$ & $\begin{array}{l}\text { According to } \\
\text { digitizing } \\
\text { standards for } \\
\text { DLG flles. }\end{array}$ & Polygon & MAJORI & DLG coce & 6 & 6 & Integer. \\
\hline do. & do. & do. & Polygon & MINORI & DLG code & 6 & 6 & Integer. \\
\hline do. & do. & do. & do. & MAJOR2 & do. & 6 & 6 & Do. \\
\hline do. & do. & do. & do. & MINOR2 & do. & 6 & 6 & Do. \\
\hline do. & do. & do. & do. & MAJOR3 & do. & 6 & 6 & Do. \\
\hline do. & do. & do. & do. & MINOR3 & do. & 6 & 6 & Do. \\
\hline do. & do. & do. & do. & MAJOR4 & do. & 6 & 6 & Do. \\
\hline do. & do. & do. & do. & MINOR4 & do. & 6 & 6 & Do. \\
\hline do. & do. & do. & do. & $\begin{array}{l}\text { MAJOR-MINOR_CODE } \\
\text { OI M_CODE. }\end{array}$ & $\begin{array}{l}\text { Comoinat } 10 \text { of MAJOR } \\
\text { and MINOR codes. }\end{array}$ & 48 & 48 & Character. \\
\hline \multicolumn{9}{|l|}{ RIPARTAN_VRG } \\
\hline $\begin{array}{l}\text { RMS range, } \\
0.001- \\
0.008 ; \\
\text { Res range, } \\
0.459- \\
4.595\end{array}$ & $\begin{array}{l}\text { Two or more } \\
\text { veriflcation } \\
\text { piots done by } \\
\text { USFS. }\end{array}$ & $\begin{array}{l}\text { Three or more } \\
\text { veriflcarion } \\
\text { plots done by } \\
\text { USES. }\end{array}$ & Arc & $\begin{array}{l}\text { ARC-CODE or } \\
\text { LK/WB/BSN. }\end{array}$ & $\begin{array}{l}\text { General description } \\
\text { of I1near feacure } \\
\text { (codes: 1, Lake Tahoe } \\
\text { boundary: 2, water- } \\
\text { body boundary; 3, } \\
\text { basin boundary). }\end{array}$ & 2 & 2 & Integer. \\
\hline do. & do. & do. & Polygon & $\begin{array}{l}\text { RIPARIAN-UNIT } \\
\text { Or MAP-UNIT. }\end{array}$ & $\begin{array}{l}\text { Rlparlan-vegetation } \\
\text { code. }\end{array}$ & 2 & 2 & Character. \\
\hline \multicolumn{9}{|l|}{ ROAD } \\
\hline $\begin{array}{l}\text { Standards } \\
\text { for DLG } \\
\text { flles. }\end{array}$ & $\begin{array}{l}\text { According to } \\
\text { dlgitizing } \\
\text { standards for } \\
\text { DLG flles. }\end{array}$ & $\begin{array}{l}\text { According to } \\
\text { dlgitizing } \\
\text { standards for } \\
\text { DLG flles. }\end{array}$ & Arc & MAJORI & DLG cocie & 6 & 6 & Integer. \\
\hline do. & do. & do. & do. & MINORI & do. & 6 & 6 & Do. \\
\hline do. & do. & do. & do. & MAJOR2 & do. & 6 & 6 & Do. \\
\hline do. & do. & do. & do. & MINOR2 & do. & 6 & 6 & Do. \\
\hline do. & do. & do. & do. & MAJOR3 & do. & 6 & 6 & Do. \\
\hline do. & do. & do. & do. & MINOR3 & do. & 6 & 6 & Do. \\
\hline do. & do. & do. & do. & MAJOR4 & do. & 6 & 6 & Do. \\
\hline do. & do. & do. & do. & MINOR4 & do. & 6 & 6 & Do. \\
\hline do. & do. & do. & do. & $\begin{array}{l}\text { MAJOR-MINOR_CODE } \\
\text { or M_CODE. }\end{array}$ & $\begin{array}{l}\text { Combination of MAJOR } \\
\text { and MINOR codes. }\end{array}$ & 48 & 48 & Character. \\
\hline
\end{tabular}




\begin{tabular}{|c|c|c|c|c|c|c|}
\hline \multirow{2}{*}{ Descriprion of coverage } & \multicolumn{5}{|c|}{ Data source } & \multirow{2}{*}{$\begin{array}{l}\text { Diglelzing } \\
\text { merhod }\end{array}$} \\
\hline & Agency and (or) derivacion & Scale & Date & $\begin{array}{c}\text { Map } \\
\text { projection }\end{array}$ & $\begin{array}{l}\text { Media type } \\
\text { and condition, } \\
\text { if applicable }\end{array}$ & \\
\hline & & & & & & TEGIS coverage \\
\hline $\begin{array}{l}\text { Polygon coverage of } \\
\text { soil units. }\end{array}$ & $\begin{array}{l}\text { Derived from SCS soil-survey } \\
\text { maps. }\end{array}$ & $1: 24,000$ & 1974 & Polyconic & $\begin{array}{l}\text { Paper (folded; } \\
\text { dry ironed } \\
\text { before dig- } \\
\text { it } 1 z \text { ing). }\end{array}$ & 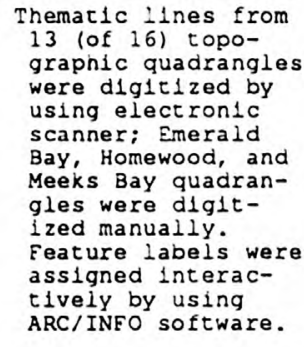 \\
\hline Do. & do. & do. & do. & do. & do. & do. \\
\hline \multirow[t]{2}{*}{ Do. } & do. & do. & do. & do. & do. & do. \\
\hline & & & & & & TEGIS coverage \\
\hline \multirow[t]{2}{*}{$\begin{array}{l}\text { L1ne coverage of Nevada- } \\
\text { Cal1fornia boundary } \\
\text { (clipped at outer Lake } \\
\text { Tahoe basin boundary, } \\
\text { as defined by TEGIS } \\
\text { coverage BOUND_OUTER). }\end{array}$} & $\begin{array}{l}\text { USGS; derived from DLG } \\
\text { boundaries files. }\end{array}$ & $1: 24,000$ & $1969-82$ & Polycontc & Digital & $\begin{array}{l}\text { Standard methods for } \\
\text { DLG flles. }\end{array}$ \\
\hline & & & & & & TRGIS coverage \\
\hline $\begin{array}{l}\text { Polygon coverage of Lake } \\
\text { Tahoe. }\end{array}$ & $\begin{array}{l}\text { USGS; derived from DLG } \\
\text { hydrography flles. }\end{array}$ & $1: 24,000$ & $1969-82$ & Polyconic & Digltal & $\begin{array}{l}\text { Standard methods for } \\
\text { DLG flles. }\end{array}$ \\
\hline Do. & do. & do. & do. & do. & do. & do. \\
\hline Do. & do. & do. & do. & do. & do. & do. \\
\hline Do. & do. & do. & do. & do. & do. & do. \\
\hline Do. & do. & do. & do. & do. & do. & do. \\
\hline Do. & do. & do. & do. & do. & do. & do. \\
\hline Do. & do. & do. & do. & do. & do. & do. \\
\hline Do. & do. & do. & do. & do. & do. & do. \\
\hline \multirow[t]{2}{*}{ Do. } & do. & do. & do. & do. & do. & do. \\
\hline & & & & & & TIGIS coverage \\
\hline $\begin{array}{l}\text { Polygon coverage of } \\
\text { clmber types. }\end{array}$ & $\begin{array}{l}\text { Digitized from USFS timoer- } \\
\text { type maps. }\end{array}$ & $1: 24,000$ & 1979 & Polyconic & $\begin{array}{l}\text { Mylar sepa- } \\
\text { rates (good } \\
\text { to excellent } \\
\text { condltion). }\end{array}$ & $\begin{array}{l}\text { Thematic lines were } \\
\text { dlgltized by using } \\
\text { electronic scanner; } \\
\text { feature labels were } \\
\text { assigned incerac- } \\
\text { tively by using } \\
\text { ARC/INFO software. }\end{array}$ \\
\hline Do. & do. & do. & do. & do. & do. & do. \\
\hline Do. & do. & do. & do. & do. & do. & do. \\
\hline
\end{tabular}




\begin{tabular}{|c|c|c|c|c|c|c|c|c|}
\hline \multirow{4}{*}{$\begin{array}{l}\text { Digitizing } \\
\text { accuracy }\end{array}$} & \multirow{2}{*}{\multicolumn{2}{|c|}{ Verification }} & \multicolumn{6}{|c|}{ Data structure for attribute tables } \\
\hline & & & \multirow{3}{*}{$\begin{array}{l}\text { GIS } \\
\text { data } \\
\text { type }\end{array}$} & \multicolumn{5}{|c|}{ Item or fleld } \\
\hline & \multirow{2}{*}{$\begin{array}{l}\text { Spatial } \\
\text { data }\end{array}$} & \multirow{2}{*}{$\begin{array}{l}\text { Attribuce } \\
\text { data }\end{array}$} & & \multirow[b]{2}{*}{ Names } & \multirow[b]{2}{*}{ Description } & \multicolumn{3}{|c|}{ Specifications } \\
\hline & & & & & & $\begin{array}{l}\text { Input } \\
\text { width } \\
\text { (bytes) }\end{array}$ & $\begin{array}{l}\text { Output } \\
\text { width } \\
\text { (byces) }\end{array}$ & Type \\
\hline \multicolumn{9}{|l|}{ sorI } \\
\hline $\begin{array}{l}\text { RMS range, } \\
0.001- \\
0.009 ; \\
\text { Res range, } \\
0.67-5.7\end{array}$ & $\begin{array}{l}\text { Four linework- } \\
\text { verification } \\
\text { plots done by } \\
\text { USGS and two } \\
\text { done by SCS. }\end{array}$ & $\begin{array}{l}\text { Seven verifi- } \\
\text { cation plots } \\
\text { done by USGS } \\
\text { and two done } \\
\text { by SCS. }\end{array}$ & Arc & $\begin{array}{c}\mathrm{ARC}-\mathrm{CODE} \text { or } \\
\mathrm{LK} / \mathrm{WB} / \mathrm{BSN} .\end{array}$ & $\begin{array}{l}\text { General description } \\
\text { of IInear feature } \\
\text { (codes: 1, Lake Tahoe } \\
\text { boundary; 2, water- } \\
\text { body boundary; } 3 \text {. } \\
\text { basin boundary). }\end{array}$ & 2 & 2 & Integer. \\
\hline do. & do. & do. & Polygon & $\begin{array}{l}\text { MAP-UNIT Or } \\
\text { SOIL-UNIT. }\end{array}$ & scs soil-unit symbol & 4 & 4 & Character. \\
\hline do. & do. & do. & do. & $\begin{array}{l}\text { WATERBODY or } \\
\text { WB-CODE. }\end{array}$ & Water-body code & 6 & 6 & Integer. \\
\hline \multicolumn{9}{|l|}{ STATR_LINR } \\
\hline $\begin{array}{l}\text { Standards } \\
\text { for DLG } \\
\text { flles. }\end{array}$ & $\begin{array}{l}\text { According to } \\
\text { digitizing } \\
\text { standards for } \\
\text { DLG flles. }\end{array}$ & $\begin{array}{l}\text { According to } \\
\text { digitizing } \\
\text { standards for } \\
\text { DLG flies }\end{array}$ & -- & -- & -- & -- & -- & - \\
\hline
\end{tabular}

\begin{tabular}{|c|c|c|c|c|c|c|c|c|}
\hline \multicolumn{9}{|l|}{ TAHOE_LATR } \\
\hline $\begin{array}{l}\text { Standards } \\
\text { for DLG } \\
\text { flles. }\end{array}$ & $\begin{array}{l}\text { According to } \\
\text { dlgltizing } \\
\text { standards for } \\
\text { DLG flles. }\end{array}$ & $\begin{array}{l}\text { According to } \\
\text { digitizing } \\
\text { standards for } \\
\text { DLG flles. }\end{array}$ & Polygon & MAJORI & DLG code & 6 & 6 & Integer. \\
\hline do. & do. & do. & do. & MINOR1 & do. & 6 & 6 & Do. \\
\hline do. & do. & do. & do. & MAJOR2 & do. & 6 & 6 & Do. \\
\hline do. & do. & do. & do. & MINOR2 & do. & 6 & 6 & Do. \\
\hline do. & do. & do. & do. & MAJOR3 & do. & 6 & 6 & Do. \\
\hline do. & do. & do. & do. & MINOR3 & do. & 6 & 6 & Do. \\
\hline do. & do. & do. & do. & MAJOR4 & do. & 6 & 6 & Do. \\
\hline do. & do. & do. & do. & MINOR4 & do. & 6 & 6 & Do. \\
\hline do. & do. & do. & do. & $\begin{array}{l}\text { MAJOR-MINOR_CODE } \\
\text { or M_CODE. }\end{array}$ & $\begin{array}{l}\text { Combination of MAJOR } \\
\text { and MINOR codes. }\end{array}$ & 48 & 48 & Character. \\
\hline \multicolumn{9}{|l|}{ TMABER_TYPE } \\
\hline $\begin{array}{l}\text { RMS range, } \\
0.000- \\
0.006 ; \\
\text { Res range, } \\
0.28-3.8\end{array}$ & $\begin{array}{l}\text { Three Ilnework- } \\
\text { veriflcation } \\
\text { plots done by } \\
\text { USGS; one done } \\
\text { by USFS; elght } \\
\text { done jointly } \\
\text { by USGS and } \\
\text { USES. }\end{array}$ & $\begin{array}{l}\text { Two veriflca- } \\
\text { tion plots } \\
\text { done by USGS; } \\
\text { eignt done } \\
\text { Joint } 1 \text { y by } \\
\text { USGS and USFS. }\end{array}$ & Arc & $\begin{array}{l}\text { ARC-CODE or } \\
\mathrm{LK} / \mathrm{WB} / \mathrm{BSN} \text {. }\end{array}$ & $\begin{array}{l}\text { General description } \\
\text { of l1near feature } \\
\text { (codes: 1, Lake Tahoe } \\
\text { boundary; 2, water- } \\
\text { body boundary; 3, } \\
\text { basin boundary). }\end{array}$ & 2 & 2 & Integer. \\
\hline do. & do. & do. & Polygon & $\begin{array}{l}\text { VEGETATION-UNIT } \\
\text { Or MAP-UNIT. }\end{array}$ & $\begin{array}{l}\text { USFS vegetation } \\
\text { code. }\end{array}$ & 12 & 12 & Character. \\
\hline do. & do. & do. & do. & $\begin{array}{l}\text { WATERBODY or } \\
\text { WB-CODE. }\end{array}$ & Water-body code & 6 & 6 & Integer. \\
\hline
\end{tabular}


Tabl. 20. Detailed cocumentation for Tahoe Environmentai

\begin{tabular}{|c|c|c|c|c|c|c|}
\hline \multirow{2}{*}{ Description of coverage } & \multicolumn{5}{|c|}{ Data source } & \multirow{2}{*}{$\begin{array}{l}\text { D1gitizing } \\
\text { method }\end{array}$} \\
\hline & Agency and (or) derivation & Scale & Date & $\begin{array}{l}\text { Map } \\
\text { projection }\end{array}$ & $\begin{array}{l}\text { Media type } \\
\text { and condition, } \\
\text { if appllcable }\end{array}$ & \\
\hline & & & & & & TEGIS coverage \\
\hline $\begin{array}{l}\text { Polygon coverage of } \\
\text { water-body boundaries } \\
\text { (excluding Lake Tahoe's). }\end{array}$ & $\begin{array}{l}\text { USGS; derived from DLG } \\
\text { hydrography files. }\end{array}$ & $1: 24,000$ & $1969-82$ & Polyconic & Dlgital & $\begin{array}{l}\text { Standard methods for } \\
\text { DLG files. }\end{array}$ \\
\hline Do. & do. & do. & do. & do. & do. & do. \\
\hline Do. & do. & do. & do. & do. & do. & do. \\
\hline Do. & do. & do. & do. & do. & do. & do. \\
\hline Do. & do. & do. & do. & do. & do. & do. \\
\hline Do. & do. & do. & do. & do. & do. & do. \\
\hline Do. & do. & do. & do. & do. & do. & do. \\
\hline Do. & do. & do. & do. & do. & do. & do. \\
\hline Do. & do. & do. & do. & do. & do. & do. \\
\hline Do. & do. & do. & do. & do. & do. & do. \\
\hline Do. & do. & do. & do. & do. & do. & do. \\
\hline
\end{tabular}


Geographic Information System coverages-Continued

\begin{tabular}{|c|c|c|c|c|c|c|c|c|}
\hline \multirow{4}{*}{$\begin{array}{l}\text { Dlgitizing } \\
\text { accuracy }\end{array}$} & \multirow{2}{*}{\multicolumn{2}{|c|}{ Verification }} & \multicolumn{6}{|c|}{ Data structure for attribute tables } \\
\hline & & & \multirow{3}{*}{$\begin{array}{l}\text { GIS } \\
\text { data } \\
\text { type }\end{array}$} & \multicolumn{5}{|c|}{ Item or fleid } \\
\hline & \multirow{2}{*}{$\begin{array}{l}\text { Sparial } \\
\text { data }\end{array}$} & \multirow{2}{*}{$\begin{array}{c}\text { Atcribute } \\
\text { data }\end{array}$} & & \multirow[b]{2}{*}{ Names } & \multirow[b]{2}{*}{ Description } & \multicolumn{3}{|c|}{ Specifications } \\
\hline & & & & & & $\begin{array}{l}\text { Input } \\
\text { width } \\
\text { (byces) }\end{array}$ & $\begin{array}{l}\text { Output } \\
\text { width } \\
\text { (byces) }\end{array}$ & Type \\
\hline \multicolumn{9}{|l|}{ WATER_BODY } \\
\hline $\begin{array}{l}\text { Standards } \\
\text { for DLG } \\
\text { flies. }\end{array}$ & $\begin{array}{l}\text { According to } \\
\text { digitizing } \\
\text { standards for } \\
\text { DLG files. }\end{array}$ & $\begin{array}{l}\text { According to } \\
\text { digitizing } \\
\text { standards for } \\
\text { DLG flies. }\end{array}$ & Arc & $\begin{array}{l}\text { ARC-CODE or } \\
\mathrm{LK} / \mathrm{WB} / \mathrm{BSN} \text {. }\end{array}$ & $\begin{array}{l}\text { General description } \\
\text { of linear feacure } \\
\text { (code: } 3 \text {, basin } \\
\text { boundary). }\end{array}$ & 2 & 2 & Integer. \\
\hline do. & do. & do. & Polygon & MAJORI & DLG code & 6 & 6 & Do. \\
\hline do. & do. & do. & do. & MINORI & co. & 6 & 6 & Do. \\
\hline do. & do. & do. & do. & MAJOR2 & do. & 6 & 6 & Do. \\
\hline do. & do. & do. & do. & MINOR2 & do. & 6 & 6 & Do. \\
\hline do. & do. & do. & do. & MAJOR3 & do. & 6 & 6 & Do. \\
\hline do. & do. & do. & do. & MINOR3 & do. & 6 & 6 & Do. \\
\hline do. & do. & do. & do. & MAJOR4 & do. & 6 & 6 & Do. \\
\hline do. & do. & do. & do. & MINOR4 & do. & 6 & 6 & Do. \\
\hline do. & do. & do. & do. & $\begin{array}{l}\text { WATERBODY or } \\
\text { WB-CODE. }\end{array}$ & Wacer-body code & 6 & 6 & Do. \\
\hline do. & do. & do. & do. & $\begin{array}{l}\text { MAJOR-MINOR_CODE } \\
\text { Or M_CODE. }\end{array}$ & $\begin{array}{l}\text { Comolnation of MAJOR } \\
\text { and MINOR codes. }\end{array}$ & 48 & 48 & Character. \\
\hline
\end{tabular}



